\title{
An Autoantigen-ome from HS-Sultan B-Lymphoblasts Offers a Molecular Map for Investigating Autoimmune Sequelae of COVID-19
}

Julia Y. Wang ${ }^{1 *}$, Wei Zhang ${ }^{2}$, Victor B. Roehrl ${ }^{1}$, Michael W. Roehrl ${ }^{1}$, and Michael H. Roehrl ${ }^{3,4 *}$

${ }^{1}$ Curandis, New York, USA

${ }^{2}$ Department of Gastroenterology, Affiliated Hospital of Guizhou Medical University, Guizhou, China

${ }^{3}$ Department of Pathology and ${ }^{4}$ Human Oncology and Pathogenesis Program, Memorial Sloan Kettering Cancer Center, New York, USA

*Correspondence: julia@curandis.com, roehrlm@mskcc.org

Keywords: Autoantigens, autoantibodies, autoimmunity, SARS-CoV-2, COVID, Epstein-Barr virus 


\section{Abstract}

To understand how COVID-19 may induce autoimmune diseases, we have been compiling an atlas of COVID-autoantigens (autoAgs). Using dermatan sulfate (DS) affinity enrichment of autoantigenic proteins extracted from HS-Sultan lymphoblasts, we identified 362 DS-affinity proteins, of which at least 201 (56\%) are confirmed autoAgs. Comparison with available multi-omic COVID data shows that $315(87 \%)$ of the 362 proteins are affected in SARS-CoV-2 infection via altered expression, interaction with viral components, or modification by phosphorylation or ubiquitination, at least 186 (59\%) of which are known autoAgs. These proteins are associated with gene expression, mRNA processing, mRNA splicing, translation, protein folding, vesicles, and chromosome organization. Numerous nuclear autoAgs were identified, including both classical ANAs and ENAs of systemic autoimmune diseases and unique autoAgs involved in the DNA replication fork, mitotic cell cycle, or telomerase maintenance. We also identified many uncommon autoAgs involved in nucleic acid and peptide biosynthesis and nucleocytoplasmic transport, such as aminoacyl-tRNA synthetases. In addition, this study found autoAgs that potentially interact with multiple SARS-CoV-2 Nsp and Orf components, including CCT/TriC chaperonin, insulin degrading enzyme, platelet-activating factor acetylhydrolase, and the ezrin-moesin-radixin family. Furthermore, B-cell-specific IgM-associated ER complex (including MBZ1, BiP, heat shock proteins, and protein disulfide-isomerases) is enriched by DS-affinity and up-regulated in B-cells of COVID-19 patients, and a similar IgH-associated ER complex was also identified in autoreactive pre-B1 cells in our previous study, which suggests a role of autoreactive B1 cells in COVID-19 that merits further investigation. In summary, this study demonstrates that virally infected cells are characterized by alterations of proteins with propensity to become autoAgs, thereby providing a possible explanation for infection-induced autoimmunity. The COVID autoantigen-ome provides a valuable molecular resource and map for investigation of COVID-related autoimmune sequelae and considerations for vaccine design. 


\section{Introduction}

The novel coronavirus SARS-CoV-2 has caused the worldwide COVID-19 pandemic with hundreds of millions infected and high morbidity and mortality. A significant proportion of patients who have recovered from the acute viral infection of COVID-19 continue to suffer from lingering health problems, so called "long COVID" syndrome. It is yet unknown how long the COVID aftereffects will persist, and more importantly, what the underlying causative mechanisms of long COVID syndrome are. The acute phase of COVID-19 is accompanied by various autoimmune responses, and autoimmune diseases, which tend to be chronic and debilitating, are major concerns of COVID-19 sequelae. To understand how SARS-CoV-2 infection may induce autoimmunity and how diverse the autoimmune disorders could be, we have started to compile a comprehensive atlas of COVID autoantigens (autoAgs) and autoantibodies (autoAbs), the root elements of autoimmunity $[1,2]$.

We have developed a unique DS-affinity enrichment strategy for autoAg discovery [1-8]. We discovered that dermatan sulfate (DS), a glycosaminoglycan that is abundant in skin and soft connective tissues and that is involved in wound healing and tissue repair, has affinity to autoAgs $[3,4]$. Because of this affinity, DS binds autoAgs to form non-covalent DS-autoAg complexes, which transforms non-antigenic singular self-molecules into antigenic non-self-complexes [3]. DS-autoAg complexes are capable of engaging autoreactive B-cell receptors (autoBCRs) via a two-step process: (i) DS-autoAg complexes bind autoBCRs on autoreactive B1-cells via autoAg-autoBCR specificity; (ii) DS enters cells by (DS-autoAg)-autoBCR complex internalization and recruits a cascade of molecules to stimulate autoreactive B1-cells $[3,5]$. In particular, DS recruits GTF2I that is required for IGH gene expression and IgH-associated multiprotein complexes in the endoplasmic reticulum (ER) to facilitate autoAb production [5]. Therefore, any selfmolecule with DS-affinity has a propensity to be transformed by DS into an autoantigenic DS-autoAg complex [5]. Based on this unifying principle of DS-autoAg affinity, we have discovered and catalogued known and putative autoAgs from different cells and organs $[1,2,6-8]$.

Autoantibodies, which target autoAgs, have been found in a significant portion of COVID-19 patients. In a cohort study of 147 hospitalized COVID-19 patients, autoAbs are detected in $~ 50 \%$ of the patients, and antinuclear autoAbs are detected in $\sim 25 \%$ of patients, with the target autoAgs associated with myositis, systemic sclerosis, and connective tissue disease overlap syndromes [9]. In another study of 987 COVID19 patients with life-threatening pneumonia, over 10\% developed autoAbs against interferons, which likely neutralized their ability to block SARS-CoV-2 infection [10]. Although COVID-19 is typically mild or 
asymptomatic in children, multisystem inflammatory syndrome and multiple autoAbs developed in a portion of infected children [11, 12]. In a study of COVID-19 patients with unexplained neurological symptoms, anti-neuronal autoAbs were detected in sera or cerebrospinal fluid of all patients [13]. Antinuclear autoAbs, the most frequently tested autoAbs in clinical screening for autoimmune diseases such as lupus, Sjögren syndrome, scleroderma, or polymyositis, are found in 20-50\% of COVID-19 patients [14-16].

Viral infections have long been regarded as culprits of autoimmune diseases. However, it has remained unclear how infections induce autoimmune diseases. In this study, we investigated HS-Sultan cells, a Bcell lymphoblast line isolated from Burkitt's lymphoma of a 7-year-old boy. HS-Sultan cells are infected with and immortalized by Epstein-Barr virus (EBV) and carry the viral DNA sequence. From the proteome extracts of HS-Sultan cells, we identified a putative DS-affinity autoantigen-ome of 362 proteins, of which 201 are confirmed autoAgs by means of corresponding specific autoAbs reported in the literature. By comparing this autoantigen-ome with proteins affected by SARS-CoV-2 infection derived from multi-omic studies compiled in Coronascape [17-38], we identified 315 DS-affinity proteins and 186 confirmed autoAgs. When host cells are infected, numerous molecules undergo significant changes via altered expression, modification, or degradation. When the infected cells die, these altered molecules are released, and those with DS-affinity may become associated with DS and transform into immunogenic autoAg-DS complexes. This study illustrates that viral infections can profoundly change the host cell autoantigen-ome, result in a large repertoire of potential autoAgs, and may consequently lead to autoimmune disease.

\section{Results and Discussion}

\section{DS-affinity autoantigen-ome of HS-Sultan cells}

HS-Sultan cells were cultured, harvested, and lysed. Total proteins were extracted from lysates and fractionated on DS-Sepharose affinity resins. Proteins with no or weak DS-affinity were removed from the resins with $0.2 \mathrm{M} \mathrm{NaCl}$, and those with intermediate to strong DS-affinity were eluted first with $0.5 \mathrm{M}$ and then with $1.0 \mathrm{M} \mathrm{NaCl}$. Proteins in the DS-affinity fractions were collected, desalted, digested, and sequenced by mass spectrometry. A total of 362 proteins were identified, with the majority present in the $0.5 \mathrm{M} \mathrm{NaCl}$ elution. Proteins that eluted with $1.0 \mathrm{M} \mathrm{NaCl}$ possess very strong DS-affinity and include some 
of the classical nuclear autoAgs, e.g., histones, TOP1, Sm-D3, and 60S acidic ribosomal protein P0. Other proteins with strong DS-affinity include both known autoAgs (vimentin, ATP synthetase ATP5B, and PABPC1) and unknown ones (RPL10A, L15, RPS27A, and mitochondrial single-stranded DNA binding protein SSBP1).

Of the 362 DS-affinity proteins identified from HS-Sultan cells, 201 (55.5\%) are confirmed humoral autoAgs based on prior literature reports of specific autoantibodies (see references in Table 1). These autoAgs and their respective autoantibodies are found in a wide spectrum of autoimmune diseases and cancer. The number of actual autoAgs is likely much greater, as most of the unconfirmed proteins have structural resemblance to known autoAgs. For example, SSBP1 is structurally and functionally similar to the classical lupus autoAg SSB, but it has not formally been identified as an autoAg. As another example, nucleosome assembly protein 1-like 1 and 4 (NAP1L1, NAP1L4) are identified by DS-affinity but unconfirmed as autoAgs, whereas their close relative NAP1L3 has been reported as an autoAg. Due to the structural similarity of many DS-affinity proteins with known autoAgs, it is likely that there are additional yet-to-be discovered (considered putative) autoAgs in this group.

The DS-affinity autoantigen-ome, which includes confirmed and putative autoAgs, is not a random collection of proteins but functionally highly connected. As shown by protein-protein interaction analysis, the DS-affinity autoantigen-ome possesses significantly more interactions than expected $(3,105$ interactions at high confidence level vs. 1,249 expected; PPI enrichment p-value <1.0E-16). Based on Gene Ontology (GO) biological process analysis, the DS-affinity autoantigen-ome of HS-Sultan cells is significantly associated with RNA slicing, translation, peptide biosynthesis, protein folding, proteolysis, biosynthesis and metabolism of nucleobase-containing small molecules (e.g., nucleobase, nucleoside, and nucleotide phosphate), cytoskeleton organization, and chromosome organization (Fig. 1). Pathway and process enrichment analysis reveals that it is also significantly associated with neutrophil degranulation, nucleocytoplasmic transport, kinase maturation complex, metabolic reprogramming, and IL-12 mediated signaling (Fig. 2A).

The DS-affinity autoantigen-ome is dominated by several families of proteins. There are 24 proteasomal proteins, 22 spliceosome proteins, 14 hnRNPs, 13 aminoacyl-tRNA synthases (ligases), 13 translation initiation factors subunits, 12 ribosomal proteins, 10 heat shock proteins, 9 actin and actin-related proteins, 9 tubulins, 8 histones, 8 snRNPs, 7 T-complex proteins (CCT/TriC), 6 elongation factor subunits, 
and 6 14-3-3 proteins. The majority of the proteins in these families have been reported as autoAgs (Table 1). For example, all hnRNP and snRNP proteins identified by DS-affinity in this study are among the bestknown nuclear autoAgs. Interestingly, autoAgs included in clinical diagnostic autoimmune disease ANA screening panels, such as SSB (lupus La), SNRPD1 (Sm D1), SNRPD3 (Sm D3), histones, and TOP1, are all identified in this study by DS-affinity enrichment from HS-Sultan cells.

In addition to proteins, such as ribosomal and ribonucleoproteins, that can be consistently identified from a variety of cell types, HS-Sultan B lymphoblast cells give rise to a large number of unique DS-affinity protein categories. In particular, many proteins associated with biomolecule biosynthesis are identified. Among them are proteins involved in inosine monophosphate and purine nucleotide biosynthesis (ATIC, GART, HPRT1, PAICS, PFAS, PPAT, SHMT1), amino acid biosynthesis (CS, IDH3A, PHGDH, PGAM1, PGAM2, PSPH), and carbohydrate biosynthesis and catabolic processes (ALDOA, ALDOC, ENO2, G6PD, GBE1, LDHA, TALDO1). There are also proteins involved in protein transport (ARF1, CSE1L, GDI1, GDI2, HMGB1, IPO5, KPNA2, RAB7A, RANBP1, RANBP6, SRP14, TNPO1, XPOT), dephosphorylation (NSF1C, PPP1R7, PPP2R1A, SET, SWAP70), and ubiquitination and de-ubiquitination (OTUB1, SHMT2, UBA1, UBA6, UBE2K, USP5). 17 of these 44 proteins are currently known autoAgs, while the remainder await further investigation. Overall, HS-Sultan cells appear to be especially rich in biosynthetic protein machinery, which may explain the rapid proliferation of these cells in Burkitt lymphoma.

Thirteen aminoacyl-tRNA synthetases were identified by DS-affinity from HS-Sultan cells, including AARS, DARS, ERPS, FARSB, GARS, HARS, KARS, NARS, PUS1, SARS, VARS, WARS, and YARS. Ten of these are already known autoAgs (Table 1), although we suspect that the remainder will also likely be autoAgs. This group of proteins are the culprits of antisynthetase syndrome, an autoimmune disease characterized by autoantibodies against one or multiple tRNA synthetases. Antisynthetase syndrome is a chronic disorder that can affect many parts of the body, with common symptoms including myositis, interstitial lung disease, polyarthritis, skin thickening and cracking of fingers and toes, or Raynaud disease. Antisynthetase syndrome has been reported in a case report of COVID-19 interstitial lung disease [39].

HS-Sultan cells are B lymphoblasts immortalized by Epstein-Barr virus (EBV) infection and carry viral DNA sequences. Using DS-affinity, we identified numerous proteins involved in DNA repair and the mitotic cell cycle, including CLTC, DCTN2, MCM2, MCM3, MCM4, MCM6, NSF1C, PNCA, PPAT, and SUGT1. Using DSaffinity, we also identified many proteins associated with telomerase maintenance, including TCP1, CCT2, 
CCT4, CCT5, CCT7, HNRNPA1, HNRPNA2B1, HNRNPC, HNRNPD, HNRNPU, HSP90AA1, HSP90AB1, PARP1, PTGES3, and XRCC5. Telomerase maintenance, which counteracts DNA damage response, cell cycle arrest, and apoptosis, is crucial for immortalization of cells with unlimited proliferative potential. Of these 25 proteins, 19 are known autoAgs, which indicates that proteins involved in telomerase maintenance, DNA repair, and cell cycle may be affected by EBV infection and become autoantigenic.

\section{DS-affinity autoantigen-ome related to SARS-CoV-2 infection}

To find out whether DS-affinity autoAgs are affected in SARS-CoV-2 infection, we conducted similarity searches with currently available multi-omic COVID-19 data compiled in Coronascape (as of 02/22/2021) [17-38]. Among our 362 DS-affinity proteins, 315 (87.0\%) are affected by SARS-CoV-2 infection (Table 1). Of these 315 proteins, 209 are up-regulated and 248 are down-regulated at protein and/or mRNA levels, and 95 are in the interactomes of individual SARS-CoV-2 viral proteins. Because the COVID-19 multi-omics data have been obtained with various methods from different infected cells or patients, there are proteins found up-regulated in some studies but down-regulated in other studies, but nevertheless, these proteins are affected by the infection and thus considered COVID-affected in our analysis (Supplemental Table 1). Of the 315 COVID-affected DS-affinity proteins, 186 (59.0\%) are thus far confirmed autoAgs, while 129 are putative autoAgs (Table 1).

The COVID-affected DS-affinity proteins are highly connected (Fig. 3). By STRING analysis, these 315 proteins exhibit 2,507 interactions at high confidence level, which is significantly higher than randomly expected (1,002 interactions) with PPI enrichment $p$-value $<1.0 \mathrm{E}-16$. The proteins are primarily associated with RNA and mRNA processing, translation, vesicles, and vesicle-mediated transport (Fig. 3), which is consistent with our findings in other cell types [1, 2, 8]. In addition, these proteins are enriched in protein folding, peptide biosynthesis, granulocyte activation, emerin complex, IL-12 mediated signaling pathway, CDC5L complex, and metabolic reprogramming (Fig. 2B).

Twenty-one COVID-affected DS-affinity proteins are associated with mRNA splicing, including heterogenous nuclear ribonucleoproteins (hnRNP A1, A2B1, $A 3, A B, C, D L, F, H 1, K, Q, R$, and U), small nuclear ribonucleoproteins (SNRNP70, SNRPA, SNRPE, SNRPD1, SNRRPD2, SNRPD3), and splicing factors (SRSF1, SRSF2, SFPQ), all of which are well-known autoAgs. 
Phosphorylation and ubiquitination changes induced by SARS-CoV-2 infection are posttranslational molecular alterations that may transform native proteins into potential autoAgs (Fig. 4), which is consistent with our previous findings [2]. Phosphorylation changes affected 80 COVID-altered DS-affinity proteins, including 8 hnRNPs, 4 initiation factors (EIF3A, 3B, 5), 3 elongation factors, 3 replication licensing factors (MCM2, 3, 4), SSB, XRCC6, and GTF2I. These phosphoproteins are associated with mRNA splicing, translation, telomere maintenance, DNA conformation change, and pre-replicative complex assembly. Ubiquitination changes affected 101 COVID-altered DS-affinity proteins, including 8 heat shock proteins, 5 initiation factors (EIF3E, 3F, 3I, 4A1, 5A), 4 CCT units, 4 14-3-3 proteins, 3 elongation factors, 3 histones, and 2 MCMS. These ubiquitinated proteins are associated with the nucleobase-containing compound catabolic process, RNA metabolism, cellular response to stress, prefoldin mediated transfer of substrate to $\mathrm{CCT} /$ TriC, and axon guidance.

\section{AutoAgs that interact with SARS-CoV-2 components}

There are 95 DS-affinity proteins found in the interactomes of various SARS-CoV-2 proteins (Fig. 5), meaning that these proteins can interact directly or indirectly with viral components. They appear to be intimately involved in protein metabolism, including 17 proteins related to peptide biosynthesis, 25 related to protein folding, 29 related to protein localization, and 22 related to proteolysis. In addition, these proteins are associated with the symbiont viral process, translational initiation, protein deubiquitination, protein stabilization, and posttranslational protein modification.

The chaperonin-containing T-complex (CCT), also known as T-complex protein ring complex (TriC), is the chaperonin of eukaryotic cells. The human CCT/TriC complex is a two-ring barrel-like complex formed by 8 similar but distinct subunits. Remarkably, all 8 CCT subunits are identified by DS-affinity, and 7 of them are found in the SARS-CoV-2 interactomes: CCT2 (interacts with Nsp12, Orf8, Orf9b, Orf10), CCT5 (with Nsp1, Nsp12, Orf8, Orf10), CCT6A (with Nsp1, Nsp12, Orf10), CCT8 (with Nsp1, Nsp12, Nsp14), CCT3 (with Orf8, Orf10), TCP1 (with Orf10), and CCT7 (with Orf10). In total, 6 SARS-CoV-2 proteins interact with the host cell CCT chaperonin, with Orf10 interacting with 6 CCT subunits (Fig. 5). Furthermore, CCT subunits and PDFN2 (prefoldin subunit 2) are found together in the interactomes of Orf10, Nsp12, and Nsp15. CCTs assist the folding of proteins upon ATP hydrolysis, aiding in the folding of $\sim 10 \%$ of the proteome. PDFN2 binds the nascent polypeptide chain and promotes folding in an environment in which there are many competing pathways for nonnative proteins. Therefore, these findings suggest that SARS-CoV-2 exploits CCT complex and PDFN2 to ensure competitive folding of nonnative viral proteins in the host cells. 
In addition to CCT/TriC, heat shock proteins (HSPs) are another group of chaperones frequently identified with DS-affinity. Ten HSPs are identified in this study, including HSPA4, HSPA5, HSPA8, HSPA9, HSPD1, HSPH1, HSP90AA1, HSP90AA2, HSP90AB1, and HSP9B1. All 10 are known autoAgs (Table 1). HSP8 interacts with Nsp2 and Nsp12. HSP90B1 (endoplasmin) interacts with Orf3a and Orf9c. HSPA9 interacts with N protein. HSP90AB1 interacts with Nsp12. Most strikingly, HSPA5 (GRP78, BiP) interacts with 9 SARS-CoV2 proteins, including S, E, M, Nsp2, Nsp4, Nsp6, Orf3a, Orf7a, and Orf7b. In addition, CDC37 (Hsp90 cochaperone, hsp90 chaperone protein kinase-targeting) interacts with Nsp16. ST13 (Hsc70-interacting protein) interacts with 5 SARS-CoV-2 proteins (Nsp12, Orf3b, Orf6, Orf8, and Orf10). STIP1 (stress induced phosphoprotein 1, HSP90AA1 co-chaperone) interacts with 4 viral proteins (Nsp12, Orf3a, Orf8, and E).

The replication machinery of SARS-CoV-2 interacts with 41 different DS-affinity proteins. Nsp12, an RNAdependent RNA polymerase and the central component of the replication machinery, interacts with the largest number (i.e., 22) of DS-affinity proteins (Fig. 5). Its cofactor Nsp7 interacts with 12 proteins and Nsp8 interacts with only one. The replication machine also includes a helicase (Nsp13), 2 ribonucleases (Nsp14 and Nsp15), 2 RNA-cap methyltransferases (Nsp14, Nsp16), and cofactor Nsp10. Nsp15 interacts with 10 DS-affinity proteins, Nsp16 interacts with 8 proteins, Nsp13 interacts with SRP14 and RDX, Nsp14 interacts with IDE and CCT8, and Nsp10 interacts with PSMA3. Nsp12-interacting DS-affinity proteins are strongly associated with protein folding, particularly prefoldin mediated transfer of substrates to CCT complex and cooperation of prefoldin and CCT in protein folding (Fig. 5). Nsp15-interacting proteins are also associated with prefoldin-mediated substrate transfer to CCT. DS-affinity proteins interacting with other individual viral replication components have no clear biological associations.

Orf3b of SARS-CoV-2 interacts with 12 DS-affinity proteins, including 6 proteasomal proteins, 3 protein disulfide-isomerases, IDE, ST13, and PAFAH1B3 (Fig. 5). Orf3a interacts with 7 proteins, including STIP1 (stress-induced-phosphoprotein 1) and 6 ER proteins (HSPA5, HSP90B1, CNPY2, ERO1L, PRKCSH, and PDIA3). CANPY2 prevents MIR-mediated MRLC ubiquitination and its subsequent proteasomal degradation. ERO1L (or ERO1A) is an oxidoreductase in disulfide bond formation in the ER. PRKCSH (glucosidase II subunit beta) cleaves sequentially the 2 innermost glucose residues from the $\mathrm{GlC}_{2} \mathrm{Man}_{9} \mathrm{GlcNAC}_{2}$ oligosaccharide precursor of immature glycoproteins. Based on the normal functions of their interacting proteins, Orf3a and Orf3b appear to affect host stress response and protein processing in the ER. 
The S protein of SARS-CoV-2 is found to interact with HSPA5 (GRP78/BiP), PRKCSH, PRS27A (ubiquitin-40S ribosomal protein), MSN, and EZR. EZR and MSN are members of the ezrin-moesin-radixin (ERM) family, and its third member RDX is found to interact with Nsp13 of the virus. Moesin is localized to filopodia and other membranous protrusions that are important for cell-cell recognition, and ERM proteins connect the plasma membranes to the actin-based cytoskeleton. Actin and cytoskeleton proteins have been consistently found to be altered in SARS-CoV-2 infection in our previous studies [1, 2], and this finding suggests that ERM proteins facilitate the viral trafficking from host cell membrane to the cytoskeleton. All three ERM proteins are confirmed autoAgs.

Nsp1 is a major virulence factor of coronavirus. COVID-19 patients with autoantibodies are found to have higher levels of antibodies against SARS-CoV-2 Nsp1 protein [9]. Nsp1 has been reported to hijack the host $40 \mathrm{~S}$ ribosome by inserting its $C$ terminus into the mRNA entry tunnel, which effectively blocks RGIdependent innate immune responses [40]. In this study, we found that Nsp1 interacts with 7 subunits of the translation initiation factor 3 complex (EIF3 A, B, C, E, F, I, L). EIF3 complex binds the 40S ribosome and serves as a scaffold for other initiation factors, auxiliary factors, and mRNA. Hence, our study extends previous reported activities of Nsp1 and shows that Nsp1 engages both the 40S ribosome and EIF3 to manipulate host protein translation.

A few interesting SARS-CoV-2-interacting DS-affinity proteins may provide clues to potential COVID-19 symptoms. PAFAH1B3 is a catalytic unit of the platelet-activating factor acetylhydrolase complex and plays important roles in platelet activation regulation and brain development, and it interacts with Nsp12, Nsp5, and Orf3b. Another subunit, PAFAH1B2, is altered in SARS-CoV-2 infection. Both this and our previous studies [2] have identified PAFAH1B2 and B3 as potential COVID-altered autoAgs, and their roles in COVID coagulopathy merit further investigation.

IDE (insulin degrading enzyme) is a ubiquitously expressed metalloprotease that degrades insulin, beta amyloid, and others. IDE interacts with 6 SARS-CoV-2 proteins (Nsp4, Nsp12, Nsp14, Nsp15, Nsp16, and Orf3b). Although its role in COVID remains unknown, IDE has been partially characterized in other viral infections. It is one of the host factors of hepatitis C virus [41], and it degrades HIV-1 p6 Gap protein and regulates virus replication in an Env-dependent manner [42]. In varicella zoster virus infection, the viral gE protein precursor associates with IDE, HSPA5, HSPA8, HSPD1, and PPIA in the ER of infected cells [43]. 
Interestingly, this group of ER proteins is also identified in this study, although we identified PPIB instead of PPIA. Although IDE has not yet formally been described as an autoAg, we have identified IDE in this and another study [2], and its importance for COVID-19 and autoimmunity merits further investigation.

\section{DS-affinity and B-cell-specific IgH-ER complex}

Because HS-Sultan cells are derived from B lymphoblasts infected by Epstein-Barr virus, we compared the DS-affinity autoantigen-ome with single-cell mRNA expression profiles of B-cells from 7 patients hospitalized with COVID-19 [23]. We identified 39 DS-affinity proteins that are up-regulated at mRNA level in COVID B-cells, which include 7 heat shock proteins, 6 proteasomal proteins, 4 protein disulfideisomerases, HDGF (heparin binding growth factor), CLIC1, CPNE3, SND1, TALDO1, TCL1A, and others (Fig. 6). These up-regulated proteins are primarily associated with protein processing in the ER and the proteasome. We also identified 21 DS-affinity proteins that are down-regulated in COVID B-cells, including 4 translation elongation factors, 2 translation initiation factors, 2 hnRNPs, 2 aminoacyl-tRNA synthetases, NACA, NAP1L1, and PABPC1. These down-regulated proteins are primarily associated with gene expression (Fig. 6).

In particular, MZB1 (marginal zone B- and B1-cell-specific protein) is found up-regulated in B-cells from 5 of the 7 COVID-19 patients. MZB1 is a B-cell-specific ER-localized protein that is most abundantly expressed in marginal zone B-cells and B1-cells [44]. These cells are also termed innate-like B cells. They differ from follicular B-cells by their attenuated $\mathrm{Ca}^{2+}$ mobilization, fast antibody secretion, and increased cell adhesion. MZB1 plays important roles in humoral immunity and helps diversify peripheral B-cell functions by regulating calcium stores, antibody secretion, and integrin activation. MZB1 mRNA expression was found increased by $>2$-fold in B-cells of SLE patients with active disease [45]. High MZB1 gene expression predicted adverse prognosis in chronic lymphocytic leukemia, follicular lymphoma, and diffuse large B-cell lymphoma [46]. High prevalence of MZB1-positive plasma B-cells in tissue fibrosis was found in human lung and skin fibrosis, and MZB1 levels correlated positively with tissue IgG and negatively with diffusion capacity of the lung [47].

MZB1 is part of a B-cell-specific ER chaperone complex, associates with IgM heavy chain (IgH) and HSP90B1 (Grp94), and augments IgM assembly and secretion [48]. MZB1 is also found to augment the function of PDIA3 (ERp57) [44]. In this study, MZB1, HSP90B1, HSPA5 (Grp78, BiP), PDIA4, PDIA6, and CALR are found jointly up-regulated in the B-cells of the same 5 COVID-19 patients. This finding suggests that 
these 6 proteins are in the same IgH-associated ER complex. In addition, several other up-regulated ER proteins are identified, including HSP90AB1, HSPD1, HSPA8, PDIA3, P4HB, and PPIB.

Interestingly, in our study of murine pre-B1 lymphoblasts, we also found that DS interacts with the same IgH-associated multiprotein complex in the ER [5]. In addition, we had observed that DS interacts directly with GTF2I in murine pre-B1 cells, and GTF2I is also identified by DS-affinity in human B lymphoblast HSSultan cells in this study. GTF2I is a required gene transcription factor at the IgH gene locus. Pre-B1 cells, which express precursor B-cell receptors (preBCRs) that are polyreactive and autoreactive, are a critical check point in the development of mature autoreactive B cells. The Ig heavy chain $(\operatorname{IgH})$ repertoire of autoantibodies is determined at the pre-B stage. Our previous findings from pre-B1 cells suggested that DS is a potential master regulator of IgH at both the gene and protein expression levels, i.e., DS recruits GTFI for $\mathrm{lgH}$ gene expression and engages IgH-associated ER complex for autoantibody production. The findings from this study provide further support for a key role of DS in regulating autoantibody production and autoreactive B1-cell development. Furthermore, the finding from B-cells of COVID-19 patients point to a potential significance of autoreactive B1 cells in COVID-induced autoimmunity.

\section{Conclusion}

Exploiting the affinity between autoAgs and DS glycosaminoglycan, we identified 362 DS-affinity proteins from EBV-immortalized HS-Sultan cells. 201 of these DS-affinity proteins are already known autoAgs in a wide variety of autoimmune diseases and cancer. Of the 362, 315 DS-affinity proteins are affected by SARS-CoV-2 infection, and 186 COVID-affected DS-affinity proteins are known autoAgs. These COVIDaltered proteins are largely affected by phosphorylation, ubiquitination, or interaction with viral protein components. They are associated with gene expression, mRNA processing, mRNA splicing, translation, protein folding, DNA replication fork, telomerase maintenance, chromosome organization, biosynthesis and catabolism of nucleobase-containing molecules and proteins, vesicles, and nucleocytoplasmic transport. CCT/TriC chaperonin, insulin degrading enzyme, and platelet-activating factor acetylhydrolase are found in the interactomes of multiple viral Nsp and Orf proteins. By integrating DS-affinity autoAgs with multi-omic data from COVID, our study suggests that viral infections can cause significant proteomic alterations, give rise to a diverse pool of autoAgs, and may lead to infection-induced autoimmune diseases. The COVID autoantigen-ome provided in this paper may serve as a molecular map and resource 
for investigating autoimmune phenomena of SARS-CoV-2 infection and its long-term sequelae. Understanding immunogenic proteins of COVID may also enhance vaccine target design.

\section{Materials and Methods}

\section{HS-Sultan cell culture}

The human B lymphoblast HS-Sultan cell line was obtained from the ATCC (Manassas, VA) and cultured in complete RPMI-1640 medium. The growth medium was supplemented with $10 \%$ fetal bovine serum and a penicillin-streptomycin-glutamine mixture (Thermo Fisher). The cells were grown at $37{ }^{\circ} \mathrm{C}$ in a $\mathrm{CO}_{2}$ incubator, and about 300 million cells were harvested for the study.

\section{Protein extraction}

Protein extraction was performed as previously described [4]. In brief, HS-Sultan cells were lysed with 50 $\mathrm{mM}$ phosphate buffer ( $\mathrm{pH}$ 7.4) containing the Roche Complete Mini protease inhibitor cocktail and then homogenized on ice with a microprobe sonicator until the turbid mixture turned nearly clear with no visible cells left. The homogenate was centrifuged at $10,000 \mathrm{~g}$ at $4{ }^{\circ} \mathrm{C}$ for $20 \mathrm{~min}$, and the total protein extract in the supernatant was collected. Protein concentration was measured by absorbance at $280 \mathrm{~nm}$ using a NanoDrop UV-Vis spectrometer (Thermo Fisher).

\section{DS-Sepharose resin preparation}

The DS-affinity resins were synthesized as previously described [4, 8]. In brief, $20 \mathrm{ml}$ of EAH Sepharose 4B resins (GE Healthcare Life Sciences) were washed with distilled water three times and mixed with $100 \mathrm{mg}$ of DS (Sigma-Aldrich) in $10 \mathrm{ml}$ of $0.1 \mathrm{M}$ MES buffer, pH 5.0. About $100 \mathrm{mg}$ of $\mathrm{N}$-(3-dimethylaminopropyl)$\mathrm{N}^{\prime}$-ethylcarbodiimide hydrochloride (Sigma-Aldrich) powder was added, and another $100 \mathrm{mg}$ was added after $8 \mathrm{~h}$ of reaction. The reaction proceeded by mixing on a rocker at $25^{\circ} \mathrm{C}$ for $16 \mathrm{~h}$. The coupled resins were washed with water and equilibrated with $0.5 \mathrm{M} \mathrm{NaCl}$ in $0.1 \mathrm{M}$ acetate $(\mathrm{pH} 5.0)$ and $0.5 \mathrm{M} \mathrm{NaCl}$ in 0.1 M Tris (pH 8.0).

\section{DS-affinity fractionation}

The total proteomes extracted from HS-Sultan cells were fractionated in a DS-Sepharose column in a manner similar to previously described [4]. About $40 \mathrm{mg}$ of proteins in $40 \mathrm{ml}$ of $10 \mathrm{mM}$ phosphate buffer 
( $\mathrm{pH} 7.4$; buffer A) were loaded onto the DS-affinity column at a rate of $1 \mathrm{ml} / \mathrm{min}$. Unbound and weakly bound proteins were removed with $60 \mathrm{ml}$ of buffer $\mathrm{A}$ and then $40 \mathrm{ml}$ of $0.2 \mathrm{M} \mathrm{NaCl}$ in buffer $\mathrm{A}$. The remaining bound proteins were eluted in steps with $40 \mathrm{ml} 0.5 \mathrm{M} \mathrm{NaCl}$ and then with $40 \mathrm{ml} 1.0 \mathrm{M} \mathrm{NaCl}$ in buffer A. Fractions were desalted and concentrated with 5-kDa cut-off Vivaspin centrifugal filters (Sartorius). Fractionated proteins were separated in 1-D SDS-PAGE in 4-12\% Bis-Tris gels, and the gel lanes were divided into two or three sections for mass spectrometric sequencing.

\section{Mass spectrometry sequencing}

Protein sequencing was performed at the Taplin Biological Mass Spectrometry Facility at Harvard Medical School. Proteins in gels were digested with sequencing-grade trypsin (Promega) at $4{ }^{\circ} \mathrm{C}$ for $45 \mathrm{~min}$. Tryptic peptides were separated in a nano-scale $\mathrm{C}_{18}$ HPLC capillary column and analyzed in an LTQ linear ion-trap mass spectrometer (Thermo Fisher). Peptide sequences and protein identities were assigned by matching the measured fragmentation pattern with proteins or translated nucleotide databases using Sequest. All data were manually inspected. Proteins with $\geq 2$ peptide matches were considered positively identified.

\section{COVID data comparison}

DS-affinity proteins were compared with currently available COVID-19 multi-omic data compiled in the Coronascape database (as of 02/22/2021) [17-38]. These data have been obtained with proteomics, phosphoproteomics, interactome, ubiquitome, and RNA-seq techniques. Up- and down-regulated proteins or genes were identified by comparing cells infected vs. uninfected by SARS-CoV-2 or COVID-19 patients vs. healthy controls. Similarity searches were conducted to identify DS-affinity proteins that are up- and/or down-regulated in viral infection at any omic level.

\section{Protein network analysis}

Protein-protein interactions were analyzed by STRING [49]. Interactions include both direct physical interaction and indirect functional associations, which are derived from genomic context predictions, high-throughput lab experiments, co-expression, automated text mining, and previous knowledge in databases. Each interaction is annotated with a confidence score from 0 to 1 , with 1 being the highest, indicating the likelihood of an interaction to be true. Pathways and processes enrichment were analyzed with Metascape [17], which utilize various ontology sources such as KEGG Pathway, GO Biological Process, Reactome Gene Sets, Canonical Pathways, CORUM, TRRUST, and DiGenBase. All genes in the genome were used as the enrichment background. Terms with a $p$-value $<0.01$, a minimum count of 3 , and an 
bioRxiv preprint doi: https://doi.org/10.1101/2021.04.05.438500; this version posted April 6, 2021. The copyright holder for this preprint (which was not certified by peer review) is the author/funder, who has granted bioRxiv a license to display the preprint in perpetuity. It is made available under aCC-BY 4.0 International license.

enrichment factor (ratio between the observed counts and the counts expected by chance) $>1.5$ were collected and grouped into clusters based on their membership similarities. The most statistically significant term within a cluster was chosen to represent the cluster.

\section{Autoantigen literature text mining}

Every DS-affinity protein identified in this study was searched for specific autoantibodies reported in the PubMed literature. Search keywords included the MeSH keyword "autoantibodies", the protein name or its gene symbol, or alternative names and symbols. Only proteins for which specific autoantibodies are reported in PubMed-listed journal articles were considered "confirmed" autoAgs in this study. 


\section{Acknowledgements}

We thank Jung-hyun Rho for technical assistance with experiments. We thank Ross Tomaino and the Taplin Biological Mass Spectrometry facility of Harvard Medical School for expert service with protein sequencing.

\section{Funding Statement}

This work was partially supported by Curandis, the US NIH, and a Cycle for Survival Innovation Grant (to MHR). MHR acknowledges NIH/NCI R21 CA251992 and MSKCC Cancer Center Support Grant P30 CA008748. The funding bodies were not involved in the design of the study and the collection, analysis, and interpretation of data.

\section{Competing interest statement}

JYW is the founder and Chief Scientific Officer of Curandis. WZ was supported by the NIH and declares no competing interests. MWR and VBR are volunteers of Curandis. MHR is a member of the Scientific Advisory Boards of Trans-Hit, Proscia, and Universal DX, but these companies have no relation to the study.

\section{Authors' contributions}

JYW directed the study and wrote the manuscript. WZ performed part of the experiments. MWR and VBR assisted with data analysis and manuscript preparation. MHR consulted on the study and edited the manuscript. All authors have approved the manuscript. 


\section{References}

1. Wang JY, Zhang W, Roehrl MW, Roehrl VB, Roehrl MH. An Autoantigen Atlas from Human Lung HFL1 Cells Offers Clues to Neurological and Diverse Autoimmune Manifestations of COVID-19. bioRxiv. 2021:2021.01.24.427965. doi: 10.1101/2021.01.24.427965.

2. Wang JY, Zhang W, Roehrl MW, Roehrl VB, Roehrl MH. An Autoantigen Profile of Human A549 Lung Cells Reveals Viral and Host Etiologic Molecular Attributes of Autoimmunity in COVID-19. bioRxiv. 2021:2021.02.21.432171. doi: 10.1101/2021.02.21.432171.

3. Wang JY, Lee J, Yan M, Rho JH, Roehrl MH. Dermatan sulfate interacts with dead cells and regulates CD5(+) B-cell fate: implications for a key role in autoimmunity. Am J Pathol. 2011;178(5):216876. doi: 10.1016/j.ajpath.2011.01.028. PubMed PMID: 21514431; PubMed Central PMCID: PMCPMC3081202.

4. Rho JH, Zhang $\mathrm{W}$, Murali $\mathrm{M}$, Roehrl MH, Wang JY. Human proteins with affinity for dermatan sulfate have the propensity to become autoantigens. Am J Pathol. 2011;178(5):2177-90. doi: 10.1016/j.ajpath.2011.01.031. PubMed PMID: 21514432; PubMed Central PMCID: PMCPMC3081203.

5. Lee J, Rho J-h, Roehrl MH, Wang JY. Dermatan Sulfate Is a Potential Master Regulator of IgH via Interactions with Pre-BCR, GTF2I, and BiP ER Complex in Pre-B Lymphoblasts. bioRxiv. 2021:2021.01.18.427153. doi: 10.1101/2021.01.18.427153.

6. Zhang $\mathrm{W}$, Rho JH, Roehrl MH, Wang JY. A comprehensive autoantigen-ome of autoimmune liver diseases identified from dermatan sulfate affinity enrichment of liver tissue proteins. BMC immunology. 2019;20(1):21. doi: 10.1186/s12865-019-0304-1. PubMed PMID: 31242852; PubMed Central PMCID: PMCPMC6595630.

7. Zhang W, Rho JH, Roehrl MW, Roehrl MH, Wang JY. A repertoire of 124 potential autoantigens for autoimmune kidney diseases identified by dermatan sulfate affinity enrichment of kidney tissue proteins. PloS one. 2019;14(6):e0219018. doi: 10.1371/journal.pone.0219018. PubMed PMID: 31237920; PubMed Central PMCID: PMCPMC6592568.

8. Wang JY, Zhang W, Rho JH, Roehrl MW, Roehrl MH. A proteomic repertoire of autoantigens identified from the classic autoantibody clinical test substrate HEp-2 cells. Clinical proteomics. 2020;17:35. Epub 2020/09/26. doi: 10.1186/s12014-020-09298-3. PubMed PMID: 32973414; PubMed Central PMCID: PMCPMC7507713.

9. Chang SE, Feng A, Meng W, Apostolidis SA, Mack E, Artandi M, et al. New-Onset IgG Autoantibodies in Hospitalized Patients with COVID-19. medRxiv : the preprint server for health sciences. 2021. Epub 2021/02/04. doi: 10.1101/2021.01.27.21250559. PubMed PMID: 33532787; PubMed Central PMCID: PMCPMC7852238.

10. Bastard P, Rosen LB, Zhang Q, Michailidis E, Hoffmann HH, Zhang Y, et al. Autoantibodies against type I IFNs in patients with life-threatening COVID-19. Science (New York, NY). 2020;370(6515). Epub 2020/09/26. doi: 10.1126/science.abd4585. PubMed PMID: 32972996.

11. Consiglio CR, Cotugno N, Sardh F, Pou C, Amodio D, Rodriguez L, et al. The Immunology of Multisystem Inflammatory Syndrome in Children with COVID-19. Cell. 2020;183(4):968-81.e7. Epub 2020/09/24. doi: 10.1016/j.cell.2020.09.016. PubMed PMID: 32966765; PubMed Central PMCID: PMCPMC7474869.

12. Gruber CN, Patel RS, Trachtman R, Lepow L, Amanat F, Krammer F, et al. Mapping Systemic Inflammation and Antibody Responses in Multisystem Inflammatory Syndrome in Children (MIS-C). Cell. 2020;183(4):982-95.e14. Epub 2020/09/30. doi: 10.1016/j.cell.2020.09.034. PubMed PMID: 32991843; PubMed Central PMCID: PMCPMC7489877.

13. Franke C, Ferse C, Kreye J, Reincke SM, Sanchez-Sendin E, Rocco A, et al. High frequency of cerebrospinal fluid autoantibodies in COVID-19 patients with neurological symptoms. Brain, behavior, and 
immunity. 2020. Epub 2020/12/29. doi: 10.1016/j.bbi.2020.12.022. PubMed PMID: 33359380; PubMed Central PMCID: PMCPMC7834471.

14. Zhou Y, Han T, Chen J, Hou C, Hua L, He S, et al. Clinical and Autoimmune Characteristics of Severe and Critical Cases of COVID-19. Clinical and translational science. 2020;13(6):1077-86. Epub 2020/04/22. doi: 10.1111/cts.12805. PubMed PMID: 32315487; PubMed Central PMCID: PMCPMC7264560.

15. Sacchi MC, Tamiazzo S, Stobbione P, Agatea L, De Gaspari P, Stecca A, et al. SARS-CoV-2 Infection as a trigger of autoimmune response. Clinical and translational science. 2020. Epub 2020/12/12. doi: 10.1111/cts.12953. PubMed PMID: 33306235.

16. Lerma LA, Chaudhary A, Bryan A, Morishima C, Wener MH, Fink SL. Prevalence of autoantibody responses in acute coronavirus disease 2019 (COVID-19). J Transl Autoimmun. 2020;3:100073. Epub 2020/12/03. doi: 10.1016/j.jtauto.2020.100073. PubMed PMID: 33263103; PubMed Central PMCID: PMCPMC7691817.

17. Zhou Y, Zhou B, Pache L, Chang M, Khodabakhshi AH, Tanaseichuk O, et al. Metascape provides a biologist-oriented resource for the analysis of systems-level datasets. Nat Commun. 2019;10(1):1523. doi: 10.1038/s41467-019-09234-6. PubMed PMID: 30944313; PubMed Central PMCID: PMCPMC6447622.

18. Zhang JY, Wang XM, Xing $X, X u Z$, Zhang $C$, Song JW, et al. Single-cell landscape of immunological responses in patients with COVID-19. Nat Immunol. 2020;21(9):1107-18. Epub 2020/08/14. doi: 10.1038/s41590-020-0762-x. PubMed PMID: 32788748.

19. Davies JP, Almasy KM, McDonald EF, Plate L. Comparative Multiplexed Interactomics of SARS-CoV2 and Homologous Coronavirus Nonstructural Proteins Identifies Unique and Shared Host-Cell Dependencies. ACS infectious diseases. 2020;6(12):3174-89. Epub 2020/12/03. doi: 10.1021/acsinfecdis.0c00500. PubMed PMID: 33263384; PubMed Central PMCID: PMCPMC7724760.

20. Klann K, Bojkova D, Tascher G, Ciesek S, Münch C, Cinatl J. Growth Factor Receptor Signaling Inhibition Prevents SARS-CoV-2 Replication. Molecular cell. 2020;80(1):164-74.e4. Epub 2020/09/03. doi: 10.1016/j.molcel.2020.08.006. PubMed PMID: 32877642; PubMed Central PMCID: PMCPMC7418786.

21. Sun J, Ye F, Wu A, Yang R, Pan M, Sheng J, et al. Comparative Transcriptome Analysis Reveals the Intensive Early Stage Responses of Host Cells to SARS-CoV-2 Infection. Frontiers in microbiology. 2020;11:593857. Epub 2020/12/17. doi: 10.3389/fmicb.2020.593857. PubMed PMID: 33324374; PubMed Central PMCID: PMCPMC7723856.

22. Bojkova D, Klann K, Koch B, Widera M, Krause D, Ciesek S, et al. Proteomics of SARS-CoV-2infected host cells reveals therapy targets. Nature. 2020;583(7816):469-72. Epub 2020/05/15. doi: 10.1038/s41586-020-2332-7. PubMed PMID: 32408336.

23. Wilk AJ, Rustagi A, Zhao NQ, Roque J, Martínez-Colón GJ, McKechnie JL, et al. A single-cell atlas of the peripheral immune response in patients with severe COVID-19. Nature medicine. 2020;26(7):1070-6. Epub 2020/06/10. doi: 10.1038/s41591-020-0944-y. PubMed PMID: 32514174; PubMed Central PMCID: PMCPMC7382903.

24. Lieberman NAP, Peddu V, Xie H, Shrestha L, Huang ML, Mears MC, et al. In vivo antiviral host transcriptional response to SARS-CoV-2 by viral load, sex, and age. PLoS biology. 2020;18(9):e3000849. Epub 2020/09/09. doi: 10.1371/journal.pbio.3000849. PubMed PMID: 32898168; PubMed Central PMCID: PMCPMC7478592.

25. Riva L, Yuan S, Yin X, Martin-Sancho L, Matsunaga N, Pache L, et al. Discovery of SARS-CoV-2 antiviral drugs through large-scale compound repurposing. Nature. 2020;586(7827):113-9. Epub 2020/07/25. doi: 10.1038/s41586-020-2577-1. PubMed PMID: 32707573; PubMed Central PMCID: PMCPMC7603405.

26. Bouhaddou M, Memon D, Meyer B, White KM, Rezelj VV, Correa Marrero M, et al. The Global Phosphorylation Landscape of SARS-CoV-2 Infection. Cell. 2020;182(3):685-712.e19. Epub 2020/07/10. doi: 10.1016/j.cell.2020.06.034. PubMed PMID: 32645325; PubMed Central PMCID: PMCPMC7321036. 
27. Blanco-Melo D, Nilsson-Payant BE, Liu WC, Uhl S, Hoagland D, Møller R, et al. Imbalanced Host Response to SARS-CoV-2 Drives Development of COVID-19. Cell. 2020;181(5):1036-45.e9. Epub 2020/05/18. doi: 10.1016/j.cell.2020.04.026. PubMed PMID: 32416070; PubMed Central PMCID: PMCPMC7227586.

28. Shen B, Yi X, Sun Y, Bi X, Du J, Zhang C, et al. Proteomic and Metabolomic Characterization of COVID-19 Patient Sera. Cell. 2020;182(1):59-72.e15. Epub 2020/06/04. doi: 10.1016/j.cell.2020.05.032. PubMed PMID: 32492406; PubMed Central PMCID: PMCPMC7254001.

29. Lamers MM, Beumer J, van der Vaart J, Knoops K, Puschhof J, Breugem TI, et al. SARS-CoV-2 productively infects human gut enterocytes. Science (New York, NY). 2020;369(6499):50-4. Epub 2020/05/03. doi: 10.1126/science.abc1669. PubMed PMID: 32358202; PubMed Central PMCID: PMCPMC7199907.

30. Gordon DE, Jang GM, Bouhaddou M, Xu J, Obernier K, White KM, et al. A SARS-CoV-2 protein interaction map reveals targets for drug repurposing. Nature. 2020;583(7816):459-68. Epub 2020/05/01. doi: 10.1038/s41586-020-2286-9. PubMed PMID: 32353859; PubMed Central PMCID: PMCPMC7431030. 31. Xiong $Y$, Liu Y, Cao L, Wang D, Guo M, Jiang A, et al. Transcriptomic characteristics of bronchoalveolar lavage fluid and peripheral blood mononuclear cells in COVID-19 patients. Emerging microbes \& infections. 2020;9(1):761-70. Epub 2020/04/02. doi: 10.1080/22221751.2020.1747363. PubMed PMID: 32228226; PubMed Central PMCID: PMCPMC7170362.

32. Vanderheiden A, Ralfs P, Chirkova T, Upadhyay AA, Zimmerman MG, Bedoya S, et al. Type I and Type III Interferons Restrict SARS-CoV-2 Infection of Human Airway Epithelial Cultures. Journal of virology. 2020;94(19). Epub 2020/07/24. doi: 10.1128/jvi.00985-20. PubMed PMID: 32699094; PubMed Central PMCID: PMCPMC7495371.

33. Appelberg S, Gupta S, Svensson Akusjärvi S, Ambikan AT, Mikaeloff F, Saccon E, et al. Dysregulation in Akt/mTOR/HIF-1 signaling identified by proteo-transcriptomics of SARS-CoV-2 infected cells. Emerging microbes \& infections. 2020;9(1):1748-60. Epub 2020/07/22. doi: 10.1080/22221751.2020.1799723. PubMed PMID: 32691695; PubMed Central PMCID: PMCPMC7473213.

34. Stukalov A, Girault V, Grass V, Bergant V, Karayel O, Urban C, et al. Multi-level proteomics reveals host-perturbation strategies of SARS-CoV-2 and SARS-CoV. bioRxiv : the preprint server for biology. 2020:2020.06.17.156455. doi: 10.1101/2020.06.17.156455.

35. Emanuel W, Kirstin M, Vedran F, Asija D, Theresa GL, Roberto A, et al. Bulk and single-cell gene expression profiling of SARS-CoV-2 infected human cell lines identifies molecular targets for therapeutic intervention. bioRxiv. 2020:2020.05.05.079194. doi: 10.1101/2020.05.05.079194.

36. Li Y, Wang Y, Liu H, Sun W, Ding B, Zhao Y, et al. Urine Proteome of COVID-19 Patients. medRxiv. 2020:2020.05.02.20088666. doi: 10.1101/2020.05.02.20088666.

37. Liao M, Liu Y, Yuan J, Wen Y, Xu G, Zhao J, et al. Single-cell landscape of bronchoalveolar immune cells in patients with COVID-19. Nature medicine. 2020;26(6):842-4. Epub 2020/05/14. doi: 10.1038/s41591-020-0901-9. PubMed PMID: 32398875.

38. Laurent EMN, Sofianatos Y, Komarova A, Gimeno J-P, Tehrani PS, Kim D-K, et al. Global BiolDbased SARS-CoV-2 proteins proximal interactome unveils novel ties between viral polypeptides and host factors involved in multiple COVID19-associated mechanisms. bioRxiv. 2020:2020.08.28.272955. doi: 10.1101/2020.08.28.272955.

39. Alfraji N, Mazahir U, Chaudhri M, Miskoff J. Anti-synthetase syndrome: a rare and challenging diagnosis for bilateral ground-glass opacities-a case report with literature review. BMC pulmonary medicine. 2021;21(1):11. Epub 2021/01/08. doi: 10.1186/s12890-020-01388-0. PubMed PMID: 33407281; PubMed Central PMCID: PMCPMC7787399.

40. Thoms M, Buschauer R, Ameismeier M, Koepke L, Denk T, Hirschenberger M, et al. Structural basis for translational shutdown and immune evasion by the Nsp1 protein of SARS-CoV-2. Science (New York, 
NY). 2020;369(6508):1249-55. Epub 2020/07/19. doi: 10.1126/science.abc8665. PubMed PMID: 32680882; PubMed Central PMCID: PMCPMC7402621.

41. Li Q, Zhang YY, Chiu S, Hu Z, Lan KH, Cha H, et al. Integrative functional genomics of hepatitis C virus infection identifies host dependencies in complete viral replication cycle. PLoS pathogens. 2014;10(5):e1004163. Epub 2014/05/24. doi: 10.1371/journal.ppat.1004163. PubMed PMID: 24852294; PubMed Central PMCID: PMCPMC4095987.

42. Hahn F, Schmalen A, Setz C, Friedrich M, Schlößer S, Kölle J, et al. Proteolysis of mature HIV-1 p6 Gag protein by the insulin-degrading enzyme (IDE) regulates virus replication in an Env-dependent manner. PloS one. 2017;12(4):e0174254. Epub 2017/04/08. doi: 10.1371/journal.pone.0174254. PubMed PMID: 28388673; PubMed Central PMCID: PMCPMC5384750.

43. Carpenter JE, Jackson W, de Souza GA, Haarr L, Grose C. Insulin-degrading enzyme binds to the nonglycosylated precursor of varicella-zoster virus gE protein found in the endoplasmic reticulum. Journal of virology. 2010;84(2):847-55. Epub 2009/10/30. doi: 10.1128/jvi.01801-09. PubMed PMID: 19864391; PubMed Central PMCID: PMCPMC2798375.

44. Flach $\mathrm{H}$, Rosenbaum M, Duchniewicz M, Kim S, Zhang SL, Cahalan MD, et al. Mzb1 protein regulates calcium homeostasis, antibody secretion, and integrin activation in innate-like B cells. Immunity. 2010;33(5):723-35. Epub 2010/11/26. doi: 10.1016/j.immuni.2010.11.013. PubMed PMID: 21093319; PubMed Central PMCID: PMCPMC3125521.

45. Miyagawa-Hayashino A, Yoshifuji H, Kitagori K, Ito S, Oku T, Hirayama Y, et al. Increase of MZB1 in $B$ cells in systemic lupus erythematosus: proteomic analysis of biopsied lymph nodes. Arthritis research \& therapy. 2018;20(1):13. Epub 2018/02/01. doi: 10.1186/s13075-018-1511-5. PubMed PMID: 29382365; PubMed Central PMCID: PMCPMC5791339.

46. Herold T, Mulaw MA, Jurinovic V, Seiler T, Metzeler KH, Dufour A, et al. High expression of MZB1 predicts adverse prognosis in chronic lymphocytic leukemia, follicular lymphoma and diffuse large B-cell lymphoma and is associated with a unique gene expression signature. Leukemia \& lymphoma. 2013;54(8):1652-7. Epub 2012/11/30. doi: 10.3109/10428194.2012.753445. PubMed PMID: 23189934.

47. Schiller HB, Mayr CH, Leuschner G, Strunz M, Staab-Weijnitz C, Preisendörfer S, et al. Deep Proteome Profiling Reveals Common Prevalence of MZB1-Positive Plasma B Cells in Human Lung and Skin Fibrosis. American journal of respiratory and critical care medicine. 2017;196(10):1298-310. Epub 2017/06/28. doi: 10.1164/rccm.201611-22630C. PubMed PMID: 28654764; PubMed Central PMCID: PMCPMC6913086.

48. Rosenbaum M, Andreani V, Kapoor T, Herp S, Flach H, Duchniewicz M, et al. MZB1 is a GRP94 cochaperone that enables proper immunoglobulin heavy chain biosynthesis upon ER stress. Genes \& development. 2014;28(11):1165-78. Epub 2014/06/04. doi: 10.1101/gad.240762.114. PubMed PMID: 24888588; PubMed Central PMCID: PMCPMC4052763.

49. Szklarczyk D, Gable AL, Lyon D, Junge A, Wyder S, Huerta-Cepas J, et al. STRING v11: proteinprotein association networks with increased coverage, supporting functional discovery in genome-wide experimental datasets. Nucleic Acids Res. 2019;47(D1):D607-D13. doi: 10.1093/nar/gky1131. PubMed PMID: 30476243; PubMed Central PMCID: PMCPMC6323986. 


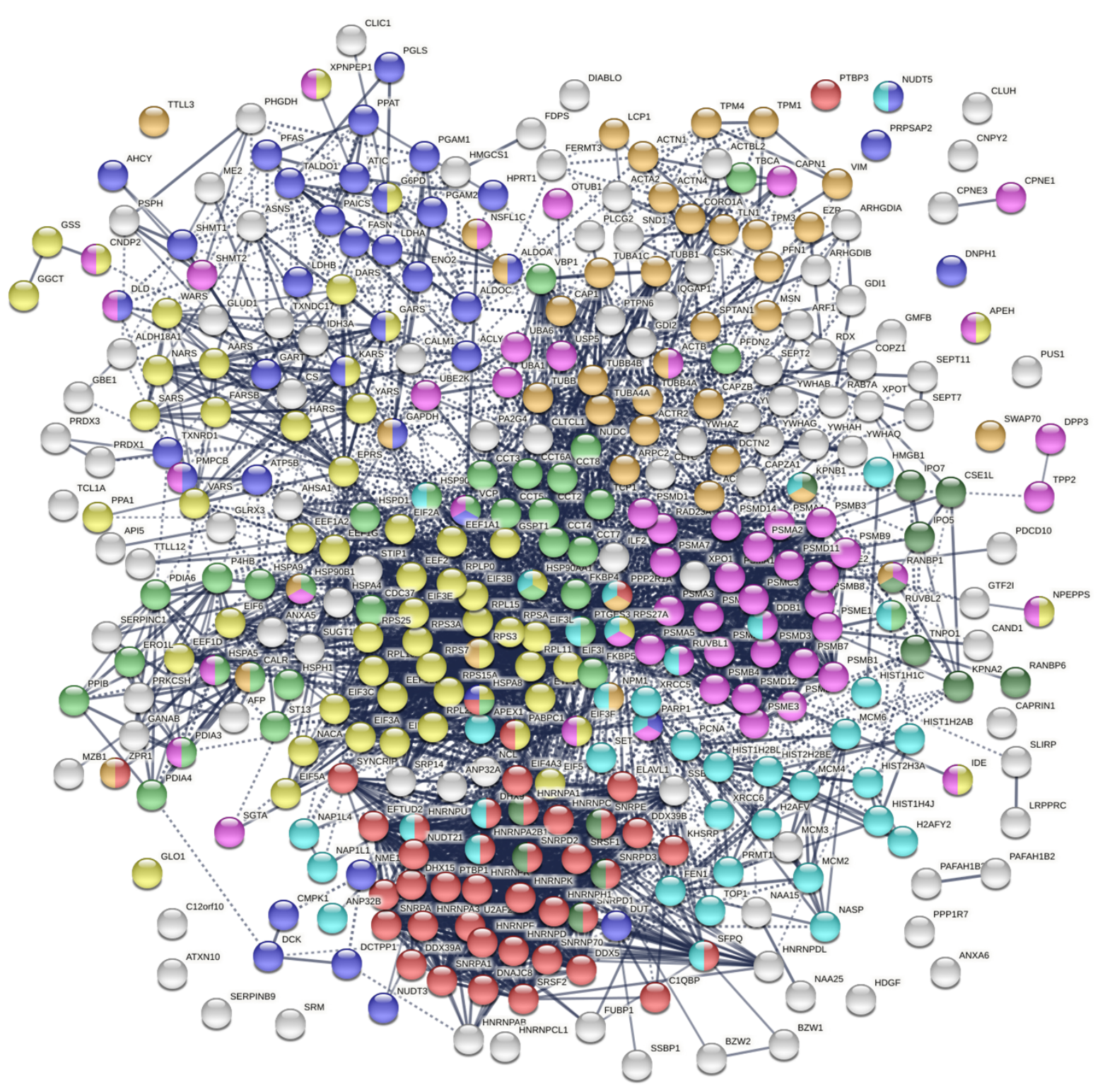

Fig. 1. The autoantigen-ome of HS-Sultan cells identified by DS-affinity. Marked proteins are associated with peptide biosynthesis and catabolic process (58 proteins, yellow), protein folding (34 proteins, light green), RNA splicing (41 proteins, red), nucleobase-containing small molecule metabolic process (39 proteins, blue), proteolysis (55 proteins, pink), import into nuclear (13 proteins, dark green), cytoskeleton organization (39 proteins, amber), and chromosome organization (40 proteins, aqua). 
bioRxiv preprint doi: https://doi.org/10.1101/2021.04.05.438500; this version posted April 6, 2021. The copyright holder for this preprint (which was not certified by peer review) is the author/funder, who has granted bioRxiv a license to display the preprint in perpetuity. It is made available under aCC-BY 4.0 International license.

\section{A. HS-Sultan autoantigen-ome}

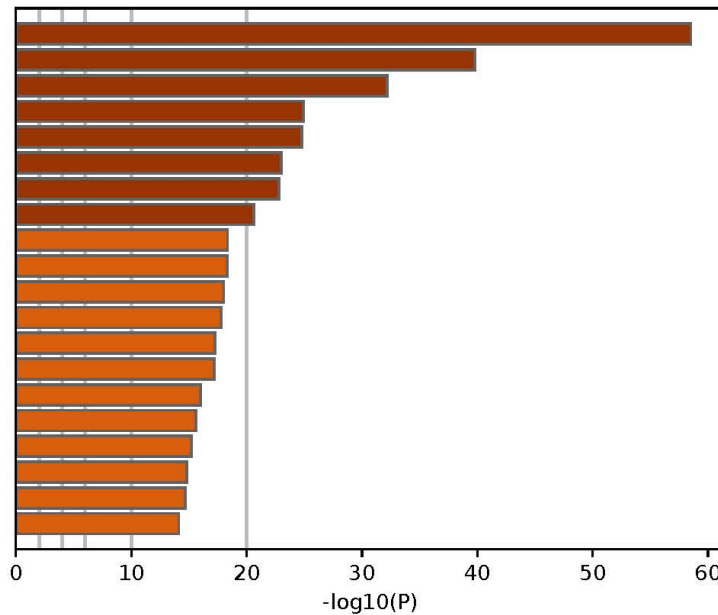

GO:0034655: nucleobase-containing compound catabolic process GO:0043043: peptide biosynthetic process GO:0006457: protein folding

R-HSA-72163: mRNA Splicing - Major Pathway

R-HSA-6798695: Neutrophil degranulation

R-HSA-389957: Prefoldin mediated transfer of substrate to CCT/TriC WP107: Translation Factors

GO:0006913: nucleocytoplasmic transport

R-HSA-379716: Cytosolic tRNA aminoacylation

GO:0034248: regulation of cellular amide metabolic process

WP2359: Parkin-Ubiquitin Proteasomal System pathway

GO:0071826: ribonucleoprotein complex subunit organization

CORUM:5199: Kinase maturation complex 1

WP3888: VEGFA-VEGFR2 Signaling Pathway

WP4290: Metabolic reprogramming in colon cancer

R-HSA-3371497: HSP90 chaperone cycle for steroid hormone receptors (SHR)

GO:0035722: interleukin-12-mediated signaling pathway

CORUM:5615: Emerin complex 52

GO:0071103: DNA conformation change

hsa01200: Carbon metabolism

\section{B. COVID-altered}

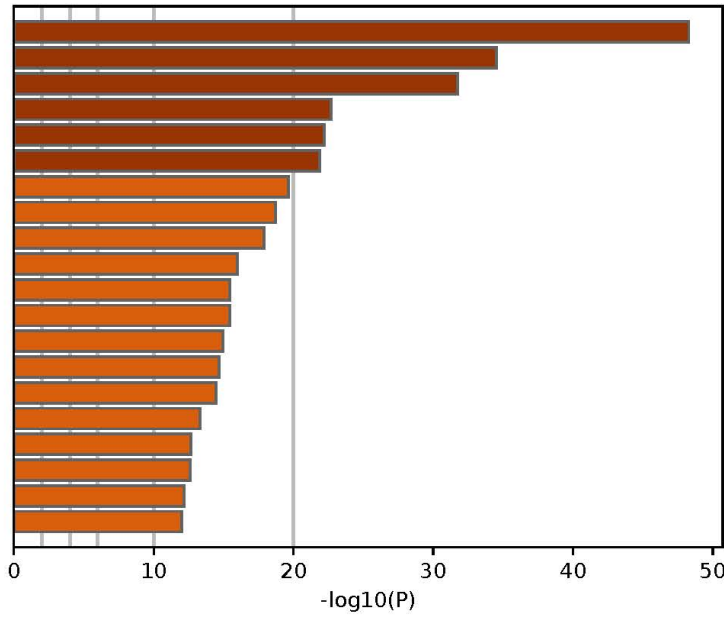

R-HSA-8953854: Metabolism of RNA

GO:0006457: protein folding

GO:0043043: peptide biosynthetic process

GO:0072594: establishment of protein localization to organelle

WP411: mRNA Processing

R-HSA-389957: Prefoldin mediated transfer of substrate to CCT/TriC

GO:0036230: granulocyte activation

GO:0006403: RNA localization

CORUM:5199: Kinase maturation complex 1

GO:0034248: regulation of cellular amide metabolic process

CORUM:5615: Emerin complex 52

WP3888: VEGFA-VEGFR2 Signaling Pathway

R-HSA-3371497: HSP90 chaperone cycle for steroid hormone receptors (SHR)

WP2359: Parkin-Ubiquitin Proteasomal System pathway

GO:0035722: interleukin-12-mediated signaling pathway

GO:0071103: DNA conformation change

GO:0061077: chaperone-mediated protein folding

M66: PID MYC ACTIV PATHWAY

CORUM: 1183: CDC5L complex

WP4290: Metabolic reprogramming in colon cancer

Fig. 2. Top 20 enriched pathways and processes among COVID-altered autoAgs. Top: Pathways of 362 proteins identified by DS-affinity from HS-Sultan cells. Bottom: Pathways of 316 DS-affinity proteins that are altered in COVID. 
bioRxiv preprint doi: https://doi.org/10.1101/2021.04.05.438500; this version posted April 6, 2021. The copyright holder for this preprint (which

was not certified by peer review) is the author/funder, who has granted bioRxiv a license to display the preprint in perpetuity. It is made available under aCC-BY 4.0 International license.

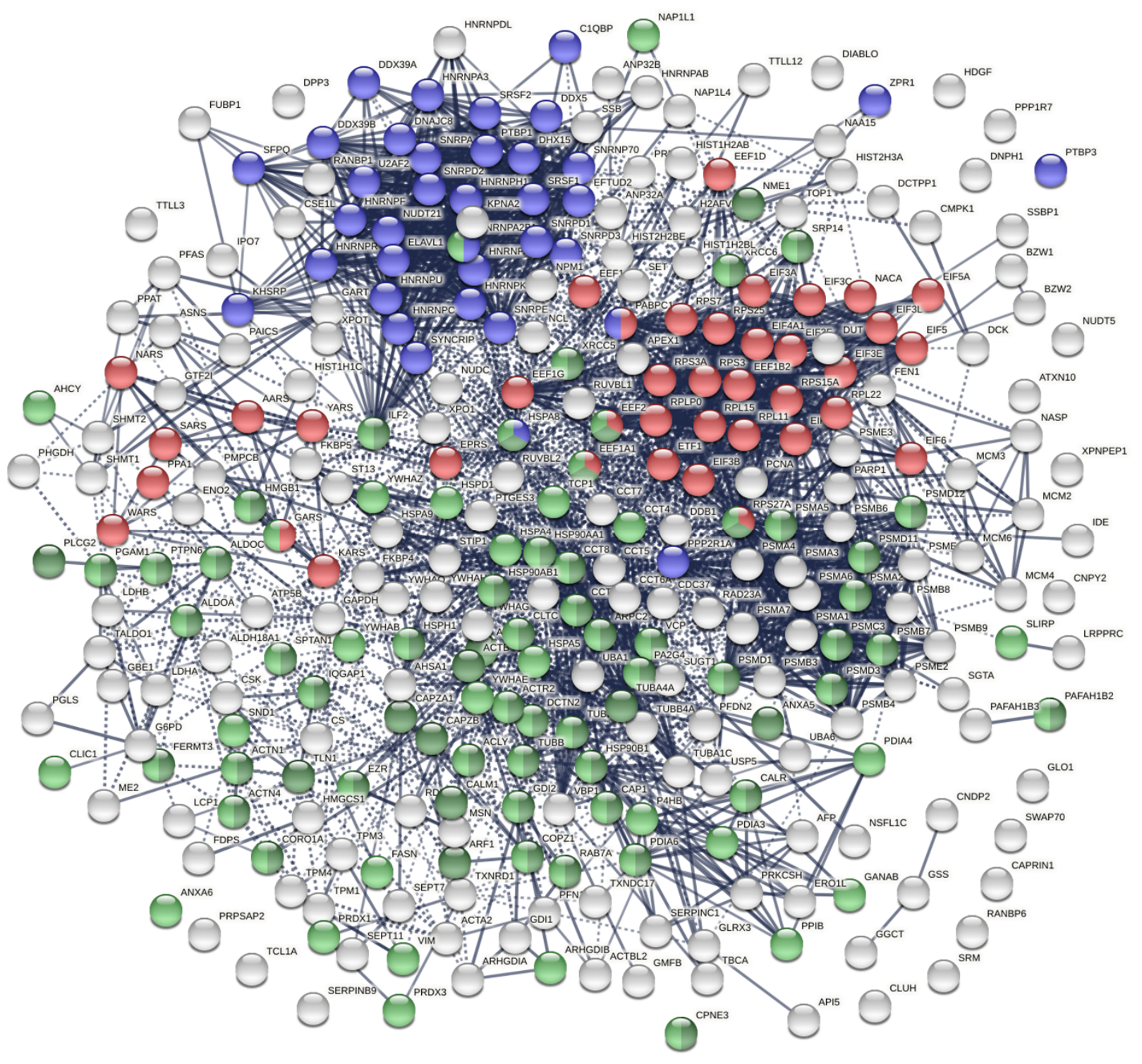

Fig. 3. COVID-affected proteins shared with the HS-Sultan autoantigen-ome. Marked proteins are associated with RNA splicing (36 proteins, blue), translation (39 proteins, red), vesicle (77 proteins, green) and vesicle-mediated transport (62 proteins, dark green). 
bioRxiv preprint doi: https://doi.org/10.1101/2021.04.05.438500; this version posted April 6, 2021. The copyright holder for this preprint (which was not certified by peer review) is the author/funder, who has granted bioRxiv a license to display the preprint in perpetuity. It is made available under aCC-BY 4.0 International license.
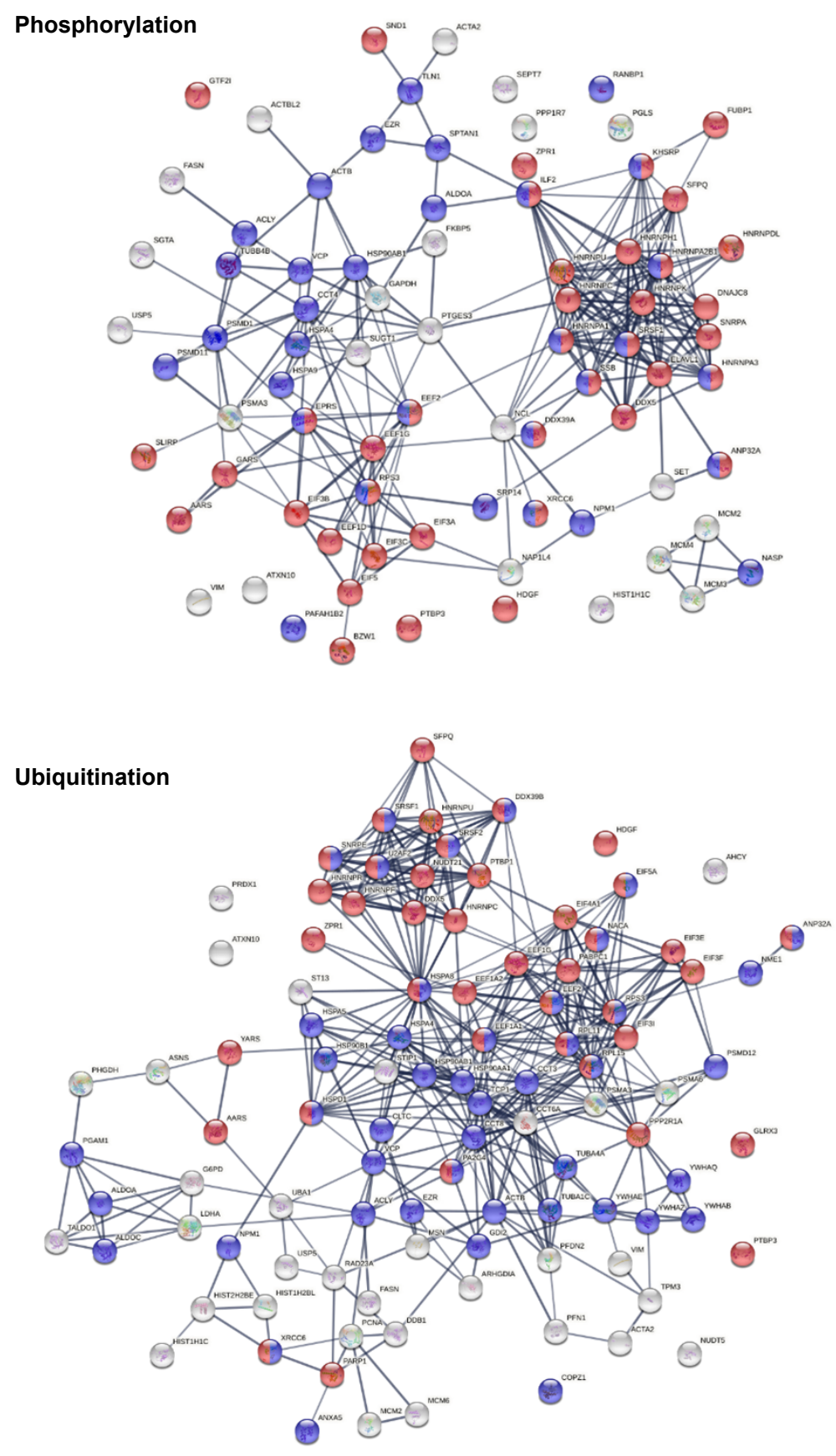

Fig. 4. DS-affinity proteins that are altered by phosphorylation or ubiquitination in SARSCoV-2 infection. Marked proteins are associated with gene expression (red) and transport (blue). 

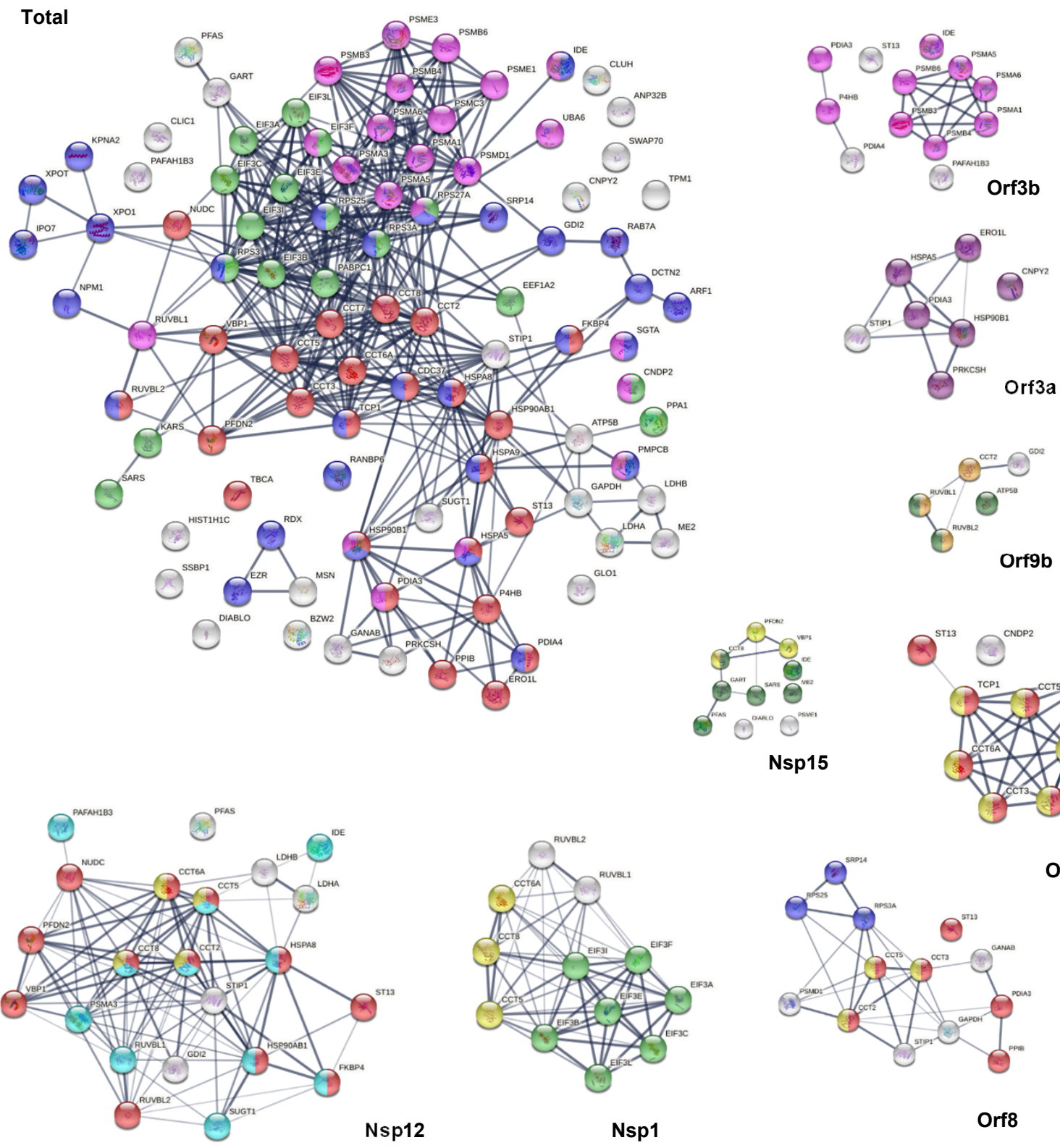

Fig. 5. DS-affinity proteins in the SARS-CoV-2 interactomes. Total: marked proteins are involved in protein folding (25 proteins, red), peptide biosynthetic process (17 proteins, green), protein localization (29 proteins, blue), or proteolysis (22 proteins, pink). Orf3b: proteolysis (pink). Orf3a: endoplasmic reticulum (dark purple). Orf9b: nuclear function of prefoldin (amber), AAA+ ATPase domain or P-loop containing nucleoside triphosphate hydrolase (dark green). Nsp15: prefoldin-mediated transfer of substrate to CCT/TriC (yellow), nucleotide binding (dark green). Orf10: protein folding (red), CCT chaperonin (yellow). Orf8: protein folding (red), SRP-dependent cotranslational protein targeting to membrane (blue), CCT chaperonin (yellow). Nsp1: translation initiation (green), CCT chaperonin (yellow). Nsp12: protein folding (red), multi-organism process (aqua), CCT chaperonin (yellow). 

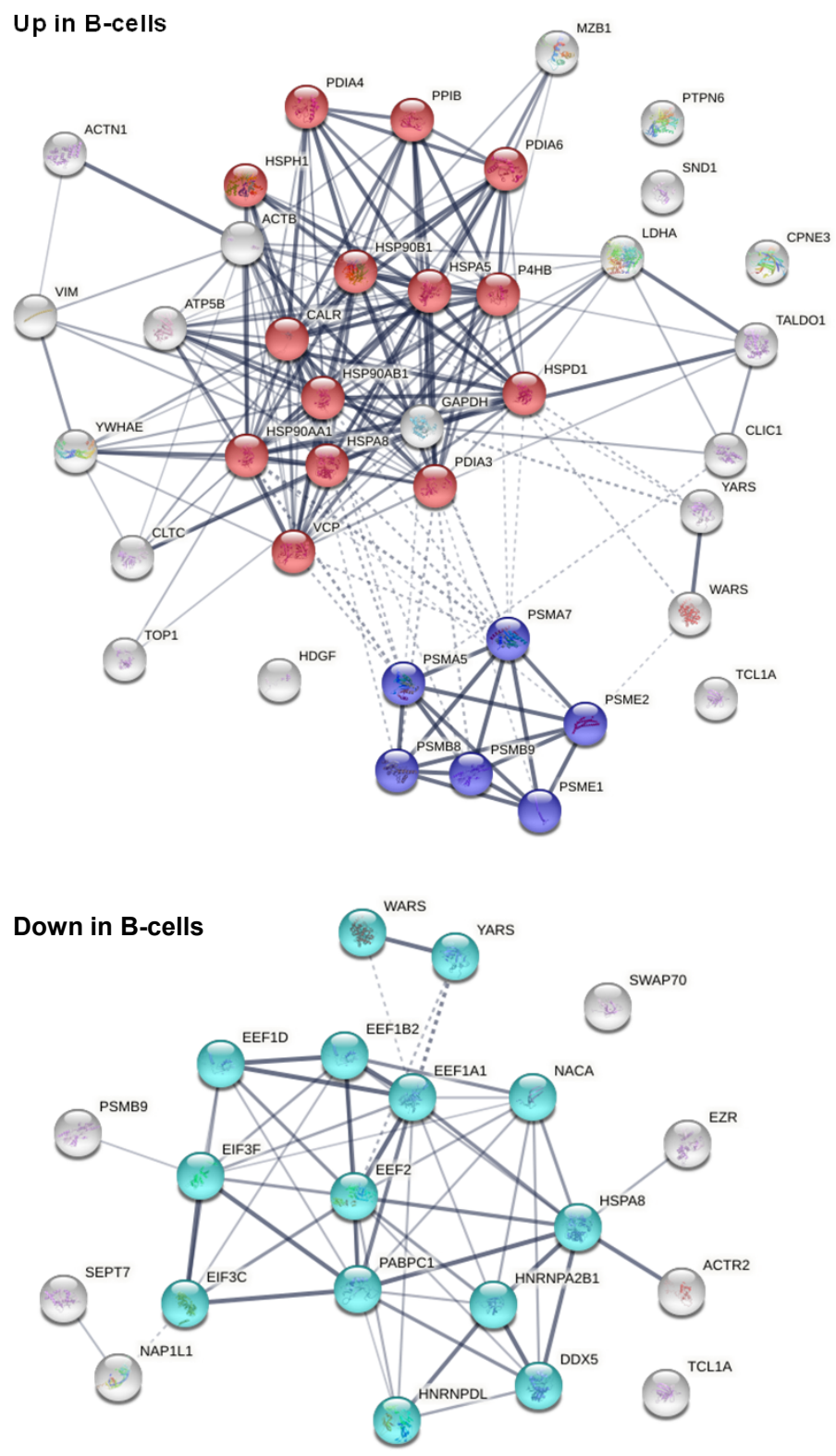

Fig. 6. DS-affinity proteins from HS-Sultan cells that are up-regulated or down-regulated in B-cells of COVID-19 patients. Top: 39 up-regulated proteins. Red: protein processing in ER. Blue: proteasome. Bottom: 21 down-regulated proteins. Aqua: proteins involved in gene expression. 
bioRxiv preprint doi: https://doi.org/10.1101/2021.04.05.438500; this version posted April 6, 2021. The copyright holder for this preprint (which was not certified by peer review) is the author/funder, who has granted bioRxiv a license to display the preprint in perpetuity. It is made available under aCC-BY 4.0 International license.

Table 1. DS-affinity autoantigens from HS-Sultan cells and their alteration in COVID-19

\begin{tabular}{|c|c|c|c|c|c|c|c|c|}
\hline \multirow{2}{*}{$\begin{array}{c}\text { Number of } \\
\text { Peptides }\end{array}$} & \multirow[b]{2}{*}{ AARS } & \multirow{2}{*}{ Alanine-tRNA ligase, cytoplasmic } & \multicolumn{2}{|c|}{$\begin{array}{l}\text { Alteration in COVID } \\
\text { (up and/or down) }\end{array}$} & \multirow[t]{2}{*}{$\begin{array}{l}\text { SARS-CoV-2 } \\
\text { interaction }\end{array}$} & \multirow[t]{2}{*}{$\begin{array}{l}\text { DS- } \\
\text { affinity } \\
\text { (1.0 M) }\end{array}$} & \multirow{2}{*}{$\begin{array}{c}\begin{array}{c}\text { DS- } \\
\text { affinity } \\
(0.5 \mathrm{M}) \\
+\end{array} \\
\end{array}$} & \multirow{2}{*}{$\begin{array}{l}\text { Ref. } \\
{[1]}\end{array}$} \\
\hline & & & u & $d$ & & & & \\
\hline 15 & ACLY & ATP-citrate synthase & $\mathrm{u}$ & $d$ & & & + & {$[2]$} \\
\hline 9 & ACTA2 & Actin, aortic smooth muscle & u & $d$ & & & + & [3] \\
\hline 6 & ACTB & Actin, cytoplasmic 1 & u & $d$ & & & + & [4] \\
\hline 7 & ACTBL2 & Beta-actin-like protein 2 & u & $d$ & & & + & [4] \\
\hline 8 & ACTN1 & Alpha-actinin-1 (f-actin cross linking protein) & $\mathrm{u}$ & $d$ & & & + & [5] \\
\hline 7 & ACTN4 & Alpha-actinin-4 & u & $d$ & & & + & [5] \\
\hline 2 & ACTR2 & Actin-related protein 2 & u & $d$ & & & + & [6] \\
\hline 2 & ACTR3 & Actin-related protein 3 & $\mathrm{u}$ & & & & + & [7] \\
\hline 3 & AFP & Alpha-fetoprotein & & $d$ & & & + & [8] \\
\hline 15 & $\mathrm{AHCY}$ & Adenosylhomocysteinase & & $d$ & & & + & \\
\hline 4 & AHSA1 & Activator of $90 \mathrm{kDa}$ heat shock protein ATPase homolog 1 & & $d$ & & & + & \\
\hline 5 & ALDH18A1 & Delta-1-pyrroline-5-carboxylate synthetase & & $d$ & & & + & \\
\hline 3 & ALDOA & Fructose-bisphosphate aldolase A & u & $d$ & & & + & [9] \\
\hline 4 & ALDOC & Fructose-bisphosphate aldolase C & u & $d$ & & & + & {$[10]$} \\
\hline 2 & ANP32A & $\begin{array}{l}\text { Acidic leucine-rich nuclear phosphoprotein } 32 \text { family } \\
\text { member A }\end{array}$ & $\mathrm{u}$ & $d$ & & & + & \\
\hline 4 & ANP32B & $\begin{array}{l}\text { Acidic leucine-rich nuclear phosphoprotein } 32 \text { family } \\
\text { member B }\end{array}$ & & $d$ & $\mathrm{~N}$ & & + & {$[11]$} \\
\hline 2 & ANP32C & $\begin{array}{l}\text { Acidic leucine-rich nuclear phosphoprotein } 32 \text { family } \\
\text { member C }\end{array}$ & & & & & + & \\
\hline 8 & ANXA5 & Annexin A5 & $\mathrm{u}$ & $d$ & & & + & {$[12]$} \\
\hline 5 & ANXA6 & Annexin A6 & u & $d$ & & & + & [13] \\
\hline 4 & APEH & Acylamino-acid-releasing enzyme & & & & & + & \\
\hline 2 & APEX1 & DNA-(apurinic or apyrimidinic site) lyase & $\mathrm{u}$ & $d$ & & & + & [14] \\
\hline 2 & API5 & Apoptosis inhibitor 5 & & $d$ & & & + & \\
\hline 8 & ARF1 & ADP-ribosylation factor 1 & & & Nsp6 & & + & \\
\hline 6 & ARHGDIA & Rho GDP-dissociation inhibitor 1 & u & $d$ & & & + & \\
\hline 8 & ARHGDIB & Rho GDP-dissociation inhibitor 2 & & $d$ & & & + & {$[15]$} \\
\hline 3 & ARPC2 & Actin-related protein $2 / 3$ complex subunit 2 & & $d$ & & & + & \\
\hline 2 & ASNS & Asparagine synthetase [glutamine-hydrolyzing] & u & & & & + & \\
\hline 14 & ATIC & Bifunctional purine biosynthesis protein, PURH & & & & & + & [16] \\
\hline 13 & ATP5F1B & ATP synthase subunit beta, mitochondrial, ATP5B & $\mathrm{u}$ & $d$ & Nsp6 & + & & {$[17]$} \\
\hline 3 & ATXN10 & Ataxin-10, Spinocerebellar ataxia type 10 protein & u & $d$ & & & + & \\
\hline 2 & BZW1 & Basic leucine zipper and W2 domain-containing protein 1 & u & & & & + & \\
\hline 3 & BZW2 & Basic leucine zipper and W2 domain-containing protein 2 & & & $\mathrm{~N}$ & & + & \\
\hline 2 & C1QBP & $\begin{array}{l}\text { Complement component } 1 \mathrm{Q} \text { subcomponent-binding } \\
\text { protein }\end{array}$ & & $d$ & & & + & {$[18]$} \\
\hline 8 & CALM1 & Calmodulin & $\mathrm{u}$ & $d$ & & & + & [19] \\
\hline 13 & CALR & Calreticulin & $\mathrm{u}$ & $d$ & & & + & {$[20]$} \\
\hline 15 & CAND1 & Cullin-associated NEDD8-dissociated protein 1 & & & & & + & \\
\hline 6 & CAP1 & Adenylyl cyclase-associated protein 1 & $\mathrm{u}$ & $d$ & & & + & \\
\hline 3 & CAPN1 & Calpain-1 catalytic subunit & & & & & + & \\
\hline 2 & CAPRIN1 & Caprin-1, Cell cycle associated protein 1 & & $d$ & & & + & \\
\hline 3 & CAPZA1 & F-actin capping protein subunit alpha-1 (capz alpha-1) & & $d$ & & & + & {$[21]$} \\
\hline 3 & CAPZB & F-actin-capping protein subunit beta & & $d$ & & & + & {$[22]$} \\
\hline 10 & ССТ2 & T-complex protein 1 subunit beta (tcp-1-beta) (cct-beta) & & $d$ & $\begin{array}{c}\text { Nsp12 } \\
\text { Orf8 } \\
\text { Orf9b } \\
\text { Orf10 }\end{array}$ & & + & {$[23]$} \\
\hline 6 & ССТ3 & $\begin{array}{l}\text { T-complex protein } 1 \text { subunit gamma (chaperonin containing } \\
\text { TCP1, subunit } 3 \text { isoform) }\end{array}$ & $\mathrm{u}$ & & $\begin{array}{l}\text { Orf8 } \\
\text { Orf10 }\end{array}$ & & + & {$[24]$} \\
\hline 6 & ССТ4 & $\begin{array}{l}\text { T-complex protein } 1 \text { subunit delta (tcp-1-delta) (cct-delta) } \\
\text { (stimulator of tar rna-binding) }\end{array}$ & $\mathrm{u}$ & & & & + & {$[24]$} \\
\hline 10 & CCT5 & $\begin{array}{l}\text { T-complex protein } 1 \text { subunit epsilon (tcp-1-epsilon) (cct- } \\
\text { epsilon) }\end{array}$ & $\mathrm{u}$ & $d$ & $\begin{array}{c}\text { Nsp1 } \\
\text { Nsp12 } \\
\text { Orf8 } \\
\text { Orf10 }\end{array}$ & & + & {$[23]$} \\
\hline 7 & ССТ6А & $\begin{array}{l}\text { T-complex protein } 1 \text { subunit zeta (acute morphine } \\
\text { dependence-related protein } 2 \text { ) }\end{array}$ & $\mathrm{u}$ & $d$ & $\begin{array}{l}\text { Nsp1 } \\
\text { Nsp12 } \\
\text { Orf10 }\end{array}$ & & + & {$[23]$} \\
\hline
\end{tabular}


bioRxiv preprint doi: https://doi.org/10.1101/2021.04.05.438500; this version posted April 6, 2021. The copyright holder for this preprint (which was not certified by peer review) is the author/funder, who has granted bioRxiv a license to display the preprint in perpetuity. It is made available under aCC-BY 4.0 International license.

\begin{tabular}{|c|c|c|c|c|c|c|c|}
\hline 5 & CCT7 & $\begin{array}{l}\text { T-complex protein } 1 \text { subunit eta (hiv-1 nef-interacting } \\
\text { protein) }\end{array}$ & & & Orf10 & + & {$[23]$} \\
\hline 20 & СCT8 & T-complex protein 1 subunit theta & $\mathrm{u}$ & $d$ & $\begin{array}{c}\text { Nsp1 } \\
\text { Nsp12 } \\
\text { Nsp14 }\end{array}$ & + & {$[24]$} \\
\hline 4 & CDC37 & $\begin{array}{l}\text { Hsp90 co-chaperone, hsp90 chaperone protein kinase- } \\
\text { targeting }\end{array}$ & $\mathrm{u}$ & $d$ & Nsp16 & + & \\
\hline 6 & CLIC1 & Chloride intracellular channel protein 1 & u & $d$ & Nsp16 & + & [25] \\
\hline 12 & CLTC & Clathrin heavy chain 1 & $\mathrm{u}$ & $d$ & & + & [26] \\
\hline 4 & CLTCL1 & Clathrin heavy chain 2 & & & & + & \\
\hline 4 & $\mathrm{CLUH}$ & Clustered mitochondria protein homolog (mRNA-binding) & & $d$ & $\begin{array}{c}\text { Nsp7 } \\
\text { Nsp16 }\end{array}$ & + & \\
\hline 2 & CMPK1 & UMP-CMP kinase & & $d$ & & + & \\
\hline 3 & CNDP2 & Cytosolic non-specific dipeptidase & $\mathrm{u}$ & & $\begin{array}{l}\text { Orf3 } \\
\text { Orf10 }\end{array}$ & + & \\
\hline 2 & CNPY2 & Protein canopy homolog 2, MSAP, TMEM4, Zsig9 & & $d$ & Orf3a & + & \\
\hline 2 & COPZ1 & Coatomer subunit zeta-1 & & $d$ & & + & \\
\hline 12 & CORO1A & Coronin-1A & $\mathrm{u}$ & & & + & {$[27]$} \\
\hline 3 & CPNE1 & Copine-1 & & & & + & \\
\hline 4 & CPNE3 & Copine-3 & $\mathrm{u}$ & $d$ & & + & \\
\hline 3 & CS & Citrate synthase, mitochondrial & u & $d$ & & + & [2] \\
\hline 10 & CSE1L & Exportin-2 & & $d$ & & + & \\
\hline 4 & CSK & Tyrosine-protein kinase CSK & & $\mathrm{d}$ & & + & [28] \\
\hline 6 & DARS & Aspartate-tRNA ligase, cytoplasmic, DARS1 & & & & + & [29] \\
\hline 3 & DCK & Deoxycytidine kinase & $\mathrm{u}$ & & & + & \\
\hline 3 & DCTN2 & Dynactin subunit 2 & & & Orf6 & + & \\
\hline 3 & DCTPP1 & dCTP pyrophosphatase 1 & & $d$ & & + & \\
\hline 7 & DDB1 & DNA damage-binding protein 1 & $\mathrm{u}$ & $d$ & & + & {$[26]$} \\
\hline 4 & DDX39A & ATP-dependent RNA helicase DDX39A & $\mathrm{u}$ & $d$ & & + & \\
\hline 3 & DDX39B & Spliceosome RNA helicase DDX39B & & $d$ & & + & \\
\hline 2 & DDX5 & Probable ATP-dependent RNA helicase, RNA helicase p68 & u & $\mathrm{d}$ & & + & {$[30]$} \\
\hline 2 & DHX15 & $\begin{array}{l}\text { Pre-mRNA-splicing factor ATP-dependent RNA helicase } \\
\text { DHX15 }\end{array}$ & & $d$ & & + & \\
\hline 3 & DHX9 & ATP-dependent RNA helicase A & & & & + & [31] \\
\hline 3 & DIABLO & Diablo homolog, mitochondrial & $\mathrm{u}$ & $d$ & $\begin{array}{c}\text { Nsp6 } \\
\text { Nsp15 }\end{array}$ & + & \\
\hline 4 & DLD & Dihydrolipoyl dehydrogenase, mitochondrial & & & & + & [32] \\
\hline 2 & DNAJC8 & DnaJ homolog subfamily $\mathrm{C}$ member 8 & $\mathrm{u}$ & & & + & \\
\hline 4 & DNPH1 & 2'-deoxynucleoside 5'-phosphate N-hydrolase 1 & $\mathrm{u}$ & & & + & \\
\hline 6 & DPP3 & Dipeptidyl-peptidase 3 & & $d$ & & + & \\
\hline 5 & DUT & $\begin{array}{l}\text { Deoxyuridine 5'-triphosphate nucleotidohydrolase, } \\
\text { mitochondrial }\end{array}$ & $\mathrm{u}$ & $d$ & & + & \\
\hline 2 & EEF1A1 & Elongation factor 1-alpha & $\mathrm{u}$ & $d$ & & + & [33] \\
\hline 4 & EEF1A2 & Elongation factor 1 -alpha 2 & $\mathrm{u}$ & & Orf3 & + & [34] \\
\hline 2 & EEF1B2 & Elongation factor 1-beta & & $d$ & & + & \\
\hline 5 & EEF1D & Elongation factor 1-delta & & $d$ & & + & [35] \\
\hline 6 & EEF1G & Elongation factor 1-gamma & $\mathrm{u}$ & $d$ & & + & \\
\hline 17 & EEF2 & Elongation factor 2 & $\mathrm{u}$ & $d$ & & + & [36] \\
\hline 2 & EFTUD2 & U5 small nuclear ribonucleoprotein component $116 \mathrm{kda}$ & & $d$ & & + & [37] \\
\hline 3 & EIF2A & $\begin{array}{l}\text { Eukaryotic translation initiation factor } 2 \text { subunit alpha, } \\
\text { EIF2S1 }\end{array}$ & & & & + & \\
\hline 5 & EIF3A & Eukaryotic translation initiation factor 3 subunit A & u & $d$ & Nsp1 & + & [38] \\
\hline 5 & EIF3B & Eukaryotic translation initiation factor 3 subunit $B$ & u & $d$ & Nsp1 & + & \\
\hline 2 & EIF3C & Eukaryotic translation initiation factor 3 subunit $\mathrm{C}$ & & $\mathrm{d}$ & Nsp1 & & [39] \\
\hline 3 & EIF3E & $\begin{array}{l}\text { Eukaryotic translation initiation factor } 3 \text { subunit E (viral } \\
\text { integration site protein int- } 6 \text { homolog) }\end{array}$ & u & $d$ & Nsp1 & + & [40] \\
\hline 4 & EIF3F & Eukaryotic translation initiation factor 3 subunit $F$ & $\mathrm{u}$ & $d$ & Nsp1 & + & \\
\hline 2 & EIF3I & Eukaryotic translation initiation factor 3 subunit I & & $d$ & Nsp1 & + & [39] \\
\hline 10 & EIF3L & $\begin{array}{l}\text { Eukaryotic translation initiation factor } 3 \text { subunit L (subunit } \mathrm{E} \\
\text { interacting protein) }\end{array}$ & & $d$ & Nsp1 & + & \\
\hline 19 & EIF4A1 & Eukaryotic initiation factor $4 \mathrm{~A}-\mathrm{I}$ & $\mathrm{u}$ & $d$ & & + & \\
\hline 4 & EIF4A3 & Eukaryotic initiation factor $4 \mathrm{~A}-\mathrm{III}$ & & & & + & [41] \\
\hline 2 & EIF5 & Eukaryotic translation initiation factor 5 & $\mathrm{u}$ & $d$ & & + & [42] \\
\hline 5 & EIF5A & Eukaryotic translation initiation factor $5 \mathrm{~A}-1$ & $\mathrm{u}$ & $d$ & & + & [42] \\
\hline 2 & EIF6 & Eukaryotic translation initiation factor 6 & u & & & + & \\
\hline 3 & ELAVL1 & ELAV-like protein 1 & & $d$ & & + & [43] \\
\hline
\end{tabular}


bioRxiv preprint doi: https://doi.org/10.1101/2021.04.05.438500; this version posted April 6, 2021. The copyright holder for this preprint (which was not certified by peer review) is the author/funder, who has granted bioRxiv a license to display the preprint in perpetuity. It is made available under aCC-BY 4.0 International license.

\begin{tabular}{|c|c|c|c|c|c|c|c|c|}
\hline 3 & ENO2 & Gamma-enolase & u & $d$ & & & + & [44] \\
\hline 2 & EPRS & Bifunctional glutamate/proline-tRNA ligase & u & & & & + & [45] \\
\hline 4 & ERO1L & ERO1-like protein alpha & & $d$ & Orf3a & & + & \\
\hline 4 & ETF1 & Eukaryotic peptide chain release factor subunit 1 & u & & & & + & \\
\hline 14 & EZR & Ezrin & u & $d$ & $\mathrm{~S}$ & & + & [46] \\
\hline 3 & FARSB & Phenylalanine-tRNA ligase beta subunit & & & & & + & [47] \\
\hline 19 & FASN & Fatty acid synthase & u & $d$ & & & + & [48] \\
\hline 2 & FDPS & Farnesyl pyrophosphate synthetase like- 4 protein & & $d$ & & & + & \\
\hline 2 & FEN1 & Flap endonuclease 1 & $\mathrm{u}$ & $d$ & & & + & \\
\hline 2 & FERMT3 & Fermitin family homolog 3 & $\mathrm{u}$ & & & & + & \\
\hline 11 & FKBP4 & Peptidyl-prolyl cis-trans isomerase FKBP4, FKBP-52 & & & Nsp12 & & + & [49] \\
\hline 2 & FKBP5 & $\begin{array}{l}\text { Peptidyl-prolyl cis-trans isomerase FKBP5 (FK506-binding } \\
\text { protein) }\end{array}$ & u & & & & + & \\
\hline 2 & FUBP1 & Far upstream element-binding protein 1 & $\mathrm{u}$ & $d$ & & & + & \\
\hline 2 & G6PD & Glucose-6-phosphate 1-dehydrogenase & u & $d$ & & & + & {$[50]$} \\
\hline 5 & GANAB & Neutral alpha-glucosidase $A B$ & & $d$ & $\begin{array}{c}\text { Orf6 } \\
\text { Orf8 } \\
\text { Orf9c }\end{array}$ & & + & {$[51]$} \\
\hline 6 & GAPDH & Glyceraldehyde-3-phosphate dehydrogenase & u & $d$ & Orf8 & & + & {$[52]$} \\
\hline 4 & GARS & Glycine-tRNA ligase, GARS1 & u & & & & + & [53] \\
\hline 2 & GART & Trifunctional purine biosynthetic protein adenosine-3 & & $d$ & Nsp15 & & + & \\
\hline 2 & GBE1 & 1,4-alpha-glucan-branching enzyme & u & & & & + & \\
\hline 8 & GDI1 & Rab GDP dissociation inhibitor alpha & u & $d$ & & & + & {$[54]$} \\
\hline 10 & GDI2 & Rab GDP dissociation inhibitor beta & u & $d$ & $\begin{array}{l}\text { Nsp12 } \\
\text { Orf9b }\end{array}$ & & + & [55] \\
\hline 2 & GGCT & $\begin{array}{l}\text { Gamma-glutamylcyclotransferase, cytochrome c-releasing } \\
\text { factor } 21\end{array}$ & u & & & & + & \\
\hline 3 & GLO1 & Lactoylglutathione lyase & & $d$ & Orf3 & & + & {$[56]$} \\
\hline 3 & GLRX3 & Glutaredoxin-3 & & $d$ & & & + & \\
\hline 10 & GLUD1 & Glutamate dehydrogenase 1 , mitochondrial & & & & & + & [57] \\
\hline 2 & GMFB & Glia maturation factor, beta & u & & & & + & \\
\hline 3 & GSPT1 & $\begin{array}{l}\text { Eukaryotic peptide chain release factor GTP-binding subunit } \\
\text { ERF3A }\end{array}$ & & & & & + & \\
\hline 3 & GSS & Glutathione synthetase & & $d$ & & & + & \\
\hline 2 & GTF2I & General transcription factor II-I & $\mathrm{u}$ & $d$ & & & + & \\
\hline 3 & H2AFV & Histone H2A.V, H2AZ2 & $\mathrm{u}$ & $d$ & & + & & {$[58]$} \\
\hline 2 & H2AFY2 & Core histone marco-H2A.1, MARCOH2A1 & & & & + & & [59] \\
\hline 3 & HARS & Histidine-tRNA ligase, cytoplasmic & & & & & + & [19] \\
\hline 3 & HDGF & Hepatoma-derived growth factor, hmg-1/2 & $\mathrm{u}$ & $d$ & & & + & {$[60]$} \\
\hline 5 & HIST1H1C & Histone $1.2, \mathrm{H} 1-2$ & $u$ & $d$ & Nsp8 & & + & {$[61]$} \\
\hline 2 & HIST1H2AB & Histone H2A type 1-B/E, H2AC4 & & $d$ & & + & & {$[62]$} \\
\hline 2 & HIST1H2BL & Histone $\mathrm{H} 2 \mathrm{~B}$ type $1-\mathrm{L}, \mathrm{H} 2 \mathrm{BC} 13$ & $\mathrm{u}$ & & & + & & [63] \\
\hline 14 & HIST1H4J & Histone $\mathrm{H} 4, \mathrm{H} 4 \mathrm{C} 1$ & & & & + & & [64] \\
\hline 9 & $\mathrm{HIST} 2 \mathrm{H} 2 \mathrm{BE}$ & Histone $\mathrm{H} 2 \mathrm{~B}$ type 2-E, $\mathrm{H} 2 \mathrm{BC} 21$ & $\mathrm{u}$ & $d$ & & + & & [65] \\
\hline 5 & HIST2H3A & Histone $\mathrm{H} 3.2, \mathrm{H} 3 \mathrm{C} 15$ & $\mathrm{u}$ & $d$ & & + & & [66] \\
\hline 4 & HMGB1 & High mobility group protein 1 -like 10 (hmg-1/10) & & $d$ & & & + & {$[60]$} \\
\hline 3 & HMGCS1 & Hydroxymethylglutaryl-CoA synthase, cytoplasmic & $\mathrm{u}$ & $d$ & & & + & \\
\hline 4 & HNRNPA1 & Heterogeneous nuclear ribonucleoprotein A1 & $\mathrm{u}$ & $d$ & & & + & [67] \\
\hline 8 & $\begin{array}{l}\text { HNRNPA2B } \\
1\end{array}$ & Heterogeneous nuclear ribonucleoproteins A2/B1 & u & $d$ & & & + & [68] \\
\hline 2 & HNRNPA3 & Heterogeneous nuclear ribonucleoprotein $\mathrm{A} 3$ & $\mathrm{u}$ & $d$ & & & + & [69] \\
\hline 2 & HNRNPAB & Heterogeneous nuclear ribonucleoprotein $A / B$ & & $d$ & & & + & [69] \\
\hline 3 & HNRNPC & Heterogeneous nuclear ribonucleoprotein C1/C2 & $\mathrm{u}$ & $d$ & & & + & [70] \\
\hline 5 & HNRNPCL1 & Heterogeneous nuclear ribonucleoprotein C-like 1 & & & & & + & [70] \\
\hline 5 & HNRNPD & Heterogeneous nuclear ribonucleoprotein D & & & & & + & [71] \\
\hline 2 & HNRNPDL & Heterogeneous nuclear ribonucleoprotein D-like & $\mathrm{u}$ & $d$ & & & + & [72] \\
\hline 3 & HNRNPF & Heterogeneous nuclear ribonucleoprotein $\mathrm{F}$ & & $d$ & & & + & [73] \\
\hline 2 & HNRNPH1 & Heterogeneous nuclear ribonucleoprotein $\mathrm{H}(\mathrm{hnrnp} \mathrm{h}$ ) & u & $d$ & & & + & {$[74]$} \\
\hline 9 & HNRNPK & $\begin{array}{l}\text { Heterogeneous nuclear ribonucleoprotein } \mathrm{K} \text { (transformation } \\
\text { up-regulated nuclear protein) }\end{array}$ & $\mathrm{u}$ & & & & + & [75] \\
\hline 5 & HNRNPR & Heterogeneous nuclear ribonucleoprotein $\mathrm{R}$ & $\mathrm{u}$ & $d$ & & & + & [76] \\
\hline 2 & HNRNPU & Heterogeneous nuclear ribonucleoprotein U & $u$ & $d$ & & & + & {$[77]$} \\
\hline 6 & HPRT1 & Hypoxanthine-guanine phosphoribosyltransferase & & & & & + & \\
\hline 16 & HSP90AA1 & $\begin{array}{l}\text { Heat shock protein HSP 90-alpha (hsp 86) (ny-ren-38 } \\
\text { antigen) }\end{array}$ & $\mathrm{u}$ & $d$ & & & & [78] \\
\hline 6 & HSP90AA2 & Heat shock protein HSP 90-alpha A2 & u & & & & + & [79] \\
\hline
\end{tabular}


bioRxiv preprint doi: https://doi.org/10.1101/2021.04.05.438500; this version posted April 6, 2021. The copyright holder for this preprint (which was not certified by peer review) is the author/funder, who has granted bioRxiv a license to display the preprint in perpetuity. It is made available under aCC-BY 4.0 International license.

\begin{tabular}{|c|c|c|c|c|c|c|c|}
\hline 16 & HSP90AB1 & Heat shock protein HSP 90-beta (hsp 84) (hsp 90) & $\mathrm{u}$ & $d$ & Nsp12 & + & [80] \\
\hline 19 & HSP90B1 & Endoplasmin, GRP94, tumor rejection antigen 1 & $\mathrm{u}$ & $d$ & $\begin{array}{l}\text { Orf3a } \\
\text { Orf9c }\end{array}$ & + & [79] \\
\hline 4 & HSPA4 & Heat shock 70 kda protein 4 & $\mathrm{u}$ & $d$ & & + & [81] \\
\hline 15 & HSPA5 & Endoplasmic reticulum chaperone, GRP78, BiP & $\mathrm{u}$ & $d$ & $\begin{array}{c}\text { S } \\
E \\
M \\
\text { Nsp2 } \\
\text { Nsp4 } \\
\text { Nsp6 } \\
\text { Orf3a } \\
\text { Orf7a } \\
\text { Orf7b }\end{array}$ & + & [82] \\
\hline 24 & HSPA8 & Heat shock cognate $71 \mathrm{kDa}$ protein & $\mathrm{u}$ & $d$ & $\begin{array}{l}\text { Nsp2 } \\
\text { Nsp12 }\end{array}$ & + & [83] \\
\hline 12 & HSPA9 & Stress-70 protein, mitochondrial (grp 75) & $\mathrm{u}$ & $d$ & $\mathrm{~N}$ & + & [84] \\
\hline 19 & HSPD1 & $60 \mathrm{kda}$ heat shock protein, mitochondrial matrix protein $\mathrm{p} 1$ & u & d & & + & [85] \\
\hline 4 & HSPH1 & Heat shock protein $105 \mathrm{kD}$ & $\mathrm{u}$ & & & + & [86] \\
\hline 2 & IDE & Insulin-degrading enzyme & & & $\begin{array}{c}\text { Nsp4 } \\
\text { Nsp12 } \\
\text { Nsp14 } \\
\text { Nsp15 } \\
\text { Nsp16 } \\
\text { Orf3b }\end{array}$ & + & \\
\hline 2 & IDH3A & $\begin{array}{l}\text { Isocitrate dehydrogenase [NAD] subunit alpha, } \\
\text { mitochondrial }\end{array}$ & & & & + & \\
\hline 6 & ILF2 & Interleukin enhancer-binding factor 2 & $\mathrm{u}$ & & & + & [87] \\
\hline 6 & IPO5 & Importin-5, KPNB3, RANBP5 & & & & + & [88] \\
\hline 3 & IPO7 & Importin-7, RANBP7 & & & $\begin{array}{l}\text { Nsp6 } \\
\text { Orf9c }\end{array}$ & + & [89] \\
\hline 8 & IQGAP1 & Ras GTPase-activating-like protein IQGAP1 & $\mathrm{u}$ & & & + & [90] \\
\hline 4 & KARS & Lysine-tRNA ligase, KARS1 & & & Nsp7 & + & [45] \\
\hline 3 & KHSRP & $\begin{array}{l}\text { Far upsteam element-binding protein } 2 \text { (KH-type splicing } \\
\text { regulatory protein) }\end{array}$ & $\mathrm{u}$ & $d$ & & + & \\
\hline 2 & KPNA2 & Importin subunit alpha-1 & & $d$ & Orf6 & + & \\
\hline 11 & KPNB1 & Importin subunit beta-1 & & & & + & [88] \\
\hline 30 & LCP1 & Plastin-2 (I-plastin) (lymphocyte cytosolic protein 1) & $\mathrm{u}$ & $d$ & & + & [91] \\
\hline 7 & LDHA & $\begin{array}{l}\text { L-lactate dehydrogenase A chain (proliferation-inducing } \\
\text { gene } 19 \text { protein) }\end{array}$ & $\mathrm{u}$ & $d$ & Nsp12 & + & [92] \\
\hline 10 & LDHB & L-lactate dehydrogenase $B$ chain & u & $d$ & $\begin{array}{l}\text { Nsp12 } \\
\text { Nsp7 }\end{array}$ & + & [93] \\
\hline 16 & LRPPRC & leucine-rich PPR motif-containing protein & & d & & + & [94] \\
\hline 7 & MCM2 & DNA replication licensing factor $\mathrm{MCM} 2$ & & $d$ & & + & [95] \\
\hline 3 & MCM3 & $\begin{array}{l}\text { DNA replication licensing factor } \mathrm{mcm} 3 \text { (dna polymerase } \\
\text { alpha holoenzyme-associated protein p1)(p102 protein) } \\
\text { (p1-mcm3) }\end{array}$ & $\mathrm{u}$ & $d$ & & + & [95] \\
\hline 3 & MCM4 & $\begin{array}{l}\text { DNA replication licensing factor } \mathrm{mcm} 4 \text { (cdc21 homolog) (p1- } \\
\text { cdc21) }\end{array}$ & $\mathrm{u}$ & $d$ & & + & [95] \\
\hline 2 & MCM6 & DNA replication licensing factor $\mathrm{mcm} 6(\mathrm{p} 105 \mathrm{mcm})$ & u & $d$ & & + & [95] \\
\hline 2 & ME2 & NAD-dependent malic enzyme, mitochondrial & $\mathrm{u}$ & d & Nsp15 & + & \\
\hline 6 & MSN & Moesin & $\mathrm{u}$ & & $\begin{array}{c}\text { S } \\
\text { Nsp6 } \\
\text { Orf3 }\end{array}$ & + & [96] \\
\hline 2 & MYG1 & UPF0160 protein MYG1, mitochondrial, C12orf10 & & & & + & \\
\hline 4 & MZB1 & $\begin{array}{l}\text { Marginal zone B-and B1-cell-specifc protein (Proapoptotic } \\
\text { caspase adapter protein, plasma cell-induced resident } \\
\text { protein) }\end{array}$ & & & & + & \\
\hline 3 & NAA15 & $\begin{array}{l}\mathrm{N} \text {-alpha-acetyltransferase } 15, \text { NatA auxiliary subunit (NMDA } \\
\text { receptor-regulated protein, NARG1) }\end{array}$ & & $d$ & & + & \\
\hline 2 & NAA25 & $\begin{array}{l}\mathrm{N} \text {-alph-acetyltransferase } 25, \text { NatB auxiliary subunit (TPR } \\
\text { repeat-containing protein C12orf30) }\end{array}$ & & & & + & \\
\hline 3 & NACA & $\begin{array}{l}\text { Nascent polypeptide-associated complex subunit alpha } \\
\text { (nac-alpha) }\end{array}$ & $\mathrm{u}$ & $d$ & & + & [97] \\
\hline 7 & NAP1L1 & $\begin{array}{l}\text { Nucleosome assembly protein 1-like } 1 \text { (nap-1-related } \\
\text { protein) (hnrp) }\end{array}$ & & $d$ & & + & \\
\hline 4 & NAP1L4 & $\begin{array}{l}\text { Nucleosome assembly protein 1-like } 4 \text { (nucleosome } \\
\text { assembly protein 2) }\end{array}$ & u & d & & + & \\
\hline
\end{tabular}


bioRxiv preprint doi: https://doi.org/10.1101/2021.04.05.438500; this version posted April 6, 2021. The copyright holder for this preprint (which was not certified by peer review) is the author/funder, who has granted bioRxiv a license to display the preprint in perpetuity. It is made available under aCC-BY 4.0 International license.

\begin{tabular}{|c|c|c|c|c|c|c|c|c|}
\hline 5 & NARS & Asparagine-tRNA ligase, cytoplasmic, NARS1 & & $d$ & & & + & [98] \\
\hline 4 & NASP & $\begin{array}{l}\text { Nuclear autoantigenic sperm protein (histone binding } \\
\text { protein) }\end{array}$ & $\mathrm{u}$ & d & & & + & [99] \\
\hline 12 & $\mathrm{NCL}$ & Nucleolin & $\mathrm{u}$ & $d$ & & & + & {$[100]$} \\
\hline 8 & NME1 & Nucleoside diphosphate kinase $\mathrm{A}$ & & $d$ & & & + & {$[101]$} \\
\hline 15 & NPEPPS & Puromycin-sensitive aminopeptidase & & & & & + & \\
\hline 4 & NPM1 & Nucleophosmin & $\mathrm{u}$ & $d$ & Orf9c & & + & {$[102]$} \\
\hline 3 & NSFL1C & NSFL1 cofactor $\mathrm{p} 47$ & $\mathrm{u}$ & & & & + & \\
\hline 8 & NUDC & $\begin{array}{l}\text { Nuclear migration protein nudC (nuclear distribution } \\
\text { protein c homolog) }\end{array}$ & & $d$ & Nsp12 & & + & \\
\hline 2 & NUDT21 & Cleavage and polyadenylation specificity factor subunit 5 & & $d$ & & & + & \\
\hline 2 & NUDT3 & Diphosphoinositol polyphosphate phosphohydrolase & & & & & + & \\
\hline 4 & NUDT5 & $\begin{array}{l}\text { ADP-sugar pyrophosphatase (nucleoside diphosphate-linked } \\
\text { moiety x motif 5) (nudix motif 5) }\end{array}$ & & $d$ & & & + & \\
\hline 2 & OTUB1 & Ubiquitin thioesterase protein OTUB1 & & & & & + & \\
\hline 5 & P4HB & $\begin{array}{l}\text { Protein disulfide-isomerase (cellular thyroid hormone- } \\
\text { binding protein) ( } 555)\end{array}$ & $\mathrm{u}$ & $d$ & $\begin{array}{l}\text { Nsp7 } \\
\text { Orf3b }\end{array}$ & & + & {$[103]$} \\
\hline 14 & PA2G4 & Proliferation-associated protein 2G4 & $\mathrm{u}$ & & & & + & \\
\hline 9 & PABPC1 & Polyadenylate-binding protein 1 & & $d$ & $\mathrm{~N}$ & + & & {$[104]$} \\
\hline 2 & PAFAH1B2 & Platelet-activating factor acetylhydrolase IB subunit beta & $\mathrm{u}$ & $d$ & & & + & \\
\hline 2 & PAFAH1B3 & Platelet-activating factor acetylhydrolase IB subunit gamma & $\mathrm{u}$ & & $\begin{array}{l}\text { Nsp12 } \\
\text { Nsp5 } \\
\text { Orf3b }\end{array}$ & & + & \\
\hline 6 & PAICS & Multifunctional protein ADE2 & & d & & & + & \\
\hline 2 & PARP1 & Poly [ADP-ribose] polymerase 1 & $\mathrm{u}$ & $d$ & & & + & \\
\hline 8 & PCNA & Proliferating cell nuclear antigen (cyclin) & $\mathrm{u}$ & $d$ & & & + & [52] \\
\hline 2 & PDCD10 & Programmed cell death protein 10 & & & & & + & \\
\hline 21 & PDIA3 & Protein disulfide-isomerase $\mathrm{A} 3$ & u & $d$ & $\begin{array}{c}\mathrm{M} \\
\text { Orf3a } \\
\text { Orf3b } \\
\text { Orf8 } \\
\text { Orf9c }\end{array}$ & & + & {$[105]$} \\
\hline 8 & PDIA4 & Protein disulfide-isomerase A4 (protein erp-72) (erp72) & $\mathrm{u}$ & $d$ & $\begin{array}{l}\text { Nsp16 } \\
\text { Nsp7 } \\
\text { Orf3b }\end{array}$ & & + & {$[106]$} \\
\hline 5 & PDIA6 & $\begin{array}{l}\text { Protein disulfide-isomerase A6 (protein disulfide isomerase } \\
\text { p5) (thioredoxin domain-containing protein 7) }\end{array}$ & $\mathrm{u}$ & $d$ & & & + & {$[103]$} \\
\hline 7 & PFAS & Phosphoribosylformylglycinamidine synthase & & & $\begin{array}{c}\text { Nsp12 } \\
\text { Nsp15 } \\
\text { Nsp16 } \\
\text { Nsp7 }\end{array}$ & & + & \\
\hline 3 & PFDN2 & Prefoldin subunit 2 & $\mathrm{u}$ & & $\begin{array}{l}\text { Nsp12 } \\
\text { Nsp15 } \\
\text { Orf10 }\end{array}$ & & + & {$[107]$} \\
\hline 2 & PFDN3 & $\begin{array}{l}\text { Prefoldin subunit 3, von hippel-lindau-binding protein } 1 \text {, } \\
\text { VBP1 }\end{array}$ & & $d$ & $\begin{array}{l}\text { Nsp12 } \\
\text { Nsp15 }\end{array}$ & & + & \\
\hline 9 & PFN1 & Profilin-1 (profilin i) & $\mathrm{u}$ & $d$ & & & + & [95] \\
\hline 4 & PGAM1 & Phosphoglycerate mutase 1 & $\mathrm{u}$ & $d$ & & & + & {$[108]$} \\
\hline 4 & PGAM2 & Phosphoglycerate mutase 2 & & & & & + & \\
\hline 3 & PGLS & 6-phosphogluconolactonase & $\mathrm{u}$ & & & & + & \\
\hline 3 & PHGDH & D-3-phosphoglycerate dehydrogenase & $\mathrm{u}$ & $d$ & & & + & {$[109]$} \\
\hline 10 & PLCG2 & $\begin{array}{l}\text { 1-phosphatidylinositol-4,5-bisphosphate phosphodiesterase } \\
\text { gamma-2 }\end{array}$ & $\mathrm{u}$ & & & & + & \\
\hline 2 & PMPCB & Mitochondrial-processing peptidase subunit beta & & $d$ & M & & + & \\
\hline 8 & PPA1 & Inorganic pyrophosphatase & $\mathrm{u}$ & & Orf3 & & + & {$[110]$} \\
\hline 3 & PPAT & Amidophosphoribosyltransferase & & $d$ & & & + & \\
\hline 6 & PPIB & Peptidyl-prolyl cis-trans isomerase B & u & $d$ & Orf8 & & + & {$[111]$} \\
\hline 2 & PPP1R7 & $\begin{array}{l}\text { Protein phosphatase } 1 \text { regulatory subunit } 7 \text { (protein } \\
\text { phosphatase } 1 \text { regulatory subunit } 7 \text { ) (protein phosphatase } 1 \\
\text { regulatory subunit 22) }\end{array}$ & $\mathrm{u}$ & & & & + & \\
\hline 3 & PPP2R1A & $\begin{array}{l}\text { Serine/threonine-protein phosphatase } 2 \mathrm{~A} 65 \mathrm{kDa} \text { regulatory } \\
\text { subunit A alpha isoform }\end{array}$ & & $d$ & & & + & \\
\hline 3 & PRDX1 & Peroxiredoxin-1 & u & $d$ & & & + & {$[112]$} \\
\hline 5 & PRDX3 & Thioredoxin-dependent peroxide reductase, mitochondrial & $\mathrm{u}$ & d & & & + & {$[113]$} \\
\hline 2 & PRKCSH & Glucosidase 2 subunit beta (protein kinase c substrate) & & $d$ & $\begin{array}{c}\text { S } \\
\text { Nsp6 } \\
\text { Orf3 }\end{array}$ & & + & \\
\hline
\end{tabular}


bioRxiv preprint doi: https://doi.org/10.1101/2021.04.05.438500; this version posted April 6, 2021. The copyright holder for this preprint (which was not certified by peer review) is the author/funder, who has granted bioRxiv a license to display the preprint in perpetuity. It is made available under aCC-BY 4.0 International license.

\begin{tabular}{|c|c|c|c|c|c|c|c|c|}
\hline & & & & & Orf3a & & & \\
\hline 2 & PRMT1 & $\begin{array}{l}\text { Protein arginine } \mathrm{n} \text {-methyltransferase } 1 \text { (hnRNP } \\
\text { methyltransferase-like } 2 \text { isoform (ec 2.1.1.-) (interferon } \\
\text { receptor 1-bound protein } 4 \text { ) }\end{array}$ & & $d$ & & & + & [114] \\
\hline 2 & PRPSAP2 & $\begin{array}{l}\text { Phosphoribosyl pyrophosphate synthetase-associated } \\
\text { protein } 2\end{array}$ & $\mathrm{u}$ & & & & + & \\
\hline 3 & PSMA1 & Proteasome subunit alpha type- 1 & & $d$ & Orf3b & & + & [115] \\
\hline 2 & PSMA2 & Proteasome subunit alpha type-2 & & $d$ & & & + & \\
\hline 6 & PSMA3 & Proteasome subunit alpha type- 3 (macropain subunit c8) & u & $d$ & $\begin{array}{c}\text { Nsp2 } \\
\text { Nsp4 } \\
\text { Nsp7 } \\
\text { Nsp10 } \\
\text { Nsp12 }\end{array}$ & & + & [116] \\
\hline 5 & PSMA4 & Proteasome subunit alpha type-4 (C9) & $\mathrm{u}$ & & & & + & [117] \\
\hline 5 & PSMA5 & Proteasome subunit alpha type- 5 (macropain zeta chain) & $\mathrm{u}$ & & Orf3b & & + & [118] \\
\hline 8 & PSMA6 & Proteasome subunit alpha type- 6 & $\mathrm{u}$ & $d$ & Orf3b & & + & \\
\hline 4 & PSMA7 & Proteasome subunit alpha type-7 & $\mathrm{u}$ & $d$ & & & + & [119] \\
\hline 5 & PSMB1 & Proteasome subunit beta type-1 & & & & & + & [120] \\
\hline 3 & PSMB3 & Proteasome subunit beta type- 3 (proteasome theta chain) & & $d$ & Orf3b & & + & [116] \\
\hline 7 & PSMB4 & $\begin{array}{l}\text { Proteasome subunit beta type- } 4 \text { (proteasome beta chain) } \\
\text { (macropain beta chain) (multicatalytic endopeptidase } \\
\text { complex beta chain) }\end{array}$ & & & Orf3b & & + & \\
\hline 2 & PSMB6 & $\begin{array}{l}\text { Proteasome subunit beta type- } 6 \text { (proteasome delta } \\
\text { chain)(multicatalytic endopeptidase complex delta chain) }\end{array}$ & & $d$ & Orf3b & & + & \\
\hline 3 & PSMB7 & Proteasome subunit beta type-7 (proteasome subunit z) & & $d$ & & & + & [121] \\
\hline 3 & PSMB8 & Proteasome subunit beta type- 8 & $\mathrm{u}$ & $d$ & & & + & \\
\hline 4 & PSMB9 & Proteasome subunit beta type- 9 & $\mathrm{u}$ & $\mathrm{d}$ & & & + & \\
\hline 2 & PSMC3 & $26 \mathrm{~S}$ protease regulatory subunit $6 \mathrm{~A}$ & & $\mathrm{~d}$ & Orf6 & & + & \\
\hline 5 & PSMD1 & $26 \mathrm{~S}$ proteasome non-ATPase regulatory subunit 1 & $\mathrm{u}$ & $d$ & $\begin{array}{l}\text { Nsp7 } \\
\text { Orf6 } \\
\text { Orf8 }\end{array}$ & & + & \\
\hline 9 & PSMD11 & Proteasome $26 \mathrm{~S}$ non-ATPase regulatory subunit 11 & $\mathrm{u}$ & & & & + & \\
\hline 3 & PSMD12 & $26 \mathrm{~S}$ proteasome non-ATPase regulatory subunit 12 & & $d$ & & & + & \\
\hline 2 & PSMD14 & $26 \mathrm{~S}$ proteasome non-ATPase regulatory subunit 14 & & & & & + & \\
\hline 8 & PSMD3 & $26 \mathrm{~S}$ proteasome non-ATPase regulatory subunit 3 & & $d$ & & & + & \\
\hline 3 & PSMD6 & $26 \mathrm{~S}$ proteasome non-ATPase regulatory subunit 6 & & & & & + & \\
\hline 11 & PSME1 & Proteasome activator complex subunit 1 & $\mathrm{u}$ & & Nsp15 & & + & \\
\hline 8 & PSME2 & Proteasome activator complex subunit 2 & $\mathrm{u}$ & & & & + & \\
\hline 4 & PSME3 & Proteasome activator complex subunit 3 & & $d$ & Nsp16 & & + & {$[122]$} \\
\hline 2 & PSPH & Phosphoserine phosphatase & & & & & + & \\
\hline 3 & PTBP1 & Polypyrimidine tract-binding protein 1 & $\mathrm{u}$ & $d$ & & & + & {$[123]$} \\
\hline 2 & РTBP3 & $\begin{array}{l}\text { Polypyrimidine tract-binding protein (cDNA FLJ51619, highly } \\
\text { similar to Regulator of differentiation) ROD1 }\end{array}$ & $\mathrm{u}$ & $d$ & & & + & \\
\hline 2 & PTGES3 & $\begin{array}{l}\text { Prostaglandin E synthase } 3 \text { (telomerase-binding protein } \\
\text { p23) (hsp90 co- chaperone) (progesterone rec) }\end{array}$ & & $d$ & & & + & \\
\hline 2 & PTPN6 & Tyrosine-protein phosphatase non-receptor type 6 & $\mathrm{u}$ & $d$ & & & + & \\
\hline 2 & PUS1 & tRNA pseudouridine synthase $A$ & & & & & + & \\
\hline 5 & RAB7A & Ras-related protein Rab-7a & $\mathrm{u}$ & $d$ & $\begin{array}{l}\text { Nsp7 } \\
\text { Orf3 } \\
\text { Orf7b }\end{array}$ & & + & \\
\hline 2 & RAD23A & UV excision repair protein RAD23 homolog A & & $d$ & & & + & [124] \\
\hline 3 & RANBP1 & RanBP & $\mathrm{u}$ & $d$ & & & + & \\
\hline 2 & RANBP6 & Ran-binding protein 6 & & $d$ & Orf7a & & + & \\
\hline 7 & RDX & Radixin, isoform CRA (actin binding to plasma membrane) & $\mathrm{u}$ & d & Nsp13 & & + & [125] \\
\hline 2 & RPL10A & $60 S$ ribosomal protein L10a & & & & + & & \\
\hline 2 & RPL11 & $60 S$ ribosomal protein $\mathrm{L} 11$ & $\mathrm{u}$ & & & & + & \\
\hline 2 & RPL15 & $60 S$ ribosomal protein L15 & & $d$ & & + & & \\
\hline 2 & RPL22 & $\begin{array}{l}\text { 60s ribosomal protein L22 (Epstein-Barr virus small rna- } \\
\text { associated protein)(heparin-binding protein hbp15) }\end{array}$ & & $d$ & & & + & {$[121]$} \\
\hline 4 & RPLPO & 60 s acidic ribosomal protein $\mathrm{PO}$ & $\mathrm{u}$ & $d$ & & + & & {$[126]$} \\
\hline 2 & RPS15A & 40 s ribosomal protein $\mathrm{S} 15 \mathrm{a}$ & $\mathrm{u}$ & & & & & \\
\hline 2 & RPS25 & 40 S ribosomal protein $\$ 25$ & $\mathrm{u}$ & $d$ & Orf8 & & + & \\
\hline 3 & RPS27A & Ubiquitin-40S ribosomal protein S27a & $\mathrm{u}$ & $d$ & $\begin{array}{c}\text { S } \\
\text { Nsp4 }\end{array}$ & + & & {$[121]$} \\
\hline 6 & RPS3 & 40 S ribosomal protein S3 & $\mathrm{u}$ & $d$ & Orf8 & & + & {$[127]$} \\
\hline 3 & RPS3A & $40 \mathrm{~S}$ ribosomal protein S3a & $\mathrm{u}$ & $d$ & Orf8 & & + & \\
\hline
\end{tabular}


bioRxiv preprint doi: https://doi.org/10.1101/2021.04.05.438500; this version posted April 6, 2021. The copyright holder for this preprint (which was not certified by peer review) is the author/funder, who has granted bioRxiv a license to display the preprint in perpetuity. It is made available under aCC-BY 4.0 International license.

\begin{tabular}{|c|c|c|c|c|c|c|c|c|}
\hline 3 & RPS7 & 40S ribosomal protein $\mathrm{S7}$ & $\mathrm{u}$ & $d$ & & & + & \\
\hline 5 & RPSA & $\begin{array}{l}\text { similar to } 40 \mathrm{~S} \text { ribosomal protein SA ( } \mathrm{p} 40)(34 / 67 \mathrm{kDa} \\
\text { laminin receptor) (Colon carcinoma laminin-binding protein) } \\
\text { (NEM/1CHD4) (Multidrug resistance-associated protein } \\
\text { MGr1-Ag), RPSAP12 }\end{array}$ & & & & & + & \\
\hline 6 & RUVBL1 & $\begin{array}{l}\text { RuvB-like } 1 \text {, tata box-binding protein-interacting protein, } \\
\text { nuclear matrix protein } 238\end{array}$ & & & $\begin{array}{l}\text { Nsp1 } \\
\text { Nsp7 } \\
\text { Nsp12 } \\
\text { Orf9b }\end{array}$ & & + & [128] \\
\hline 5 & RUVBL2 & RuvB-like 2 & & $d$ & $\begin{array}{l}\text { Nsp1 } \\
\text { Nsp7 } \\
\text { Nsp12 }\end{array}$ & & + & [129] \\
\hline 2 & SARS & Serine-tRNA ligase, cytoplasmic, SARS1 & & & Nsp15 & & + & \\
\hline 2 & SEPT11 & Septin-11 & & $d$ & & & + & \\
\hline 2 & SEPT2 & Septin-2, NEDD5, DIFF6 & & & & & + & {$[130]$} \\
\hline 3 & SEPT7 & Septin-7 & & $d$ & & & + & [131] \\
\hline 8 & SERPINB9 & Serpin B9 & $\mathrm{u}$ & $d$ & & & + & \\
\hline 2 & SERPINC1 & Antithrombin-III & $\mathrm{u}$ & & & & + & \\
\hline 6 & SET & $\begin{array}{l}\text { Protein SET (phosphatase 2a inhibitor i2pp2a) (i-2pp2a) } \\
\text { (template- activating factor i) (taf-i) (hla-dr-associated } \\
\text { protein ii) (phapii) }\end{array}$ & u & $d$ & & & + & [132] \\
\hline 3 & SF3B3 & Splicing factor $3 \mathrm{~B}$ subunit 3 & & & & & + & [133] \\
\hline 2 & SFPQ & Splicing factor, proline- and glutamine-rich & $\mathrm{u}$ & $d$ & & & + & [134] \\
\hline 3 & SGTA & $\begin{array}{l}\text { Small glutamine-rich tetratricopeptide repeat-containing } \\
\text { protein alpha }\end{array}$ & u & $d$ & M & & + & \\
\hline 2 & SHMT1 & Serine hydroxymethyltransferase, cytosolic & & $d$ & & & + & \\
\hline 9 & SHMT2 & Serine hydroxymethyltransferase, mitochondrial & & $d$ & & & + & \\
\hline 2 & SLIRP & $\begin{array}{l}\text { SRA stem-loop-interacting RNA-binding protein, } \\
\text { mitochondrial }\end{array}$ & u & $d$ & & & + & \\
\hline 8 & SND1 & Staphylococcal nuclease domain-containing protein 1 & $\mathrm{u}$ & $d$ & & & + & \\
\hline 2 & SNRNP70 & U1 small nuclear ribonucleoprotein $70 \mathrm{kDa}$ & $\mathrm{u}$ & $d$ & & & + & {$[135]$} \\
\hline 3 & SNRPA & U1 small nuclear ribonucleoprotein $\mathrm{A}$ & $\mathrm{u}$ & & & & + & [136] \\
\hline 3 & SNRPA1 & U2 small nuclear ribonucleoprotein $A^{\prime}$ & & & & & + & [137] \\
\hline 2 & SNRPD1 & Small nuclear ribonucleoprotein Sm D1 & $\mathrm{u}$ & & & & + & [138] \\
\hline 2 & SNRPD2 & Small nuclear ribonucleoprotein Sm D2 & & $d$ & & & + & [139] \\
\hline 2 & SNRPD3 & $\begin{array}{l}\text { Small nuclear ribonucleoprotein Sm d3 (snrnp core protein } \\
\text { d3) (sm-d3) }\end{array}$ & & $d$ & & + & & [138] \\
\hline 2 & SNRPE & Small nuclear ribonucleoprotein $\mathrm{E}$ & & $d$ & & & + & {$[140]$} \\
\hline 2 & SPTAN1 & Spectrin alpha chain, non-erythrocytic 1 & $\mathrm{u}$ & $d$ & & & + & [141] \\
\hline 3 & SRM & Spermidine synthase & & $d$ & & & + & \\
\hline 3 & SRP14 & Signal recognition particle $14 \mathrm{kDa}$ protein & $\mathrm{u}$ & $d$ & $\begin{array}{l}\text { Nsp13 } \\
\text { Orf8 }\end{array}$ & & + & \\
\hline 3 & SRSF1 & $\begin{array}{l}\text { Serine/argine-rich splicing factor } 1 \text { (Isoform ASF-1 of } \\
\text { Splicing factor, arginine/serine-rich }\end{array}$ & $\mathrm{u}$ & $d$ & & & + & [142] \\
\hline 3 & SRSF2 & Arginine/serine-rich splicing factor 2, SFRS2 & $\mathrm{u}$ & $d$ & & & + & [143] \\
\hline 3 & SSB & $\begin{array}{l}\text { Lupus La protein (Sjoegren syndrome type b antigen) } \\
\text { (La/SSB) }\end{array}$ & $\mathrm{u}$ & $d$ & & & + & [144] \\
\hline 4 & SSBP1 & Single-stranded DNA-binding protein, mitochondrial & & & $\mathrm{N}$ & + & & \\
\hline 4 & ST13 & $\begin{array}{l}\text { Hsc70-interacting protein (hip) (suppression of } \\
\text { tumorigenicity protein 13) (putative tumor suppressor st13) } \\
\text { (protein fam10a1) (progesterone receptor-associate) }\end{array}$ & $\mathrm{u}$ & & $\begin{array}{c}\text { Nsp12 } \\
\text { Orf3b } \\
\text { Orf6 } \\
\text { Orf8 } \\
\text { Orf10 }\end{array}$ & & + & {$[145]$} \\
\hline 3 & STIP1 & Stress-induced-phosphoprotein 1 & $\mathrm{u}$ & $d$ & $\begin{array}{l}\text { Nsp12 } \\
\text { Orf3a } \\
\text { Orf8 } \\
\text { E }\end{array}$ & & + & \\
\hline 2 & SUGT1 & $\begin{array}{l}\text { Protein SGT1 homolog (Suppressor of G2 allele of SKP1 } \\
\text { homolog) }\end{array}$ & u & & $\begin{array}{l}\text { Nsp12 } \\
\text { Nsp15 }\end{array}$ & & + & \\
\hline 2 & SWAP70 & Switch-associated protein 70 & & $d$ & Nsp2 & & + & \\
\hline 5 & SYNCRIP & Heterogeneous nuclear ribonucleoprotein $\mathrm{Q}$ & & $d$ & & & + & \\
\hline 2 & TALDO1 & Transaldolase & $\mathrm{u}$ & $d$ & & & + & {$[146]$} \\
\hline 3 & TBCA & Tubulin-specific chaperone A & & & Nsp11 & & + & \\
\hline 3 & TCL1A & T-cell leukemia/lymphoma protein $1 \mathrm{~A}$ & $\mathrm{u}$ & $d$ & & & + & \\
\hline 7 & TCP1 & T-complex protein 1 subunit alpha (tcp-1-alpha) (cct-alpha) & & d & Orf10 & & + & [23] \\
\hline 10 & TLN1 & Talin-1 & $\mathrm{u}$ & $d$ & & & + & [147] \\
\hline 5 & TNPO1 & Transportin-1 & & & & & + & \\
\hline
\end{tabular}


bioRxiv preprint doi: https://doi.org/10.1101/2021.04.05.438500; this version posted April 6, 2021. The copyright holder for this preprint (which was not certified by peer review) is the author/funder, who has granted bioRxiv a license to display the preprint in perpetuity. It is made available under aCC-BY 4.0 International license.

\begin{tabular}{|c|c|c|c|c|c|c|c|c|}
\hline 2 & TOP1 & DNA topoisomerase 1 (Scl 70) & u & & & + & & [148] \\
\hline 5 & TPM1 & Tropomyosin alpha-1 chain isoform & $\mathrm{u}$ & $d$ & Nsp9 & & + & [149] \\
\hline 6 & TPM3 & Tropomyosin alpha-3 chain (tropomyosin gamma) & $\mathrm{u}$ & $d$ & & & + & [150] \\
\hline 5 & TPM4 & Tropomyosin alpha-4 chain & u & $d$ & & & + & [151] \\
\hline 4 & TPP2 & Tripeptidyl-peptidase 2 & & & & & + & \\
\hline 3 & TTLL12 & Tubulin-tyrosine ligase-like protein 12 & & $d$ & & & + & [152] \\
\hline 2 & TTLL3 & Tubulin monoglycylase TTLL3 & $\mathrm{u}$ & & & & + & \\
\hline 4 & TUBA1C & TUBA1C protein & $\mathrm{u}$ & $d$ & & + & & [153] \\
\hline 12 & TUBA4A & Tubulin alpha-4A chain & $\mathrm{u}$ & $d$ & & & + & [154] \\
\hline 5 & TUBB & Tubulin beta chain & $\mathrm{u}$ & $d$ & & & + & [155] \\
\hline 4 & TUBB1 & Tubulin beta- 1 chain & & & & & + & [156] \\
\hline 2 & TUBB4 & Tubulin beta- 3 chain, beta- 4 chain & $\mathrm{u}$ & $d$ & & & + & [157] \\
\hline 12 & TUBB4B & Tubulin beta-4B chain (Tubulin beta- $2 \mathrm{C}$ chain) & $\mathrm{u}$ & $d$ & & & + & [156] \\
\hline 2 & TXNDC17 & Thioredoxin domain-containing protein 17 & $\mathrm{u}$ & d & & & + & \\
\hline 4 & TXNRD1 & Thioredoxin reductase 1 , cytoplasmic & $\mathrm{u}$ & $d$ & & & + & [158] \\
\hline 2 & U2AF2 & Splicing factor U2AF $65 \mathrm{kDa}$ subunit & & $d$ & & & + & \\
\hline 7 & UBA1 & $\begin{array}{l}\text { Ubiquitin-like modifier-activating enzyme } 1 \text { (Ubiquitin- } \\
\text { activating enzyme E1) }\end{array}$ & $\mathrm{u}$ & $d$ & & & + & [159] \\
\hline 2 & UBA6 & Ubiquitin-like modifier-activating enzyme 6 & & & Nsp7 & & + & \\
\hline 2 & UBE2K & Ubiquitin-conjugating enzyme E2 K & & & & & + & \\
\hline 3 & USP5 & Ubiquitin carboxyl-terminal hydrolase 5 & $\mathrm{u}$ & $d$ & & & + & \\
\hline 3 & VARS1 & Valine-tRNA ligase & & & & & + & \\
\hline 12 & VCP & $\begin{array}{l}\text { Transitional endoplasmic reticulum ATPase (valosin- } \\
\text { containing protein) }\end{array}$ & u & $d$ & & & + & [160] \\
\hline 10 & VIM & Vimentin & $\mathrm{u}$ & $d$ & & + & & [161] \\
\hline 6 & WARS & Tryptophan-tRNA ligase, cytoplasmic, WARS1 & $\mathrm{u}$ & $d$ & & & + & [162] \\
\hline 2 & XPNPEP1 & Xaa-Pro aminopeptidase 1 & & d & & & + & \\
\hline 4 & XPO1 & Exportin-1 & & & $\begin{array}{l}\text { Nsp4 } \\
\text { Orf7a }\end{array}$ & & + & \\
\hline 5 & ХРОТ & Exportin-T (trna exportin) (exportin(trna)) & $\mathrm{u}$ & & Orf7a & & + & \\
\hline 3 & XRCC5 & $\begin{array}{l}\text { X5-ray repair cross-complementing protein 5, lupus ku86 } \\
\text { ku80 autoantigen }\end{array}$ & & $d$ & & & + & [163] \\
\hline 9 & XRCC6 & X-ray repair cross-complementing protein 6 (ku70) & u & d & & & + & [164] \\
\hline 6 & YARS & Tyrosine-tRNA ligase, cytoplasmic, YARS1 & $\mathrm{u}$ & $d$ & & & + & [165] \\
\hline 5 & YWHAB & $\begin{array}{l}\text { 14-3-3 protein beta/alpha (protein kinase c inhibitor protein } \\
\text { 1) }\end{array}$ & $\mathrm{u}$ & $d$ & & & + & \\
\hline 12 & YWHAE & 14-3-3 protein epsilon & $\mathrm{u}$ & $d$ & & & + & [166] \\
\hline 3 & YWHAG & 14-3-3 protein gamma & $\mathrm{u}$ & $d$ & & & + & [166] \\
\hline 3 & YWHAH & 14-3-3 protein eta (protein as 1 ) & & $d$ & & & + & [167] \\
\hline 3 & YWHAQ & 14-3-3 protein theta & $\mathrm{u}$ & $d$ & & & + & [168] \\
\hline 7 & YWHAZ & 14-3-3 protein zeta/delta & $\mathrm{u}$ & $d$ & & & + & [169] \\
\hline 2 & ZPR1 & Zinc finger protein ZPR1 & $\mathrm{u}$ & $d$ & & & + & [170] \\
\hline
\end{tabular}




\section{References for Table 1}

1. Saunders RD, Nakajima ST, Rai SN, Pan J, Gercel-Taylor C, Taylor DD. Alterations in antibody subclass immune reactivity to trophoblast-derived fetal fibronectin and a2-macroglobulin in women with recurrent pregnancy loss. Am J Reprod Immunol. 2012;68(5):438-49. Epub 2012/09/01. doi: 10.1111/j.16000897.2012.01182.x. PubMed PMID: 22935024.

2. Petrohai A, Nagy G, Bosze S, Hudecz F, Zsiros E, Paragh G, et al. Detection of citrate synthase-reacting autoantibodies after heart transplantation: an epitope mapping study. Transplant international : official journal of the European Society for Organ Transplantation. 2005;17(12):834-40. Epub 2005/02/16. doi: 10.1007/s00147004-0794-4. PubMed PMID: 15711981.

3. Mande PV, Parikh FR, Hinduja I, Zaveri K, Vaidya R, Gajbhiye R, et al. Identification and validation of candidate biomarkers involved in human ovarian autoimmunity. Reprod Biomed Online. 2011;23(4):471-83. doi: 10.1016/j.rbmo.2011.06.013. PubMed PMID: 21890413.

4. van Beers JJ, Schwarte CM, Stammen-Vogelzangs J, Oosterink E, Bozic B, Pruijn GJ. The rheumatoid arthritis synovial fluid citrullinome reveals novel citrullinated epitopes in apolipoprotein $\mathrm{E}$, myeloid nuclear differentiation antigen, and beta-actin. Arthritis and rheumatism. 2013;65(1):69-80. doi: 10.1002/art.37720. PubMed PMID: 23044660.

5. Zhao Z, Deocharan B, Scherer PE, Ozelius LJ, Putterman C. Differential binding of cross-reactive anti-DNA antibodies to mesangial cells: the role of alpha-actinin. J Immunol. 2006;176(12):7704-14. Epub 2006/06/06. doi: 176/12/7704 [pii]. PubMed PMID: 16751418.

6. Moritz CP, Tholance Y, Stoevesandt O, Ferraud K, Camdessanché JP, Antoine JC. CIDP Antibodies Target Junction Proteins and Identify Patient Subgroups: An Autoantigenomic Approach. Neurology(R) neuroimmunology \& neuroinflammation. 2021;8(2). Epub 2021/01/08. doi: 10.1212/nxi.0000000000000944. PubMed PMID: 33408168; PubMed Central PMCID: PMCPMC7862091.

7. Rucksaken R, Haonon O, Pinlaor P, Pairojkul C, Roytrakul S, Yongvanit $P$, et al. Plasma IgG autoantibody against actin-related protein 3 in liver fluke Opisthorchis viverrini infection. Parasite immunology. 2015;37(7):340-8. Epub 2015/03/27. doi: 10.1111/pim.12188. PubMed PMID: 25809205.

8. Wang T, Liu M, Zheng SJ, Bian DD, Zhang JY, Yao J, et al. Tumor-associated autoantibodies are useful biomarkers in immunodiagnosis of $\alpha$-fetoprotein-negative hepatocellular carcinoma. World J Gastroenterol. 2017;23(19):3496-504. Epub 2017/06/10. doi: 10.3748/wjg.v23.i19.3496. PubMed PMID: 28596685; PubMed Central PMCID: PMCPMC5442085.

9. Privitera D, Corti V, Alessio M, Volontè MA, Lampasona V, Comi G, et al. Proteomic identification of aldolase $A$ as an autoantibody target in patients with atypical movement disorders. Neurological sciences : official journal of the Italian Neurological Society and of the Italian Society of Clinical Neurophysiology. 2013;34(3):313-20. Epub 2012/03/07. doi: 10.1007/s10072-012-0996-y. PubMed PMID: 22391679.

10. Morohoshi K, Ohbayashi M, Patel N, Chong V, Bird AC, Ono SJ. Identification of anti-retinal antibodies in patients with age-related macular degeneration. Experimental and molecular pathology. 2012;93(2):193-9. Epub 2012/04/03. doi: 10.1016/j.yexmp.2012.03.007. PubMed PMID: 22465421.

11. Pott MC, Frede N, Wanders J, Hammarström L, Glocker EO, Glocker C, et al. Autoantibodies against BAFF, APRIL or IL21 - an alternative pathogenesis for antibody-deficiencies? BMC immunology. 2017;18(1):34. Epub 2017/06/28. doi: 10.1186/s12865-017-0217-9. PubMed PMID: 28651547; PubMed Central PMCID: PMCPMC5485583.

12. Hrycek A, Cieślik P. Annexin $A 5$ and anti-annexin antibodies in patients with systemic lupus erythematosus. Rheumatol Int. 2012;32(5):1335-42. Epub 2011/02/08. doi: 10.1007/s00296-011-1793-2. PubMed PMID: 21298269.

13. Seko Y, Matsumoto A, Fukuda T, Imai Y, Fujimura T, Taka H, et al. A case of neonatal lupus erythematosus presenting delayed dilated cardiomyopathy with circulating autoantibody to annexin A6. Int Heart J. 2007;48(3):407-15. PubMed PMID: 17592206.

14. Katsumata $Y$, Kawaguchi $Y$, Baba S, Hattori S, Tahara K, Ito K, et al. Identification of three new autoantibodies associated with systemic lupus erythematosus using two proteomic approaches. Molecular \& 
cellular proteomics : MCP. 2011;10(6):M110.005330. Epub 2011/04/09. doi: 10.1074/mcp.M110.005330. PubMed PMID: 21474795; PubMed Central PMCID: PMCPMC3108835.

15. Kamburova EG, Gruijters ML, Kardol-Hoefnagel T, Wisse BW, Joosten I, Allebes WA, et al. Antibodies against ARHGDIB are associated with long-term kidney graft loss. American journal of transplantation : official journal of the American Society of Transplantation and the American Society of Transplant Surgeons. 2019;19(12):3335-44. doi: 10.1111/ajt.15493. PubMed PMID: 31194283; PubMed Central PMCID: PMCPMC6899679.

16. Heo CK, Hwang HM, Lim WH, Lee HJ, Yoo JS, Lim KJ, et al. Cyclic Peptide Mimotopes for the Detection of Serum Anti-ATIC Autoantibody Biomarker in Hepato-Cellular Carcinoma. International journal of molecular sciences. 2020;21(24). Epub 2020/12/24. doi: 10.3390/ijms21249718. PubMed PMID: 33352757; PubMed Central PMCID: PMCPMC7766137.

17. Creaney J, Dick IM, Yeoman D, Wong S, Robinson BW. Auto-antibodies to $\beta$-F1-ATPase and vimentin in malignant mesothelioma. PloS one. 2011;6(10):e26515. Epub 2011/10/25. doi: 10.1371/journal.pone.0026515. PubMed PMID: 22022619; PubMed Central PMCID: PMCPMC3195718.

18. Beutgen VM, Schmelter C, Pfeiffer N, Grus FH. Autoantigens in the trabecular meshwork and glaucomaspecific alterations in the natural autoantibody repertoire. Clinical \& translational immunology. 2020;9(3):e01101. Epub 2020/03/07. doi: 10.1002/cti2.1101. PubMed PMID: 32140226; PubMed Central PMCID: PMCPMC7049230.

19. Gruber CN, Patel RS, Trachtman R, Lepow L, Amanat F, Krammer F, et al. Mapping Systemic Inflammation and Antibody Responses in Multisystem Inflammatory Syndrome in Children (MIS-C). Cell. 2020;183(4):98295.e14. Epub 2020/09/30. doi: 10.1016/j.cell.2020.09.034. PubMed PMID: 32991843; PubMed Central PMCID: PMCPMC7489877.

20. Boehm J, Orth T, Van Nguyen P, Soling HD. Systemic lupus erythematosus is associated with increased auto-antibody titers against calreticulin and grp94, but calreticulin is not the Ro/SS-A antigen. Eur J Clin Invest. 1994;24(4):248-57. Epub 1994/04/01. PubMed PMID: 8050453.

21. Matsuo K, Xiang Y, Nakamura H, Masuko K, Yudoh K, Noyori K, et al. Identification of novel citrullinated autoantigens of synovium in rheumatoid arthritis using a proteomic approach. Arthritis research \& therapy. 2006;8(6):R175. Epub 2006/11/28. doi: 10.1186/ar2085. PubMed PMID: 17125526; PubMed Central PMCID: PMCPMC1794520.

22. Li WH, Zhao J, Li HY, Liu H, Li AL, Wang HX, et al. Proteomics-based identification of autoantibodies in the sera of healthy Chinese individuals from Beijing. Proteomics. 2006;6(17):4781-9. Epub 2006/08/01. doi: 10.1002/pmic.200500909. PubMed PMID: 16878294.

23. Yokota SI, Hirata D, Minota S, Higashiyama T, Kurimoto M, Yanagi H, et al. Autoantibodies against chaperonin CCT in human sera with rheumatic autoimmune diseases: comparison with antibodies against other Hsp60 family proteins. Cell Stress Chaperones. 2000;5(4):337-46. Epub 2000/10/26. PubMed PMID: 11048656; PubMed Central PMCID: PMC312863.

24. Hirai K, Maeda H, Omori K, Yamamoto T, Kokeguchi S, Takashiba S. Serum antibody response to group II chaperonin from Methanobrevibacter oralis and human chaperonin CCT. Pathog Dis. 2013;68(1):12-9. Epub 2013/04/27. doi: 10.1111/2049-632x.12041. PubMed PMID: 23620386.

25. Goto M, Kuribayashi K, Takahashi Y, Kondoh T, Tanaka M, Kobayashi D, et al. Identification of autoantibodies expressed in acquired aplastic anaemia. British journal of haematology. 2013;160(3):359-62. Epub 2012/11/03. doi: 10.1111/bjh.12116. PubMed PMID: 23116149.

26. Rho JH, Zhang W, Murali M, Roehrl MH, Wang JY. Human proteins with affinity for dermatan sulfate have the propensity to become autoantigens. Am J Pathol. 2011;178(5):2177-90. doi: 10.1016/j.ajpath.2011.01.031. PubMed PMID: 21514432; PubMed Central PMCID: PMCPMC3081203.

27. Rouwette M, Noben JP, Van Horssen J, Van Wijmeersch B, Hupperts R, Jongen PJ, et al. Identification of coronin-1a as a novel antibody target for clinically isolated syndrome and multiple sclerosis. Journal of neurochemistry. 2013;126(4):483-92. doi: 10.1111/jnc.12335. PubMed PMID: 23745754. 
28. Bénistant $\mathrm{C}$, Bourgaux JF, Chapuis $\mathrm{H}$, Mottet $\mathrm{N}$, Roche S, Bali JP. The $\mathrm{COOH}$-terminal Src kinase Csk is a tumor antigen in human carcinoma. Cancer research. 2001;61(4):1415-20. Epub 2001/03/14. PubMed PMID: 11245444.

29. Schneider F, Aggarwal R, Bi D, Gibson K, Oddis C, Yousem SA. The pulmonary histopathology of anti-KS transfer RNA synthetase syndrome. Arch Pathol Lab Med. 2015;139(1):122-5. doi: 10.5858/arpa.2013-0667-OA. PubMed PMID: 25549148.

30. Netter HJ, Will H, Szostecki C, Guldner HH. Repetitive P68-autoantigen specific epitopes recognized by human anti-(U1) small nuclear ribonucleoprotein autoantibodies. Journal of autoimmunity. 1991;4(4):651-63. Epub 1991/08/01. doi: 10.1016/0896-8411(91)90183-d. PubMed PMID: 1723274.

31. Yamasaki Y, Narain S, Yoshida H, Hernandez L, Barker T, Hahn PC, et al. Autoantibodies to RNA helicase A: a new serologic marker of early lupus. Arthritis Rheum. 2007;56(2):596-604. doi: 10.1002/art.22329. PubMed PMID: 17265494.

32. Yoneyama K, Shibata R, Igarashi A, Kojima S, Kodani Y, Nagata K, et al. Proteomic identification of dihydrolipoamide dehydrogenase as a target of autoantibodies in patients with endometrial cancer. Anticancer research. 2014;34(9):5021-7. Epub 2014/09/10. PubMed PMID: 25202086.

33. Kim EG, Kwak SH, Hwang D, Yi EC, Park KS, Koo BK, et al. The Level of Autoantibodies Targeting Eukaryote Translation Elongation Factor $1 \alpha 1$ and Ubiquitin-Conjugating Enzyme 2 L3 in Nondiabetic Young Adults. Diabetes Metab J. 2016;40(2):154-60. Epub 2015/12/01. doi: 10.4093/dmj.2016.40.2.154. PubMed PMID: 26616590; PubMed Central PMCID: PMCPMC4853223.

34. Mooney CJ, Dunphy EJ, Stone B, McNeel DG. Identification of autoantibodies elicited in a patient with prostate cancer presenting as dermatomyositis. Int J Urol. 2006;13(3):211-7. doi: 10.1111/j.14422042.2006.01263.x. PubMed PMID: 16643611.

35. Ohkouchi K, Mizutani H, Tanaka M, Takahashi M, Nakashima K, Shimizu M. Anti-elongation factor-1alpha autoantibody in adult atopic dermatitis patients. Int Immunol. 1999;11(10):1635-40. Epub 1999/10/03. PubMed PMID: 10508181.

36. Fernández-Madrid F, Tang N, Alansari H, Granda JL, Tait L, Amirikia KC, et al. Autoantibodies to Annexin $\mathrm{XI-A}$ and Other Autoantigens in the Diagnosis of Breast Cancer. Cancer research. 2004;64(15):5089-96. Epub 2004/08/04. doi: 10.1158/0008-5472.can-03-0932. PubMed PMID: 15289310.

37. Bach $M$, Winkelmann $G$, Luhrmann R. 20S small nuclear ribonucleoprotein U5 shows a surprisingly complex protein composition. Proceedings of the National Academy of Sciences of the United States of America. 1989;86(16):6038-42. doi: 10.1073/pnas.86.16.6038. PubMed PMID: 2527369; PubMed Central PMCID: PMCPMC297770.

38. Heo CK, Hwang HM, Lee HJ, Kwak SS, Yoo JS, Yu DY, et al. Serum anti-EIF3A autoantibody as a potential diagnostic marker for hepatocellular carcinoma. Sci Rep. 2019;9(1):11059. doi: 10.1038/s41598-019-47365-4. PubMed PMID: 31363116; PubMed Central PMCID: PMCPMC6667438.

39. Chen X, Fu S, Chen F, Chen H, Chen Z. Identification of tumor-associated antigens in human hepatocellular carcinoma by autoantibodies. Oncol Rep. 2008;20(4):979-85. Epub 2008/09/25. PubMed PMID: 18813843.

40. Betteridge $Z$, Chinoy $H$, Vencovsky J, Winer J, Putchakayala K, Ho P, et al. Identification of a novel autoantigen eukaryotic initiation factor 3 associated with polymyositis. Rheumatology (Oxford, England). 2020;59(5):1026-30. Epub 2019/11/16. doi: 10.1093/rheumatology/kez406. PubMed PMID: 31728542; PubMed Central PMCID: PMCPMC7188460.

41. Suwarnalata G, Tan AH, Isa H, Gudimella R, Anwar A, Loke MF, et al. Augmentation of Autoantibodies by Helicobacter pylori in Parkinson's Disease Patients May Be Linked to Greater Severity. PloS one. 2016;11(4):e0153725. Epub 2016/04/23. doi: 10.1371/journal.pone.0153725. PubMed PMID: 27100827; PubMed Central PMCID: PMCPMC4839651 academic editor of PLOS ONE. The rest of the authors declare that they have no conflict of interest. This does not alter the authors' adherence to PLOS ONE policies on sharing data and materials. 
42. Pagaza-Straffon C, Marchat LA, Herrera L, Díaz-Chávez J, Avante MG, Rodríguez YP, et al. Evaluation of a panel of tumor-associated antigens in breast cancer. Cancer biomarkers : section A of Disease markers. 2020;27(2):207-11. Epub 2019/12/17. doi: 10.3233/cbm-190708. PubMed PMID: 31839604.

43. Nabors LB, Furneaux HM, King PH. HuR, a novel target of anti-Hu antibodies, is expressed in non-neural tissues. Journal of neuroimmunology. 1998;92(1-2):152-9. PubMed PMID: 9916890.

44. O'Dwyer DT, Clifton V, Hall A, Smith R, Robinson PJ, Crock PA. Pituitary autoantibodies in lymphocytic hypophysitis target both gamma- and alpha-Enolase - a link with pregnancy? Archives of physiology and biochemistry. 2002;110(1-2):94-8. Epub 2002/04/06. doi: 10.1076/apab.110.1.94.897. PubMed PMID: 11935405.

45. Targoff IN, Trieu EP, Miller FW. Reaction of anti-OJ autoantibodies with components of the multi-enzyme complex of aminoacyl-tRNA synthetases in addition to isoleucyl-tRNA synthetase. The Journal of clinical investigation. 1993;91(6):2556-64. doi: 10.1172/JCI116493. PubMed PMID: 8514867; PubMed Central PMCID: PMCPMC443318.

46. Capello M, Cappello P, Linty FC, Chiarle R, Sperduti I, Novarino A, et al. Autoantibodies to Ezrin are an early sign of pancreatic cancer in humans and in genetically engineered mouse models. Journal of hematology \& oncology. 2013;6:67. Epub 2013/09/10. doi: 10.1186/1756-8722-6-67. PubMed PMID: 24010981; PubMed Central PMCID: PMCPMC3844582.

47. Betteridge Z, Gunawardena H, North J, Slinn J, McHugh N. Anti-synthetase syndrome: a new autoantibody to phenylalanyl transfer RNA synthetase (anti-Zo) associated with polymyositis and interstitial pneumonia. Rheumatology (Oxford, England). 2007;46(6):1005-8. doi: 10.1093/rheumatology/kem045. PubMed PMID: 17392287.

48. Heo CK, Woo MK, Yu DY, Lee JY, Yoo JS, Yoo HS, et al. Identification of autoantibody against fatty acid synthase in hepatocellular carcinoma mouse model and its application to diagnosis of HCC. Int J Oncol. 2010;36(6):1453-9. Epub 2010/04/30. doi: 10.3892/ijo_00000631. PubMed PMID: 20428769.

49. Desmetz C, Bascoul-Mollevi C, Rochaix P, Lamy PJ, Kramar A, Rouanet P, et al. Identification of a new panel of serum autoantibodies associated with the presence of in situ carcinoma of the breast in younger women. Clinical cancer research : an official journal of the American Association for Cancer Research. 2009;15(14):4733-41. Epub 2009/07/09. doi: 10.1158/1078-0432.ccr-08-3307. PubMed PMID: 19584157.

50. Terrier B, Tamby MC, Camoin L, Guilpain P, Broussard C, Bussone G, et al. Identification of target antigens of antifibroblast antibodies in pulmonary arterial hypertension. American journal of respiratory and critical care medicine. 2008;177(10):1128-34. Epub 2008/02/16. doi: 10.1164/rccm.200707-10150C. PubMed PMID: 18276943.

51. Kit Y, Starykovych M, Vajrychova M, Lenco J, Zastavna D, Stoika R. Detection of novel auto-antigens in patients with recurrent miscarriage: description of an approach and preliminary findings. Croat Med J. 2014;55(3):259-64. PubMed PMID: 24891284; PubMed Central PMCID: PMCPMC4049207.

52. Takasaki Y, Kaneda K, Matsushita M, Yamada H, Nawata M, Matsudaira R, et al. Glyceraldehyde 3phosphate dehydrogenase is a novel autoantigen leading autoimmune responses to proliferating cell nuclear antigen multiprotein complexes in lupus patients. Int Immunol. 2004;16(9):1295-304. Epub 2004/07/21. doi: 10.1093/intimm/dxh131 [doi]

dxh131 [pii]. PubMed PMID: 15262899.

53. Schneider F, Yousem SA, Bi D, Gibson KF, Oddis CV, Aggarwal R. Pulmonary pathologic manifestations of anti-glycyl-tRNA synthetase (anti-EJ)-related inflammatory myopathy. Journal of clinical pathology. 2014;67(8):678-83. Epub 2014/06/04. doi: 10.1136/jclinpath-2014-202367. PubMed PMID: 24891607.

54. Kiyota A, Iwama S, Sugimura $Y$, Takeuchi S, Takagi $H$, Iwata N, et al. Identification of the novel autoantigen candidate Rab GDP dissociation inhibitor alpha in isolated adrenocorticotropin deficiency. Endocrine journal. 2015;62(2):153-60. Epub 2014/10/28. doi: 10.1507/endocrj.EJ14-0369. PubMed PMID: 25346144.

55. Massa O, Alessio M, Russo L, Nardo G, Bonetto V, Bertuzzi F, et al. Serological Proteome Analysis (SERPA) as a tool for the identification of new candidate autoantigens in type 1 diabetes. Journal of proteomics. 2013;82:263-73. Epub 2013/03/19. doi: 10.1016/j.jprot.2013.02.030. PubMed PMID: 23500132. 
56. Carlsson L, Ronquist G, Nilsson BO, Larsson A. Dominant prostasome immunogens for spermagglutinating autoantibodies of infertile men. Journal of andrology. 2004;25(5):699-705. Epub 2004/08/05. doi: 10.1002/j.1939-4640.2004.tb02844.x. PubMed PMID: 15292099.

57. Belousov PV, Afanasyeva MA, Gubernatorova EO, Bogolyubova AV, Uvarova AN, Putlyaeva LV, et al. Multi-dimensional immunoproteomics coupled with in vitro recapitulation of oncogenic NRAS(Q61R) identifies diagnostically relevant autoantibody biomarkers in thyroid neoplasia. Cancer letters. 2019;467:96-106. Epub 2019/07/22. doi: 10.1016/j.canlet.2019.07.013. PubMed PMID: 31326556.

58. Rubin RL, Bell SA, Burlingame RW. Autoantibodies associated with lupus induced by diverse drugs target a similar epitope in the (H2A-H2B)-DNA complex. The Journal of clinical investigation. 1992;90(1):165-73. doi: 10.1172/JCI115832. PubMed PMID: 1378852; PubMed Central PMCID: PMCPMC443077.

59. Burlingame RW, Boey ML, Starkebaum G, Rubin RL. The central role of chromatin in autoimmune responses to histones and DNA in systemic lupus erythematosus. The Journal of clinical investigation. 1994;94(1):184-92. doi: 10.1172/JCI117305. PubMed PMID: 8040259; PubMed Central PMCID: PMCPMC296296.

60. Rosenberg AM, Cordeiro DM. Relationship between sex and antibodies to high mobility group proteins 1 and 2 in juvenile idiopathic arthritis. J Rheumatol. 2000;27(10):2489-93. Epub 2000/10/19. PubMed PMID: 11036848.

61. Wesierska-Gadek J, Penner E, Lindner H, Hitchman E, Sauermann G. Autoantibodies against different histone H1 subtypes in systemic lupus erythematosus sera. Arthritis and rheumatism. 1990;33(8):1273-8. PubMed PMID: 2390129.

62. Vordenbaumen S, Bohmer P, Brinks R, Fischer-Betz R, Richter J, Bleck E, et al. High diagnostic accuracy of histone H4-lgG autoantibodies in systemic lupus erythematosus. Rheumatology (Oxford, England). 2018;57(3):533-7. doi: 10.1093/rheumatology/kex462. PubMed PMID: 29267954.

63. Baranova SV, Dmitrienok PS, Ivanisenko NV, Buneva VN, Nevinsky GA. Antibodies to H2a and H2b histones from the sera of HIV-infected patients catalyze site-specific degradation of these histones. Molecular bioSystems. 2017;13(6):1090-101. Epub 2017/04/21. doi: 10.1039/c7mb00042a. PubMed PMID: 28426042.

64. Bruschi M, Galetti M, Sinico RA, Moroni G, Bonanni A, Radice A, et al. Glomerular Autoimmune Multicomponents of Human Lupus Nephritis In Vivo (2): Planted Antigens. Journal of the American Society of Nephrology : JASN. 2015;26(8):1905-24. doi: 10.1681/ASN.2014050493. PubMed PMID: 25398787; PubMed Central PMCID: PMCPMC4520170.

65. van Bavel CC, Dieker J, Muller S, Briand JP, Monestier M, Berden JH, et al. Apoptosis-associated acetylation on histone H2B is an epitope for lupus autoantibodies. Molecular immunology. 2009;47(2-3):511-6. Epub 2009/09/15. doi: S0161-5890(09)00686-5 [pii]

10.1016/j.molimm.2009.08.009. PubMed PMID: 19747733.

66. Baranova SV, Dmitrenok PS, Zubkova AD, Ivanisenko NV, Odintsova ES, Buneva VN, et al. Antibodies against $\mathrm{H} 3$ and $\mathrm{H} 4$ histones from the sera of HIV-infected patients catalyze site-specific degradation of these histones. Journal of molecular recognition : JMR. 2018;31(7):e2703. Epub 2018/02/20. doi: 10.1002/jmr.2703. PubMed PMID: 29457292.

67. Astaldi Ricotti GC, Bestagno M, Cerino A, Negri C, Caporali R, Cobianchi F, et al. Antibodies to hnRNP core protein A1 in connective tissue diseases. J Cell Biochem. 1989;40(1):43-7. Epub 1989/05/01. doi: 10.1002/jcb.240400105 [doi]. PubMed PMID: 2745573.

68. Konig MF, Giles JT, Nigrovic PA, Andrade F. Antibodies to native and citrullinated RA33 (hnRNP A2/B1) challenge citrullination as the inciting principle underlying loss of tolerance in rheumatoid arthritis. Annals of the rheumatic diseases. 2016;75(11):2022-8. doi: 10.1136/annrheumdis-2015-208529. PubMed PMID: 26865600.

69. Siapka S, Patrinou-Georgoula M, Vlachoyiannopoulos PG, Guialis A. Multiple specificities of autoantibodies against hnRNP A/B proteins in systemic rheumatic diseases and hnRNP $L$ as an associated novel autoantigen. Autoimmunity. 2007;40(3):223-33. doi: 10.1080/08916930701352357. PubMed PMID: 17453722. 70. Stanek D, Vencovsky J, Kafkova J, Raska I. Heterogenous nuclear RNP C1 and C2 core proteins are targets for an autoantibody found in the serum of a patient with systemic sclerosis and psoriatic arthritis. Arthritis and 
rheumatism. 1997;40(12):2172-7. doi: 10.1002/1529-0131(199712)40:12\&lt;2172::AID-ART10\&gt;3.0.CO;2-V. PubMed PMID: 9416854.

71. Skriner K, Hueber W, Süleymanoglu E, Höfler E, Krenn V, Smolen J, et al. AUF1, the regulator of tumor necrosis factor alpha messenger RNA decay, is targeted by autoantibodies of patients with systemic rheumatic diseases. Arthritis and rheumatism. 2008;58(2):511-20. Epub 2008/02/02. doi: 10.1002/art.23306. PubMed PMID: 18240226.

72. Zhang Y, Zhao H, Liu B, Li L, Zhang L, Bao M, et al. Low Level Antibodies Against Alpha-Tropomyosin Are Associated With Increased Risk of Coronary Heart Disease. Frontiers in pharmacology. 2020;11:195. Epub 2020/03/17. doi: 10.3389/fphar.2020.00195. PubMed PMID: 32174839; PubMed Central PMCID: PMCPMC7056748.

73. Op De Beéck K, Maes L, Van den Bergh K, Derua R, Waelkens E, Van Steen K, et al. Heterogeneous nuclear RNPs as targets of autoantibodies in systemic rheumatic diseases. Arthritis and rheumatism. 2012;64(1):213-21. Epub 2011/09/10. doi: 10.1002/art.33327. PubMed PMID: 21905010.

74. Rauch J, Ahlemann M, Schaffrik M, Mack B, Ertongur S, Andratschke M, et al. Allogenic antibodymediated identification of head and neck cancer antigens. Biochem Biophys Res Commun. 2004;323(1):156-62. Epub 2004/09/08. doi: 10.1016/j.bbrc.2004.08.071 [doi] S0006-291X(04)01792-9 [pii]. PubMed PMID: 15351715.

75. Zhang JY, Chan EK, Peng XX, Tan EM. A novel cytoplasmic protein with RNA-binding motifs is an autoantigen in human hepatocellular carcinoma. J Exp Med. 1999;189(7):1101-10. Epub 1999/04/06. PubMed PMID: 10190901; PubMed Central PMCID: PMC2193003.

76. Hassfeld W, Chan EK, Mathison DA, Portman D, Dreyfuss G, Steiner G, et al. Molecular definition of heterogeneous nuclear ribonucleoprotein $\mathrm{R}$ (hnRNP R) using autoimmune antibody: immunological relationship with hnRNP P. Nucleic Acids Res. 1998;26(2):439-45. PubMed PMID: 9421497; PubMed Central PMCID: PMCPMC147279.

77. Britton S, Froment C, Frit P, Monsarrat B, Salles B, Calsou P. Cell nonhomologous end joining capacity controls SAF-A phosphorylation by DNA-PK in response to DNA double-strand breaks inducers. Cell Cycle. 2009;8(22):3717-22. Epub 2009/10/22. doi: 10025 [pii]. PubMed PMID: 19844162.

78. Harlow L, Rosas IO, Gochuico BR, Mikuls TR, Dellaripa PF, Oddis CV, et al. Identification of citrullinated hsp90 isoforms as novel autoantigens in rheumatoid arthritis-associated interstitial lung disease. Arthritis and rheumatism. 2013;65(4):869-79. doi: 10.1002/art.37881. PubMed PMID: 23400887.

79. Qin HY, Mahon JL, Atkinson MA, Chaturvedi P, Lee-Chan E, Singh B. Type 1 diabetes alters anti-hsp90 autoantibody isotype. Journal of autoimmunity. 2003;20(3):237-45. Epub 2003/05/20. doi: 10.1016/s08968411(03)00035-0. PubMed PMID: 12753809.

80. Pashov A, Kenderov A, Kyurkchiev S, Kehayov I, Hristova S, Lacroix-Desmazes S, et al. Autoantibodies to heat shock protein 90 in the human natural antibody repertoire. Int Immunol. 2002;14(5):453-61. PubMed PMID: 11978775.

81. Tishler $M$, Shoenfeld $\mathrm{Y}$. Anti-heat-shock protein antibodies in rheumatic and autoimmune diseases. Semin Arthritis Rheum. 1996;26(2):558-63. PubMed PMID: 8916299.

82. Blass S, Union A, Raymackers J, Schumann F, Ungethum U, Muller-Steinbach S, et al. The stress protein $\mathrm{BiP}$ is overexpressed and is a major B and T cell target in rheumatoid arthritis. Arthritis Rheum. 2001;44(4):76171. Epub 2001/04/24. doi: 10.1002/1529-0131(200104)44:4<761::AID-ANR132>3.0.CO;2-S [doi]. PubMed PMID: 11315915.

83. Munakata S, Chen M, Aosai F, Kawaguchi N, Nemoto Y, Norose K, et al. The clinical significance of antiheat shock cognate protein 71 antibody in myasthenia gravis. J Clin Neurosci. 2008;15(2):158-65. Epub 2007/11/06. doi: S0967-5868(06)00433-4 [pii]

10.1016/j.jocn.2006.07.006. PubMed PMID: 17981040.

84. Alard JE, Dueymes M, Mageed RA, Saraux A, Youinou P, Jamin C. Mitochondrial heat shock protein (HSP) 70 synergizes with HSP60 in transducing endothelial cell apoptosis induced by anti-HSP60 autoantibody. Faseb J. 2009;23(8):2772-9. PubMed PMID: 19346294. 
85. Horvath L, Cervenak L, Oroszlan M, Prohaszka Z, Uray K, Hudecz F, et al. Antibodies against different epitopes of heat-shock protein 60 in children with type 1 diabetes mellitus. Immunol Lett. 2002;80(3):155-62. Epub 2002/01/23. doi: S0165247801003364 [pii]. PubMed PMID: 11803047.

86. Minohara M. [Heat shock protein 105 in multiple sclerosis]. Nippon Rinsho. 2003;61(8):1317-22. Epub 2003/09/10. PubMed PMID: 12962017.

87. Bremer HD, Landegren N, Sjoberg R, Hallgren A, Renneker S, Lattwein E, et al. ILF2 and ILF3 are autoantigens in canine systemic autoimmune disease. Sci Rep. 2018;8(1):4852. doi: 10.1038/s41598-018-23034w. PubMed PMID: 29556082; PubMed Central PMCID: PMCPMC5859008.

88. Ola TO, Biro PA, Hawa MI, Ludvigsson J, Locatelli M, Puglisi MA, et al. Importin beta: a novel autoantigen in human autoimmunity identified by screening random peptide libraries on phage. Journal of autoimmunity. 2006;26(3):197-207. doi: 10.1016/j.jaut.2006.01.003. PubMed PMID: 16549322.

89. Luo LY, Herrera I, Soosaipillai A, Diamandis EP. Identification of heat shock protein 90 and other proteins as tumour antigens by serological screening of an ovarian carcinoma expression library. British journal of cancer. 2002;87(3):339-43. Epub 2002/08/15. doi: 10.1038/sj.bjc.6600439. PubMed PMID: 12177805; PubMed Central PMCID: PMCPMC2364218.

90. Presslauer S, Hinterhuber G, Cauza K, Horvat R, Rappersberger K, Wolff K, et al. RasGAP-like protein IQGAP1 is expressed by human keratinocytes and recognized by autoantibodies in association with bullous skin disease. The Journal of investigative dermatology. 2003;120(3):365-71. doi: 10.1046/j.1523-1747.2003.12070.x. PubMed PMID: 12603848.

91. Ueda K, Nakanishi T, Shimizu A, Takubo T, Matsuura N. Identification of L-plastin autoantibody in plasma of patients with non-Hodgkin's lymphoma using a proteomics-based analysis. Ann Clin Biochem. 2008;45(Pt 1):65-9. Epub 2008/02/16. doi: 10.1258/acb.2007.006230. PubMed PMID: 18275676.

92. Forti S, Scanlan MJ, Invernizzi A, Castiglioni F, Pupa S, Agresti R, et al. Identification of breast cancerrestricted antigens by antibody screening of SKBR3 cDNA library using a preselected patient's serum. Breast cancer research and treatment. 2002;73(3):245-56. Epub 2002/08/06. doi: 10.1023/a:1015854415746. PubMed PMID: 12160330.

93. Gemma R, Suzuki Y, Tanaka I, Taminato T, Yoshimi T, Kanno T. Lactate dehydrogenase (LDH)-linked immunoglobulin in a patient with Graves' disease treated with methimazole. Intern Med. 1992;31(3):377-9. Epub 1992/03/01. PubMed PMID: 1611190.

94. Tanaka M, Kishimura M, Ozaki S, Osakada F, Hashimoto H, Okubo M, et al. Cloning of novel soluble gp130 and detection of its neutralizing autoantibodies in rheumatoid arthritis. The Journal of clinical investigation. 2000;106(1):137-44. doi: 10.1172/JCI7479. PubMed PMID: 10880057; PubMed Central PMCID: PMCPMC314355.

95. Frampton G, Moriya S, Pearson JD, Isenberg DA, Ward FJ, Smith TA, et al. Identification of candidate endothelial cell autoantigens in systemic lupus erythematosus using a molecular cloning strategy: a role for ribosomal P protein P0 as an endothelial cell autoantigen. Rheumatology (Oxford, England). 2000;39(10):111420. Epub 2000/10/18. doi: 10.1093/rheumatology/39.10.1114. PubMed PMID: 11035132.

96. Suzuki K, Nagao T, Itabashi M, Hamano Y, Sugamata R, Yamazaki Y, et al. A novel autoantibody against moesin in the serum of patients with MPO-ANCA-associated vasculitis. Nephrol Dial Transplant. 2014;29(6):1168-77. doi: 10.1093/ndt/gft469. PubMed PMID: 24319012.

97. Mossabeb R, Seiberler S, Mittermann I, Reininger R, Spitzauer S, Natter S, et al. Characterization of a novel isoform of alpha-nascent polypeptide-associated complex as IgE-defined autoantigen. The Journal of investigative dermatology. 2002;119(4):820-9. Epub 2002/10/31. doi: 10.1046/j.1523-1747.2002.00518.x. PubMed PMID: 12406326.

98. Beaulande $\mathrm{M}$, Kron M, Hirakata M, Härtlein M. Human anti-asparaginyl-tRNA synthetase autoantibodies (anti-KS) increase the affinity of the enzyme for its tRNA substrate. FEBS letters. 2001;494(3):170-4. Epub 2001/04/20. doi: 10.1016/s0014-5793(01)02340-7. PubMed PMID: 11311235.

99. Batova IN, Richardson RT, Widgren EE, O'Rand MG. Analysis of the autoimmune epitopes on human testicular NASP using recombinant and synthetic peptides. Clinical and experimental immunology. 
2000;121(2):201-9. Epub 2000/08/10. doi: 10.1046/j.1365-2249.2000.01303.x. PubMed PMID: 10931132; PubMed Central PMCID: PMCPMC1905703.

100. Qin Z, Lavingia B, Zou Y, Stastny P. Antibodies against nucleolin in recipients of organ transplants. Transplantation. 2011;92(7):829-35. doi: 10.1097/TP.0b013e31822d0977. PubMed PMID: 21869741.

101. Le Naour F, Brichory F, Misek DE, Brechot C, Hanash SM, Beretta L. A distinct repertoire of autoantibodies in hepatocellular carcinoma identified by proteomic analysis. Molecular \& cellular proteomics : MCP. 2002;1(3):197-203. PubMed PMID: 12096119.

102. Ulanet DB, Torbenson M, Dang CV, Casciola-Rosen L, Rosen A. Unique conformation of cancer autoantigen B23 in hepatoma: a mechanism for specificity in the autoimmune response. Proc Natl Acad Sci U S A. 2003;100(21):12361-6. Epub 2003/10/02. doi: 10.1073/pnas.2035245100 [doi] 2035245100 [pii]. PubMed PMID: 14519847; PubMed Central PMCID: PMC218763.

103. Nagayama S, Yokoi T, Tanaka H, Kawaguchi Y, Shirasaka T, Kamataki T. Occurrence of autoantibody to protein disulfide isomerase in patients with hepatic disorder. J Toxicol Sci. 1994;19(3):163-9. PubMed PMID: 7966454.

104. Becker A, Ludwig N, Keller A, Tackenberg B, Eienbroker C, Oertel WH, et al. Myasthenia gravis: analysis of serum autoantibody reactivities to 1827 potential human autoantigens by protein macroarrays. PloS one. 2013;8(3):e58095. doi: 10.1371/journal.pone.0058095. PubMed PMID: 23483977; PubMed Central PMCID: PMCPMC3587426.

105. Caorsi C, Niccolai E, Capello M, Vallone R, Chattaragada MS, Alushi B, et al. Protein disulfide isomerase A3-specific Th1 effector cells infiltrate colon cancer tissue of patients with circulating anti-protein disulfide isomerase A3 autoantibodies. Transl Res. 2016;171:17-28.e1-2. Epub 2016/01/17. doi: 10.1016/j.trsl.2015.12.013. PubMed PMID: 26772958.

106. Gut J, Christen U, Frey N, Koch V, Stoffler D. Molecular mimicry in halothane hepatitis: biochemical and structural characterization of lipoylated autoantigens. Toxicology. 1995;97(1-3):199-224. Epub 1995/03/31. PubMed PMID: 7716787.

107. Chang DC, Piaggi P, Hanson RL, Knowler WC, Bogardus C, Krakoff J. Autoantibodies against PFDN2 are associated with an increased risk of type 2 diabetes: A case-control study. Diabetes Metab Res Rev. 2017;33(8). doi: 10.1002/dmrr.2922. PubMed PMID: 28731290; PubMed Central PMCID: PMCPMC6417877.

108. Kimura A, Sakurai T, Koumura A, Yamada M, Hayashi Y, Tanaka Y, et al. High prevalence of autoantibodies against phosphoglycerate mutase 1 in patients with autoimmune central nervous system diseases. Journal of neuroimmunology. 2010;219(1-2):105-8. Epub 2009/12/09. doi: 10.1016/j.jneuroim.2009.11.014. PubMed PMID: 19969379.

109. Xiang D, Xia Q, Chen D, Feng X, Zhao Y, Liu Y, et al. Detection of D-3-phosphoglycerate dehydrogenase autoantibodies in patients with autoimmune hepatitis: Clinical significance evaluation. Hepatology research : the official journal of the Japan Society of Hepatology. 2011;41(9):867-76. Epub 2011/06/29. doi: 10.1111/j.1872034X.2011.00839.x. PubMed PMID: 21707887.

110. Loshaj-Shala A, Colzani M, Brezovska K, Poceva Panovska A, Suturkova L, Beretta G. Immunoproteomic identification of antigenic candidate Campylobacter jejuni and human peripheral nerve proteins involved in Guillain-Barré syndrome. Journal of neuroimmunology. 2018;317:77-83. Epub 2018/01/18. doi: 10.1016/j.jneuroim.2018.01.006. PubMed PMID: 29338928.

111. Kratz A, Harding MW, Craft J, Mackworth-Young CG, Handschumacher RE. Autoantibodies against cyclophilin in systemic lupus erythematosus and Lyme disease. Clinical and experimental immunology. 1992;90(3):422-7. PubMed PMID: 1458678; PubMed Central PMCID: PMCPMC1554566.

112. Karasawa R, Ozaki S, Nishioka K, Kato T. Autoantibodies to peroxiredoxin I and IV in patients with systemic autoimmune diseases. Microbiology and immunology. 2005;49(1):57-65. Epub 2005/01/25. doi: 10.1111/j.1348-0421.2005.tb03640.x. PubMed PMID: 15665454.

113. Lin LH, Xu YW, Huang LS, Hong CQ, Zhai TT, Liao LD, et al. Serum proteomic-based analysis identifying autoantibodies against PRDX2 and PRDX3 as potential diagnostic biomarkers in nasopharyngeal carcinoma. Clinical proteomics. 2017;14:6. Epub 2017/02/12. doi: 10.1186/s12014-017-9141-5. PubMed PMID: 28184180; PubMed Central PMCID: PMCPMC5289059. 
114. Sun KH, Tang SJ, Wang YS, Lin WJ, You RI. Autoantibodies to dsDNA cross-react with the arginine-glycinerich domain of heterogeneous nuclear ribonucleoprotein A2 (hnRNP A2) and promote methylation of hnRNP A2. Rheumatology (Oxford). 2003;42(1):154-61. Epub 2003/01/02. PubMed PMID: 12509629.

115. Mayo I, Arribas J, Villoslada P, Alvarez DoForno R, Rodriguez-Vilarino S, Montalban X, et al. The proteasome is a major autoantigen in multiple sclerosis. Brain. 2002;125(Pt 12):2658-67. doi: 10.1093/brain/awf274. PubMed PMID: 12429593.

116. Feist E, Kuckelkorn U, Dörner T, Dönitz H, Scheffler S, Hiepe F, et al. Autoantibodies in primary Sjögren's syndrome are directed against proteasomal subunits of the alpha and beta type. Arthritis and rheumatism. 1999;42(4):697-702. Epub 1999/04/22. doi: 10.1002/1529-0131(199904)42:4<697::aid-anr12>3.0.co;2-h. PubMed PMID: 10211883.

117. Feist E, Dorner T, Kuckelkorn U, Schmidtke G, Micheel B, Hiepe F, et al. Proteasome alpha-type subunit C9 is a primary target of autoantibodies in sera of patients with myositis and systemic lupus erythematosus. The Journal of experimental medicine. 1996;184(4):1313-8. PubMed PMID: 8879203; PubMed Central PMCID: PMCPMC2192827.

118. Bohring C, Krause W. Characterization of spermatozoa surface antigens by antisperm antibodies and its influence on acrosomal exocytosis. Am J Reprod Immunol. 2003;50(5):411-9. PubMed PMID: 14750700.

119. Sugimoto K, Hiwasa T, Shibuya K, Hirano S, Beppu M, Isose S, et al. Novel autoantibodies against the proteasome subunit PSMA7 in amyotrophic lateral sclerosis. Journal of neuroimmunology. 2018;325:54-60. doi: 10.1016/j.jneuroim.2018.09.013. PubMed PMID: 30390597.

120. Scheffler S, Kuckelkorn U, Egerer K, Dörner T, Reiter K, Soza A, et al. Autoimmune reactivity against the 20S-proteasome includes immunosubunits LMP2 (beta1i), MECL1 (beta2i) and LMP7 (beta5i). Rheumatology (Oxford, England). 2008;47(5):622-6. Epub 2008/04/01. doi: 10.1093/rheumatology/ken042. PubMed PMID: 18375405.

121. Luna Coronell JA, Sergelen K, Hofer P, Gyurján I, Brezina S, Hettegger P, et al. The Immunome of Colon Cancer: Functional In Silico Analysis of Antigenic Proteins Deduced from IgG Microarray Profiling. Genomics, proteomics \& bioinformatics. 2018;16(1):73-84. Epub 2018/03/06. doi: 10.1016/j.gpb.2017.10.002. PubMed PMID: 29505855; PubMed Central PMCID: PMCPMC6000238.

122. Roessler $M$, Rollinger $W$, Mantovani-Endl L, Hagmann ML, Palme S, Berndt $P$, et al. Identification of PSME3 as a novel serum tumor marker for colorectal cancer by combining two-dimensional polyacrylamide gel electrophoresis with a strictly mass spectrometry-based approach for data analysis. Mol Cell Proteomics. 2006;5(11):2092-101. Epub 2006/08/09. doi: M600118-MCP200 [pii]

10.1074/mcp.M600118-MCP200. PubMed PMID: 16893879.

123. Montecucco C, Caporali R, Cobianchi F, Biamonti G. Identification of autoantibodies to the I protein of the heterogeneous nuclear ribonucleoprotein complex in patients with systemic sclerosis. Arthritis and rheumatism. 1996;39(10):1669-76. Epub 1996/10/01. doi: 10.1002/art.1780391009. PubMed PMID: 8843857.

124. Thébault S, Gilbert D, Hubert M, Drouot L, Machour N, Lange C, et al. Orderly pattern of development of the autoantibody response in (New Zealand White x BXSB)F1 lupus mice: characterization of target antigens and antigen spreading by two-dimensional gel electrophoresis and mass spectrometry. Journal of immunology (Baltimore, Md : 1950). 2002;169(7):4046-53. Epub 2002/09/24. doi: 10.4049/jimmunol.169.7.4046. PubMed PMID: 12244208.

125. Wagatsuma M, Kimura M, Suzuki R, Takeuchi F, Matsuta K, Watanabe H. Ezrin, radixin and moesin are possible auto-immune antigens in rheumatoid arthritis. Molecular immunology. 1996;33(15):1171-6. Epub 1996/10/01. doi: 10.1016/s0161-5890(96)00083-1. PubMed PMID: 9070665.

126. Gerli R, Caponi L. Anti-ribosomal P protein antibodies. Autoimmunity. 2005;38(1):85-92. Epub 2005/04/05. doi: N1M7262UW316830N [pii]

10.1080/08916930400022699 [doi]. PubMed PMID: 15804709.

127. Tycowski KT, Shu MD, Steitz JA. A small nucleolar RNA is processed from an intron of the human gene encoding ribosomal protein S3. Genes \& development. 1993;7(7a):1176-90. Epub 1993/07/01. doi: 10.1101/gad.7.7a.1176. PubMed PMID: 8319909. 
128. Kaji K, Fertig N, Medsger TA, Jr., Satoh T, Hoshino K, Hamaguchi Y, et al. Autoantibodies to RuvBL1 and RuvBL2: a novel systemic sclerosis-related antibody associated with diffuse cutaneous and skeletal muscle involvement. Arthritis care \& research. 2014;66(4):575-84. Epub 2013/09/12. doi: 10.1002/acr.22163. PubMed PMID: 24023044.

129. Pauling JD, Salazar G, Lu H, Betteridge ZE, Assassi S, Mayes MD, et al. Presence of anti-eukaryotic initiation factor-2B, anti-RuvBL1/2 and anti-synthetase antibodies in patients with anti-nuclear antibody negative systemic sclerosis. Rheumatology (Oxford, England). 2018;57(4):712-7. doi: 10.1093/rheumatology/kex458. PubMed PMID: 29294089.

130. Margutti P, Sorice M, Conti F, Delunardo F, Racaniello M, Alessandri C, et al. Screening of an endothelial cDNA library identifies the C-terminal region of Nedd 5 as a novel autoantigen in systemic lupus erythematosus with psychiatric manifestations. Arthritis research \& therapy. 2005;7(4):R896-903. Epub 2005/07/01. doi: 10.1186/ar1759. PubMed PMID: 15987492; PubMed Central PMCID: PMCPMC1175040.

131. Lefranc D, Launay D, Dubucquoi S, de Seze J, Dussart P, Vermersch $M$, et al. Characterization of discriminant human brain antigenic targets in neuropsychiatric systemic lupus erythematosus using an immunoproteomic approach. Arthritis and rheumatism. 2007;56(10):3420-32. doi: 10.1002/art.22863. PubMed PMID: 17907141.

132. Chai Z, Sarcevic B, Mawson A, Toh BH. SET-related cell division autoantigen-1 (CDA1) arrests cell growth. J Biol Chem. 2001;276(36):33665-74. Epub 2001/06/08. doi: 10.1074/jbc.M007681200 M007681200 [pii]. PubMed PMID: 11395479.

133. Hwang HM, Heo CK, Lee HJ, Kwak SS, Lim WH, Yoo JS, et al. Identification of anti-SF3B1 autoantibody as a diagnostic marker in patients with hepatocellular carcinoma. Journal of translational medicine. 2018;16(1):177. doi: 10.1186/s12967-018-1546-z. PubMed PMID: 29954402; PubMed Central PMCID: PMCPMC6025833.

134. Hosono Y, Nakashima R, Serada S, Murakami K, Imura Y, Yoshifuji H, et al. Splicing factor proline/glutamine-rich is a novel autoantigen of dermatomyositis and associated with anti-melanoma differentiation-associated gene 5 antibody. Journal of autoimmunity. 2017;77:116-22. Epub 2016/12/07. doi: 10.1016/j.jaut.2016.11.006. PubMed PMID: 27919567.

135. Hof D, Cheung K, de Rooij DJ, van den Hoogen FH, Pruijn GJ, van Venrooij WJ, et al. Autoantibodies specific for apoptotic U1-70K are superior serological markers for mixed connective tissue disease. Arthritis Res Ther. 2005;7(2):R302-9. Epub 2005/03/04. doi: ar1490 [pii]

10.1186/ar1490 [doi]. PubMed PMID: 15743477; PubMed Central PMCID: PMC1065328.

136. Yamamoto AM, Amoura Z, Johannet C, Jeronimo AL, Campos H, Koutouzov S, et al. Quantitative radioligand assays using de novo-synthesized recombinant autoantigens in connective tissue diseases: new tools to approach the pathogenic significance of anti-RNP antibodies in rheumatic diseases. Arthritis and rheumatism. 2000;43(3):689-98. Epub 2000/03/23. doi: 10.1002/1529-0131(200003)43:3<689::aid-anr27>3.0.co;2-u. PubMed PMID: 10728764.

137. Mimori T, Hinterberger M, Pettersson I, Steitz JA. Autoantibodies to the U2 small nuclear ribonucleoprotein in a patient with scleroderma-polymyositis overlap syndrome. The Journal of biological chemistry. 1984;259(1):560-5. PubMed PMID: 6231285.

138. Brahms H, Raymackers J, Union A, de Keyser F, Meheus L, Luhrmann R. The C-terminal RG dipeptide repeats of the spliceosomal Sm proteins D1 and D3 contain symmetrical dimethylarginines, which form a major B-cell epitope for anti-Sm autoantibodies. The Journal of biological chemistry. 2000;275(22):17122-9. doi: 10.1074/jbc.M000300200. PubMed PMID: 10747894.

139. McClain MT, Ramsland PA, Kaufman KM, James JA. Anti-sm autoantibodies in systemic lupus target highly basic surface structures of complexed spliceosomal autoantigens. Journal of immunology (Baltimore, Md : 1950). 2002;168(4):2054-62. PubMed PMID: 11823543.

140. Satoh M, Chan JY, Ross SJ, Ceribelli A, Cavazzana I, Franceschini F, et al. Autoantibodies to survival of motor neuron complex in patients with polymyositis: immunoprecipitation of $D, E, F$, and $G$ proteins without other components of small nuclear ribonucleoproteins. Arthritis and rheumatism. 2011;63(7):1972-8. Epub 2011/03/23. doi: 10.1002/art.30349. PubMed PMID: 21425128; PubMed Central PMCID: PMCPMC3123691. 
141. Garbarz M, Dhermy D, Bournier O, Bezeaud A, Boivin P. Anti-spectrin in sera containing smooth muscle autoantibodies from patients with chronic active hepatitis. Clinical and experimental immunology. 1981;43(1):87-93. Epub 1981/01/01. PubMed PMID: 6788413; PubMed Central PMCID: PMC1537121.

142. Imai H, Chan EK, Kiyosawa K, Fu XD, Tan EM. Novel nuclear autoantigen with splicing factor motifs identified with antibody from hepatocellular carcinoma. The Journal of clinical investigation. 1993;92(5):241926. doi: 10.1172/JCI116848. PubMed PMID: 8227358; PubMed Central PMCID: PMCPMC288425.

143. Yang Q, Qin J, Sun G, Qiu C, Jiang D, Ye H, et al. Discovery and Validation of Serum Autoantibodies Against Tumor-Associated Antigens as Biomarkers in Gastric Adenocarcinoma Based on the Focused Protein Arrays. Clin Transl Gastroenterol. 2020;12(1):e00284. Epub 2020/12/22. doi: 10.14309/ctg.0000000000000284. PubMed PMID: 33346593; PubMed Central PMCID: PMCPMC7752677.

144. Gordon P, Khamashta MA, Rosenthal E, Simpson JM, Sharland G, Brucato A, et al. Anti-52 kDa Ro, anti$60 \mathrm{kDa}$ Ro, and anti-La antibody profiles in neonatal lupus. J Rheumatol. 2004;31(12):2480-7. Epub 2004/12/01. doi: 0315162X-31-2480 [pii]. PubMed PMID: 15570655.

145. Cortini A, Bembich S, Marson L, Cocco E, Edomi P. Identification of novel non-myelin biomarkers in multiple sclerosis using an improved phage-display approach. PloS one. 2019;14(12):e0226162. Epub 2019/12/06. doi: 10.1371/journal.pone.0226162. PubMed PMID: 31805175; PubMed Central PMCID: PMCPMC6894809.

146. Niland B, Miklossy G, Banki K, Biddison WE, Casciola-Rosen L, Rosen A, et al. Cleavage of transaldolase by granzyme $B$ causes the loss of enzymatic activity with retention of antigenicity for multiple sclerosis patients. Journal of immunology (Baltimore, Md : 1950). 2010;184(7):4025-32. Epub 2010/03/03. doi: 10.4049/jimmunol.0804174. PubMed PMID: 20194725; PubMed Central PMCID: PMCPMC3117466.

147. Muto M, Mori M, Hiwasa T, Takiguchi M, Iwadate $Y$, Uzawa A, et al. Novel serum autoantibodies against talin1 in multiple sclerosis: Possible pathogenetic roles of the antibodies. Journal of neuroimmunology. 2015;284:30-6. Epub 2015/05/31. doi: 10.1016/j.jneuroim.2015.05.005. PubMed PMID: 26025055.

148. Mariampillai K, Granger B, Amelin D, Guiguet M, Hachulla E, Maurier F, et al. Development of a New Classification System for Idiopathic Inflammatory Myopathies Based on Clinical Manifestations and MyositisSpecific Autoantibodies. JAMA neurology. 2018;75(12):1528-37. Epub 2018/09/13. doi: 10.1001/jamaneurol.2018.2598. PubMed PMID: 30208379; PubMed Central PMCID: PMCPMC6583199.

149. Geng X, Biancone L, Dai HH, Lin JJ, Yoshizaki N, Dasgupta A, et al. Tropomyosin isoforms in intestinal mucosa: production of autoantibodies to tropomyosin isoforms in ulcerative colitis. Gastroenterology. 1998;114(5):912-22. PubMed PMID: 9558279.

150. Mahesh SP, Li Z, Buggage R, Mor F, Cohen IR, Chew EY, et al. Alpha tropomyosin as a self-antigen in patients with Behcet's disease. Clinical and experimental immunology. 2005;140(2):368-75. doi: 10.1111/j.13652249.2005.02760.x. PubMed PMID: 15807864; PubMed Central PMCID: PMCPMC1809367.

151. Kimura A, Sakurai T, Yamada M, Koumura A, Hayashi Y, Tanaka Y, et al. Anti-endothelial cell antibodies in patients with cerebral small vessel disease. Curr Neurovasc Res. 2012;9(4):296-301. PubMed PMID: 23030505. 152. Lorenz K, Beck S, Keilani MM, Wasielica-Poslednik J, Pfeiffer N, Grus FH. Course of serum autoantibodies in patients after acute angle-closure glaucoma attack. Clinical \& experimental ophthalmology. 2017;45(3):2807. Epub 2016/10/21. doi: 10.1111/ceo.12864. PubMed PMID: 27758063.

153. Zhao X, Cheng Y, Gan Y, Jia R, Zhu L, Sun X. Anti-tubulin-alpha-1C autoantibody in systemic lupus erythematosus: a novel indicator of disease activity and vasculitis manifestations. Clinical rheumatology. 2018;37(5):1229-37. doi: 10.1007/s10067-018-4024-3. PubMed PMID: 29427009.

154. Matthes T, Wolff A, Soubiran P, Gros F, Dighiero G. Antitubulin antibodies. II. Natural autoantibodies and induced antibodies recognize different epitopes on the tubulin molecule. Journal of immunology (Baltimore, Md : 1950). 1988;141(9):3135-41. PubMed PMID: 2459243.

155. Kimura A, Yoshikura N, Koumura A, Hayashi Y, Kobayashi Y, Kobayashi I, et al. Identification of target antigens of naturally occurring autoantibodies in cerebrospinal fluid. Journal of proteomics. 2015;128:450-7. Epub 2015/05/17. doi: 10.1016/j.jprot.2015.05.005. PubMed PMID: 25979775. 
156. Prasannan L, Misek DE, Hinderer R, Michon J, Geiger JD, Hanash SM. Identification of beta-tubulin isoforms as tumor antigens in neuroblastoma. Clinical cancer research : an official journal of the American Association for Cancer Research. 2000;6(10):3949-56. PubMed PMID: 11051243.

157. Stubbs EB, Jr., Fisher MA, Siegel GJ. Anti-tubulin antibodies in a sensorimotor neuropathy patient alter tubulin polymerization. Acta neuropathologica. 1998;95(3):302-5. Epub 1998/05/30. doi: 10.1007/s004010050802. PubMed PMID: 9542597.

158. Muro Y, Ogawa Y, Kato Y, Hagiwara M. Autoantibody to thioredoxin reductase in an ovarian cancer patient. Biochemical and biophysical research communications. 1998;242(2):267-71. Epub 1998/02/03. doi: 10.1006/bbrc.1997.7914. PubMed PMID: 9446782.

159. Betteridge ZE, Gunawardena H, Chinoy H, North J, Ollier WE, Cooper RG, et al. Clinical and human leucocyte antigen class II haplotype associations of autoantibodies to small ubiquitin-like modifier enzyme, a dermatomyositis-specific autoantigen target, in UK Caucasian adult-onset myositis. Annals of the rheumatic diseases. 2009;68(10):1621-5. doi: 10.1136/ard.2008.097162. PubMed PMID: 18930994.

160. Miyachi K, Hosaka H, Nakamura N, Miyakawa H, Mimori T, Shibata M, et al. Anti-p97/VCP antibodies: an autoantibody marker for a subset of primary biliary cirrhosis patients with milder disease? Scand J Immunol. 2006;63(5):376-82. doi: 10.1111/j.1365-3083.2006.01747.x. PubMed PMID: 16640662.

161. Bang H, Egerer K, Gauliard A, Luthke K, Rudolph PE, Fredenhagen G, et al. Mutation and citrullination modifies vimentin to a novel autoantigen for rheumatoid arthritis. Arthritis Rheum. 2007;56(8):2503-11. Epub 2007/08/01. doi: 10.1002/art.22817 [doi]. PubMed PMID: 17665451.

162. Paley EL, Alexandrova N, Smelansky L. Tryptophanyl-tRNA synthetase as a human autoantigen. Immunology letters. 1995;48(3):201-7. doi: 10.1016/0165-2478(95)02469-7. PubMed PMID: 8867852.

163. Wen J, Yaneva M. Mapping of epitopes on the $86 \mathrm{kDa}$ subunit of the Ku autoantigen. Mol Immunol. 1990;27(10):973-80. Epub 1990/10/01. PubMed PMID: 1700287.

164. Hoa S, Hudson M, Troyanov Y, Proudman S, Walker J, Stevens W, et al. Single-specificity anti-Ku antibodies in an international cohort of 2140 systemic sclerosis subjects: clinical associations. Medicine (Baltimore). 2016;95(35):e4713. doi: 10.1097/MD.0000000000004713. PubMed PMID: 27583908; PubMed Central PMCID: PMCPMC5008592 Montreal Rheumatology Program Abbvie educational grant. MH is funded by the Fonds de la recherche en Sante du Quebec. NN holds an NHMRC research fellowship (APP1071735). SA is funded by the NIH/NIAMS K23AR061436. MDM is funded by the NIH/NIAMS AR055258. The authors report no conflicts of interest.

165. Mahler M, Miller FW, Fritzler MJ. Idiopathic inflammatory myopathies and the anti-synthetase syndrome: a comprehensive review. Autoimmunity reviews. 2014;13(4-5):367-71. Epub 2014/01/16. doi: 10.1016/j.autrev.2014.01.022. PubMed PMID: 24424190; PubMed Central PMCID: PMCPMC3970575.

166. Kistner A, Bigler MB, Glatz K, Egli SB, Baldin FS, Marquardsen FA, et al. Characteristics of autoantibodies targeting 14-3-3 proteins and their association with clinical features in newly diagnosed giant cell arteritis. Rheumatology (Oxford, England). 2017;56(5):829-34. doi: 10.1093/rheumatology/kew469. PubMed PMID: 28064210.

167. van Beers-Tas MH, Marotta A, Boers M, Maksymowych WP, van Schaardenburg D. A prospective cohort study of 14-3-3eta in ACPA and/or RF-positive patients with arthralgia. Arthritis research \& therapy. 2016;18:76. doi: 10.1186/s13075-016-0975-4. PubMed PMID: 27037016; PubMed Central PMCID: PMCPMC4818496.

168. Qiu J, Choi G, Li L, Wang H, Pitteri SJ, Pereira-Faca SR, et al. Occurrence of autoantibodies to annexin I, 14-3-3 theta and LAMR1 in prediagnostic lung cancer sera. Journal of clinical oncology : official journal of the American Society of Clinical Oncology. 2008;26(31):5060-6. doi: 10.1200/JCO.2008.16.2388. PubMed PMID: 18794547; PubMed Central PMCID: PMCPMC2652098.

169. Chakravarti R, Gupta K, Swain M, Willard B, Scholtz J, Svensson LG, et al. 14-3-3 in Thoracic Aortic Aneurysms: Identification of a Novel Autoantigen in Large Vessel Vasculitis. Arthritis \& rheumatology (Hoboken, NJ). 2015;67(7):1913-21. doi: 10.1002/art.39130. PubMed PMID: 25917817; PubMed Central PMCID: PMCPMC4624269.

170. Teitsma XM, Devenport J, Jacobs JWG, Petho-Schramm A, Borm MEA, Budde P, et al. Comprehensive exploratory autoantibody profiling in patients with early rheumatoid arthritis treated with methotrexate or 
bioRxiv preprint doi: https://doi.org/10.1101/2021.04.05.438500; this version posted April 6, 2021. The copyright holder for this preprint (which was not certified by peer review) is the author/funder, who has granted bioRxiv a license to display the preprint in perpetuity. It is made available under aCC-BY 4.0 International license.

tocilizumab. PloS one. 2020;15(12):e0241189. doi: 10.1371/journal.pone.0241189. PubMed PMID: 33301475; PubMed Central PMCID: PMCPMC7728181. 